Cornell Law Library

Scholarship@Cornell Law: A Digital Repository

Cornell Law Faculty Publications

Faculty Scholarship

$10-1-2003$

\title{
Constitutional Existence Conditions and Judicial Review
}

Michael C. Dorf

Cornell Law School, michaeldorf@cornell.edu

Matthew D. Adler

University of Pennsylvania Law School, madler@law.upenn.edu

Follow this and additional works at: http://scholarship.law.cornell.edu/facpub

Part of the Constitutional Law Commons

\section{Recommended Citation}

Dorf, Michael C. and Adler, Matthew D., "Constitutional Existence Conditions and Judicial Review" (2003). Cornell Law Faculty Publications. Paper 84.

http://scholarship.law.cornell.edu/facpub/84

This Article is brought to you for free and open access by the Faculty Scholarship at Scholarship@Cornell Law: A Digital Repository. It has been accepted for inclusion in Cornell Law Faculty Publications by an authorized administrator of Scholarship@Cornell Law: A Digital Repository. For more information, please contact jmp8@cornell.edu. 
Citation: 89 Va. L. Rev. 2003

Content downloaded/printed from HeinOnline (http://heinonline.org) Mon Dec 8 20:18:50 2008

-- Your use of this HeinOnline PDF indicates your acceptance of HeinOnline's Terms and Conditions of the license agreement availalbe at: http://heinonline.org/HOL/License

-- The search text of this PDF is generated from uncorrected OCR text.

-- To obtain permission to use this article beyond the scope of your HeinOnline license, please use:

https://www.copyright.com/ccc/basicSearch.do?operation=go\&searchType=0 \&lastSearch $=$ simple\&all $=$ on\&titleOrStdNo $=0042-6601$ 


\title{
VIRGINIA LAW REVIEW
}

\begin{tabular}{lll}
\hline \hline VOLUME 89 & OCTOBER 2003 & NUMBER 6 \\
\hline
\end{tabular}

\section{ARTICLES}

\section{CONSTITUTIONAL EXISTENCE CONDITIONS AND JUDICIAL REVIEW}

\author{
Matthew D. Adler ${ }^{*}$ and Michael C. Dorf ${ }^{* *}$
}

INTRODUCTION: THE IMPOSSIBILITY OF A WHOLLY

EXTRAJUDICIAL CONSTITUTION

I. EXISTENCE CONDITIONS AND APPLICATION CONDITIONS:

THE FRAMEWORK

A. Existence Conditions, Application Conditions, and the

Inevitability of Constitutional Enforcement..................... 1117

B. Distinguishing Application from Existence Conditions... 1129

II. PARSing THE CONSTITUTION FOR EXISTENCE CONDITIONS

AND APPLICATION CONDITIONS............................................... 1136

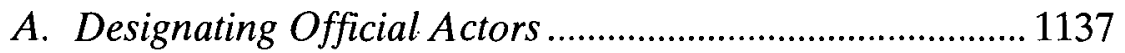

B. Mechanisms of Lawmaking.......................................... 1145

C. Subject-Matter Limits...................................................... 1150

D. Individual Rights ...................................................... 1161

III. UNDERENFORCEMENT OF EXISTENCE CONDITIONS ..............1172

A. Enrolled Bill Doctrine........................................................ 1172

B. The Political Question Doctrine ........................................ 1181

C. Rational Basis Review.................................................... 1188

* Professor of Law, University of Pennsylvania Law School.

** Professor of Law, Columbia University School of Law. For comments, suggestions and helpful discussions, the authors thank Larry Alexander, Mitchell Berman, William Buzbee, Sherry Colb, Barry Cushman, Christopher Eisgruber, John Hart Ely, Leslie Green, Kent Greenawalt, John Harrison, Kenneth Himma, Henry Monaghan, Gerald Neuman, Richard Pildes, Robert Schapiro, Anthony Sebok, Jonathan Siegel, Peter Strauss, Adrian Vermeule, Jeremy Waldron, Jeremy Webber, Louise Weinberg, Robin West, Kenji Yoshino, and Benjamin Zipursky. Scott P. Martin provided thorough and expert research assistance. 
D. The Court as Constitutional Legislator

E. Congressional Control ........................................................ 1197

\title{
INTRODUCTION: THE IMPOSSIBILITY OF A WHOLLY EXTRAJUDICIAL CONSTITUTION
}

\begin{abstract}
CRITICS of Marbury v. Madison have long complained that judicial review frustrates majoritarian democracy. ${ }^{2}$ In addition, critics sometimes complain that the Constitution's text does not en-
\end{abstract} tail judicial review of federal legislation. ${ }^{3}$ In Marbury, Chief Justice John Marshall invokes the judicial oath of office in support of judicial review, ${ }^{4}$ but the oath does not distinguish judges from other public officials who also swear fealty to the Constitution. Nor do Marshall's other arguments, such as the possibility of clear constitutional violation by the legislature, ${ }^{5}$ justify privileging judicial interpretation. The opinion, for all its majesty, never squarely addresses the fundamental question of whose interpretation of the Constitution should prevail in cases of conflict. ${ }^{6}$ Both sorts of criticism - that a sound democratic constitution should not establish

\footnotetext{
' 5 U.S. (1 Cranch) 137 (1803).

${ }^{2}$ See, e.g., Alexander M. Bickel, The Least Dangerous Branch: The Supreme Court at the Bar of Politics 16-23 (2d ed. 1986); James B. Thayer, The Origin and Scope of the American Doctrine of Constitutional Law, 7 Harv. L. Rev. 129, 155-56 (1893).

The canonical statement of the point is found in William W. Van Alstyne, A Critical Guide to Marbury v. Madison, 1969 Duke L.J. 1, 22 (1969) ("It is clear ... that the supremacy clause itself cannot be the clear textual basis for a claim by the judiciary that this prerogative to determine repugnancy belongs to it.").

${ }^{4}$ Marbury, 5 U.S. (1 Cranch) at 180.

${ }^{5}$ See id. at 179.

${ }^{6}$ Marshall's best textual argument relies on the assignment to the judiciary, in Article III, of the power to hear "all Cases ... arising under this Constitution." See U.S. Const. art. III, $\$ 2$; Marbury, 5 U.S. (1 Cranch) at 178. Marshall declares the proposition that the courts might adjudicate a case arising under the Constitution without providing their own interpretation of the Constitution "too extravagant to be maintained." Id. at 179 . The point is a fair one, although one could certainly imagine that the federal courts might apply their own interpretation of the Constitution only as against contrary state interpretations, not contrary interpretations by Congress. Interestingly, one of the best arguments in the literature for finding a power of judicial review in the Constitution's text and structure relies on the role of the Supreme Court vis-à-vis state courts. See Herbert Wechsler, Toward Neutral Principles of Constitutional Law, 73 Harv. L. Rev. 1, 2-5 (1959) (arguing that the obligation of state courts to give effect to the Constitution per the Supremacy Clause entails a parallel obligation for the Supreme Court on appeal).
} 
judicial review and that the American Constitution is best read not to establish judicial review-can lead ultimately to calls for the complete abolition of judicial review, for " $[\mathrm{t}]$ aking the Constitution [a]way from the [c]ourts."

Ingredient in most forms of judicial review skepticism is the implicit claim that it would be possible for courts to accept the word of Congress as final on matters of constitutional interpretation. Once one acknowledges that courts have the duty to apply statutes and other nonconstitutional sources of law, however, it becomes difficult to understand how they could not exercise at least some version of the Marbury power. In short, it may be impossible to take the entire Constitution away from the courts.

If the calls for abolishing judicial review (either by constitutional amendment or by overruling Marbury) were heeded, federal courts would find themselves in a vexing position, as a schematic example illustrates. Suppose plaintiff Smith appears before federal judge Jones waving a piece of paper that appears to be a federal statute entitling Smith to a judgment against defendant Acme Manufacturing for Acme's alleged violation of Smith's rights as set forth in the purported federal statute. Before the judge can apply the statute she must be sure that the piece of paper in fact is a statute.

Suppose that, contra Marbury, the judge accepts the authoritative utterances of Congress as binding on matters of constitutional interpretation. Accordingly, Smith claims that the piece of paper granting him rights against Acme is an authoritative utterance of Congress. The judge cannot simply take Smith's word for it; she must ask whether Congress actually enacted the purported statute.

Identifying authoritative utterances of Congress involves a twostep process. First, the judge must identify Congress. ${ }^{8}$ Second, she must identify its authoritative utterances. The Constitution speaks to both steps. Congress is the body chosen by the process set forth

\footnotetext{
${ }^{7}$ Mark Tushnet, Taking the Constitution Away from the Courts (1999); see also Learned Hand, The Bill of Rights 56-77 (1958) (examining arguments for and against judicial review); Jeremy Waldron, Law and Disagreement 255-312 (1999) (arguing that popular demand for constitutional rights does not eliminate the countermajoritarian difficulty of judicial review).

${ }^{8}$ The Court must also identify the President-even if one thinks the Court should not choose the President. Cf. Bush v. Gore, 531 U.S. 98 (2000) (ending the Florida recount and effectively selecting Bush as President). See infra text accompanying note 64.
} 
in Article I, Sections 2 through 4 and the Seventeenth Amendment, rather than, say, a group of self-styled patriots meeting on a Washington, D.C. tennis court. And Congress's authoritative utterances are those that (at a minimum) satisfy the criteria for lawmaking set forth in Section 7 of Article I. ${ }^{9}$ With respect to the piece of paper that purports to grant Smith rights against Acme, the judge must ask whether the body designated as Congress by the Constitution enacted it in accordance with the procedures set forth in the Constitution. ${ }^{.0}$ In other words, even in a world in which judicial review were formally abolished, the courts would still be guided by their own, independent interpretation of the Constitution in identifying the authoritative utterances of Congress.

The hypothetical case of the putative statute is more than a mere curiosity. It reveals that the conception of judicial interpretation of the Constitution held by judicial review critics, as well as most judges, lawyers, and scholars, is too narrow. In the standard account, judicial review is a process in which courts decline to enforce acts of Congress or state laws when they run afoul of constitutional prohibitions. The Constitution, on this view, consists of a list of what we will call "application conditions" for legal norms. The power to interpret the Constitution is, in this standard account, the power to set aside a law in favor of a constitutional provision that overrides it.

Yet, much of the Constitution consists of what are more properly understood as what we will call "existence conditions"-for instance, the President is the person chosen by the process set forth in Article II and the Twelfth Amendment; a bill becomes a law upon passage by both houses of Congress and signature of the

\footnotetext{
${ }^{9}$ We say "at a minimum" because-as shall be argued at length belowconstitutional provisions other than Article I, $\S 7$ may also state existence conditions for federal statutes.

${ }^{10}$ Could the judicial review skeptic reply that courts need not identify Congress and its authoritative utterances, but can instead defer to any body claiming to be Congress as to whether it really is Congress and whether its directives really are statutes? This clearly is not a viable reply. First, multiple, competing bodies might claim to be Congress. A court in this situation could not decide the existence questions at hand-what body is Congress and which directives are statutes-by deferring to the self-styled Congress, because there would be multiple such claimants providing conflicting answers to these questions. Second, and more fundamentally, we fail to see what grounds-epistemic or otherwise-could possibly justify a judicial practice of deferring to any body claiming to be Congress as to what Congress and statutes really are.
} 
President; ${ }^{11}$ and treaties are effective upon ratification by a twothirds vote in the Senate. ${ }^{12}$ In order to apply ordinary, nonconstitutional law, courts must first identify the law. ${ }^{13}$ They cannot completely avoid doing so by deferring to Congress, since to defer to Congress is just to identify one kind of nonconstitutional law-a statute.

This Article will employ the distinction between application and existence conditions to clarify what is at stake in calls either to make the Constitution nonjusticiable or for courts to defer to other actors' interpretations of the Constitution, and to shed light on the role that various doctrines of judicial deference play in our constitutional culture. If a constitutional provision states an application condition, to say that the provision should be nonjusticiable is not especially problematic. Under Marbury, the courts possess the power to enforce application conditions, but we can readily imagine a world in which they do not. In such a world, a court would apply any duly enacted law, notwithstanding the fact that, according to its own best interpretation of the Constitution, the law runs afoul of a constitutional provision. In the counter-Marbury world, application conditions are not addressed to the courts, and so their interpretation of such conditions is simply irrelevant to adjudication.

If a constitutional provision states an existence condition, however, rendering that provision nonjusticiable raises conceptual difficulties. For in such circumstances a court's reading of the Constitution may entail that the putative law put before it is not a law at all. A court cannot know what law to apply without first interpreting the Constitution.

We do not, of course, contend that overturning or narrowing Marbury would make the Constitution disappear in a puff of logic.

\footnotetext{
${ }^{11}$ U.S. Const. art. I, $\$ 7$, cl. 2.

${ }^{12}$ Id. art. II, $\$ 2$, cl. 2.

${ }^{13}$ The jurisprudential literature sometimes uses the term "legal validity" equivalently to this Article's term "existence condition." See, e.g., H.L.A. Hart, The Concept of Law 107 ( $2 \mathrm{~d}$ ed. 1994) (arguing that the rule of recognition "provides criteria for the assessment of the validity of other rules; but it is also unlike [other rules] in that there is no rule providing criteria for the assessment of its own legal validity"); Robert S. Summers, Judge Richard Posner's Jurisprudence, 89 Mich. L. Rev. 1302, 1303 (1991) (reviewing Richard A. Posner, The Problems of Jurisprudence (1990) and defining legal validity as the "criteria [a] putative law must satisfy to be valid").
} 
Many of the Constitution's provisions may be read as stating application rather than existence conditions. ${ }^{14}$ Moreover, it is possible for a court to defer to other actors even as to existence conditions. For example, federal courts accept the decisions of state courts or Congress as to which of two rival factions is the legitimate government of a state. ${ }^{15}$ And state courts and lower federal courts accept the word of the United States Supreme Court as to the content of constitutional doctrine. But such decisions to defer to other actors with respect to existence conditions either should be based on the courts' readings of the Constitution itself, as is sometimes true when a court concludes that a case presents a nonjusticiable political question, ${ }^{16}$ or should be made on epistemic grounds-where the court concludes that some other actor has greater expertise with respect to the constitutional issue at hand. ${ }^{17}$ In either case, the decision to defer will itself need to be validated by constitutional criteria: In the foregoing examples, the state courts, Congress, and the Supreme Court would need to be identified according to the criteria set forth in the Constitution ${ }^{18}$ to distinguish them from impostors.

Evaluating calls to make all or part of the Constitution nonjusticiable as well as calls for judicial deference to elected officials (or

\footnotetext{
${ }^{14}$ See infra Part II.

${ }^{15}$ See Luther v. Borden, 48 U.S. (7 How.) 1 (1849) (finding that federal courts lack the authority to adjudicate between two opposing factions, each of which claims to constitute the legitimate government of a state); id. at 40 ("Upon such a question the courts of the United States are bound to follow the decisions of the State tribunals ...."); id. at 42 ("Under [the Guaranty Clause] it rests with Congress to decide what government is the established one in a State."):

${ }^{16}$ See, e.g., Baker v. Carr, 369 U.S. 186, 209 (1962) ("We hold that the claim pleaded here neither rests upon nor implicates the Guaranty Clause and that its justiciability is therefore not foreclosed by our decisions of cases involving that clause."); Luther, 48 U.S. ( 7 How.) at 42 (finding a claim based on the Guaranty Clause to be nonjusticiable); id. at 217 ("Prominent on the surface of any case held to involve a political question is found [inter alia] a textually demonstrable constitutional commitment of the issue to a coordinate political department ....").

${ }^{17}$ One thinks of the general argument for following rules and obeying authority. See Joseph Raz, The Authority of Law: Essays on Law and Morality 233-49 (1979); Frederick Schauer, Playing by the Rules: A Philosophical Examination of Rule-Based Decision-Making in Law and in Life (1991).

${ }^{18}$ For provisions identifying the Supreme Court, see U.S. Const. art. II, \& 2, cl. 2; Id. art. III, $\$ 1$ ("The judicial Power of the United States, shall be vested in one supreme Court ...."). For discussion of provisions identifying state courts and Congress, see infra Section II.A.
} 
others) in matters of constitutional interpretation would therefore appear to require some assessment of which provisions of the Constitution state existence conditions and which state application conditions. As we will argue below, much of the Constitution is best read as stating existence conditions.

Consider a separation-of-powers case like Clinton v. City of New York. ${ }^{19}$ At issue there (according to the majority) was whether Congress could grant the President the equivalent of a line-item veto. ${ }^{20}$ The Court said no. As in INS v. Chadha, which invalidated the legislative veto, ${ }^{21}$ in Clinton the Court held that, absent a permissible delegation of power, utterances of Congress and the Executive that did not precisely follow the terms of Article I, Section 7 lacked legal effect. ${ }^{22}$

Would overruling Marbury undercut Chadha and Clinton? It might. In each instance it is possible to treat the legislation authorizing the unorthodox lawmaking procedure as dispositive of the constitutional question. ${ }^{23}$ Even if the line-item veto and legislative veto do not appear to comport with Article I, Section 7, the statutes conferring these powers were enacted in conformity therewith, and those statutes can be given deference-either because the courts read the relevant constitutional provisions as making Congress authoritative with respect to them or because of a policy of deference on epistemic grounds.

But granting Congress deference will not always be a coherent solution to challenges to novel lawmaking procedures. Imagine, for example, a law enacted in conformity with Section 7 of Article I that purports to require a three-fifths majority in each house for all subsequent measures raising taxes and that further declares itself amendable only by a three-fifths majority in each house. Even in the counter-Marbury world, it seems clear that a federal court would have to engage in nondeferential constitutional reasoning in order to determine whether to treat this law as binding in the face

524 U.S. 417 (1998).

${ }^{20} \mathrm{Id}$. at $447-48$.

${ }^{21} 462$ U.S. 919 (1983).

${ }^{22}$ Clinton, 524 U.S. at $436-41$.

${ }^{27}$ Cf. Chadha, 462 U.S. at 980 (White, J., dissenting) ("The power to exercise a legislative veto is not the power to write new law without bicameral approval or Presidential consideration. The veto must be authorized by statute and may only negative what an Executive department or independent agency has proposed."). 
of a subsequent measure-enacted by simple majorities of both houses of Congress, signed by the President, and thus appearing to be an authoritative utterance of Congress-purporting to repeal it. The principle of deference to the authoritative utterances of Congress would still require the Court to decide the conditions, if any, under which one Congress can bind a subsequent one. Given that requirement, how much of a step do the rulings in Chadha and Clinton represent?

Cases like Chadha and Clinton are sometimes described as posing separation-of-powers issues, yet the Constitution contains no specifically-articulated separation-of-powers principle. ${ }^{24}$ Separation-of-powers cases arise when one or more government actors attempt to exercise powers that, it is argued, the Constitution lodges elsewhere. One can describe such cases as posing the question whether the courts will apply the allegedly unconstitutional legal norm, but it is no less plausible to see them as posing existence questions: Has a constitutionally empowered actor acted in a way that gives rise to binding legal norms in the first place?

If we view the Constitution's provisions governing the allocation of lawmaking authority as setting forth existence conditions, it is not at all clear why we should not regard many other provisions in the same way. Of course, the question posed by a case like United States $v$. Lopez ${ }^{25}$ could be described as whether the courts are required to apply the Gun Free School Zones Act. But Lopez might also be described as posing the question whether the Gun Free School Zones Act is an authoritative utterance of Congress or whether it is, in the language of the previous paragraph, an attempt by one actor-the federal government-to exercise a power that the Constitution allocates to the states.

Indeed, all constitutional provisions might be understood as setting forth existence conditions. Certainly that was the dominant understanding for much of American constitutional history. Expressing what had long been the canonical view, the Supreme Court stated in Norton v. Shelby County that "[a]n unconstitutional act is not a law; it confers no rights; it imposes no duties; it affords

${ }^{24}$ Some state constitutions do. See, e.g., Ala. Const. art. III, $\S 43$; Ill. Const. art. 2 , § I; Mich. Const. art. III, § 2; S.C. Const. art. I, § 8.

2.5 514 U.S. 549 (1995). 
no protection; it creates no office; it is, in legal contemplation, as inoperative as though it had never been passed."26 Even the wording of some constitutional rights provisions, such as the First Amendment -instructing Congress as to what laws it can and cannot make-suggests that rights are not, or certainly are not merely, shields or trumps that block otherwise lawful measures; they can also be understood as setting forth existence conditions for legislation.

We do not mean to suggest that it would be logically impossible for courts to treat rights provisions, federalism provisions, and even most separation-of-powers provisions as setting forth application rather than existence conditions. Our point is simply that the constitutional text does not itself expressly draw any such line. Nothing in the written Constitution suggests that the lawmaking conditions set forth in Section 7 of Article I are to be treated differently from the powers enumerated in Section 8 of Article I. As far as the text of the Constitution is concerned, each of these provisions appears to say what pronouncements, by whom, count as law. ${ }^{27}$ Given the wording of our Constitution, judicial power to "enforce" the Constitution in the limited sense of identifying the authoritative pronouncements by Congress that are to receive deference may be the proverbial camel's nose under the tent, opening a path to full-

\footnotetext{
${ }^{26} 118$ U.S. 425, 442 (1886).

${ }^{27}$ Most notably, the text of the Supremacy Clause draws no distinction between existence and application conditions with regard to nonconstitutional federal law, but rather suggests that all constitutional provisions fall into the first category-that a federal "law" which fails to be made "in pursuance" of the Constitution is no law at all and is therefore not binding on state actors. U.S. Const. art. VI, cl. 2 ("This Constitution, and the Laws of the United States which shall be made in Pursuance thereof ... shall be the supreme Law of the Land; and the Judges in every State shall be bound thereby, any Thing in the Constitution or Laws of any State to the Contrary notwithstanding."). The Clause's reference to state judges makes clear that they, along with federal actors, are bound by federal law. The Clause takes for granted that federal actors, including federal judges, are bound by the Constitution, and thus suggests-if we are to extrapolate from the Supremacy Clause in this way-that they are obliged to treat all constitutional conditions applicable to federal law as existence conditions. To be clear, however, we do not defend the proposition that every constitutional condition applicable to federal law is an existence condition. As indicated below, for example, the Takings Clause is probably best read as an application condition, and we discuss other provisions that appear to be application conditions throughout this Article.
} 
blown judicial review-at least absent some good reason for courts not to head down that path.

Of course, the judicial review skeptic has a good reason to try to minimize the circumstances in which courts prefer their own understandings of the Constitution to those of politically accountable actors: democracy. Furthermore, even though the constitutional text does not distinguish between existence and application conditions, there is a certain intuitive logic to regarding (for example) Article I, Section 7 as setting forth the former and the Bill of Rights (for example) as setting forth the latter-traditional understandings of judicial review notwithstanding. According to this intuition, judges cannot avoid enforcing those provisions of the Constitution that identify the procedure for legislation and perhaps those that demarcate Congress's powers, but they can decline to enforce provisions that merely express additional constraints on duly enacted and empowered statutes. On this view, a bill enacted by only one house of Congress is no law at all, while a duly enacted statute that prohibits flag burning in interstate commerce is a law that a court may or may not apply depending on whether it has more than a minimal power of judicial review, and depending on its substantive interpretation of the First Amendment.

In our view, the question whether a given constitutional provision states an existence condition or an application condition is itself a constitutional question, as an example illustrates. Suppose the Constitution contained a provision stating that "a duly enacted law that purports to exercise a power not granted to Congress by this Constitution is void, and the courts shall disregard it in its entirety." Such a provision would settle the question whether enumerated powers state existence or application conditions. In the absence of such a provision, the constitutional question is simply how to read the constitutional provisions we in fact have.

In sum, much (if not all) of the Constitution consists of existence conditions rather than application conditions. Existence conditions determine what counts as nonconstitutional law-for example, whether some utterance by a self-styled Congress is a genuine statute. An existence condition cannot be "underenforced" once courts are engaged in the task of adjudicating the nonconstitutional law whose existence depends on the condition. Once courts are engaged in that task, the existence condition is necessarily fully en- 
forced-although full judicial enforcement can take the form of deference to some other actor, on epistemic grounds or where the constitutional provision at hand is best read to require deference. Finally, the question whether a constitutional provision falls in the "existence" or "application" category is itself a question of constitutional law, to be resolved using text, history, structure, doctrine, and other ordinary sources of constitutional interpretation.

The balance of this Article will clarify and defend these claims. Part I will set the stage by elaborating the distinction between existence and application criteria in greater detail. Although a document (or in the case of an unwritten constitution, a set of practices) could be denoted "the constitution," even if it did not play the role of identifying nonconstitutional sources of law, we think that a constitution typically will perform this function. In a legal system in which the constitution does identify nonconstitutional sources of law, we will ask, what does it mean for a judge (or other actor) to "enforce" the constitution?

The judicial review skeptic and, for that matter, most constitutional lawyers typically think of constitutional enforcement as constraining government actors, but this is a narrow and misleading picture. A judge enforces the constitution, we will argue, simply if her decision is sensitive to her beliefs about what the constitution requires (at least in some respects). Even if she defers to experts (such as the national legislature) on constitutional matters, she will need to identify those experts in light of her preliminary beliefs about what the constitution requires, since those beliefs will be crucial in determining whether the purported experts are really experts on constitutional matters.

How much of the constitution the judge enforces will depend on how many and which of its provisions "constitute"-state existence conditions for-nonconstitutional law, or merely override it. Accordingly, Part II will ask how various provisions of the U.S. Constitution are best categorized. To what extent are provisions regarding separation of powers, federalism, and individual rights best conceptualized as existence conditions rather than application conditions? We will conclude that many of the most familiar constitutional provisions state existence conditions.

Part III will analyze and defuse apparent counterexamples to our thesis that existence conditions are fully enforced: the "en- 
rolled bill" doctrine (which apparently instructs courts to underenforce Article I, Section 7 itself); the political question doctrine; "rational basis review" under the Due Process and Equal Protection Clauses; and others. The key to defusing these examples is a point to which we have already alluded: that courts might have epistemic or nonepistemic grounds for deference to nonjudicial actors with respect to the interpretation of some existence condition. But does not the point that full enforcement includes, perhaps, a posture of deference render our "victory" over the advocates of underenforcement quite hollow? We think not. As Part III will explain, a nonjudicial actor is owed epistemic deference only if it really is expert with respect to the constitutional provision at hand. And nonepistemic considerations justify deference with respect to an existence condition only if those considerations bear upon the very meaning of that condition-only if they are "internal" to its interpretation. In many cases where scholars have argued for underenforcement, neither of these grounds for deference will obtain.

We will turn first to showing what would be involved in a wholesale rejection of Marbury. Given the actual U.S. Constitution, it turns out that such an effort would have to be Herculean, to say the least. In a sense quite different from the one intended by John Marshall, the judicial power "to say what the law is" ${ }^{28}$ literally entails judicial power to construe (some and maybe much of) the Constitution. ${ }^{29}$

\footnotetext{
${ }^{28}$ Marbury, 5 U.S. (1 Cranch) at 177.

${ }^{29}$ It might be asserted that Marshall did intend to advance the very claim we are advancing - that constitutional existence conditions are necessarily enforced. Although this is not the standard reading of Marbury's argument-the standard reading holds that the crucial feature of higher law is that it limits nonconstitutional law rather than defines it-there is some textual evidence for an alternative interpretation. For example, Marshall states his position in the following way: "A legislative act contrary to the constitution is not law." Id. This could be read to mean that constitutionality goes to a law's very existence. But, even thus interpreted, Marbury's argument differs from ours. For Marbury never suggests that constitutional law might be a hybrid, in some instances defining nonconstitutional law and in other instances merely constraining it. The crucial distinction between existence conditions and application conditions is never drawn. Thus Marbury's argument on this alternative reading is, to our minds, unpersuasive. Because any given constitutional provision might be merely an application condition, an argument that assumes the provision to be an existence condition and, therefore, necessarily judicially enforced, is unconvincing. We are nonetheless grateful to Professor Robin West for pressing us to recognize this alternative reading of Marbury.
} 
I. EXISTENCE CONDITIONS AND APPLICATION CONDITIONS: THE FRAMEWORK

\section{A. Existence Conditions, Application Conditions, and the Inevitability of Constitutional Enforcement}

In this Part, we delineate a distinction between two types of constitutional provisions: between what we call "existence conditions," and what we call "application conditions." This distinction (whatever the terms one uses to name it) has singular importance for judicial review, for the possibility of judicial underenforcement and even nonenforcement of the Constitution, and for constitutional law and theory more generally. Surprisingly, constitutional scholars have largely overlooked it.

Consider the following two scenarios:

Is this a statute? John Smith sues his employer, Acme Manufacturing, in federal district court, claiming a violation of the "Safe Workplaces Act" and seeking damages. A putative copy of the Act, including an explicit cause of action for employees injured as a result of employer violations, is appended to Smith's complaint. Acme moves to dismiss and argues that the "Safe Workplaces Act" is a figment of Smith's imagination: no such statute was ever enacted into law pursuant to Article I, Section 7 of the Constitution.

Does this statute violate the Takings Clause? The Wetlands Preservation Act, a real federal statute, prohibits "industrial development" on wetlands. The Secretary of the Interior sues Widget, Inc. in federal district court under the fines provision of the Act. Widget raises an "as applied" constitutional defense. It claims that application of the Act to its particular wetlands parcel violates the Takings Clause ${ }^{30}$ because that parcel has zero value except in industrial uses.

The constitutional provision at issue in the first lawsuit is, intuitively, an existence condition: Unless the "Safe Workplaces Act" really was promulgated in accordance with Article I, Section 7, no

\footnotetext{
${ }^{30}$ U.S. Const. amend. V.
} 
such statute exists. The constitutional provision at issue in the second lawsuit is, intuitively, an application condition: The Wetlands Preservation Act, if passed by both houses of Congress and signed by the President, does not (seemingly) become a legal nullity merely because certain applications of the statute deprive property owners of all economic value and are therefore takings. Relatedly, judicial "enforcement" of the Constitution, in Smith's case, is an unavoidable prelude to ordinary, nonconstitutional adjudication: If the statute on which Smith has predicated suit is not a statute at all, then (once that objection has been raised by Acme or, if appropriate, raised by the court sua sponte) the court should of course dismiss the suit, while if the objection is spurious and no other valid objections are raised, the court should permit Smith's action to proceed. The judge's ruling on Acme's motion is necessarily sensitive (if she is conscientious) to her beliefs about what Article I, Section 7 requires, for her view about the legal status of the "Safe Workplaces Act" should depend upon those constitutional beliefs. By contrast, constitutional "enforcement" in Widget's case is an optional supplement to ordinary, nonconstitutional adjudication." Imagine that the judge in this case, for some reason, views her role as deciding cases only in light of the totality of statutes and all other relevant nonconstitutional sources of law. She agrees with Professor Mark Tushnet that the Constitution should be "nonenforced." 32 Then she can, at least in this case, do just that. Nothing in the task of assessing the statutory validity of a fine, under the Wetlands Preservation Act, forces the judge to consider Widget's takings claim-or at least so it seems.

We will now make more precise the conceptual framework that motivates our (and, we hope, the reader's) intuition that Smith's and Widget's cases are quite different as regards the optionality of constitutional judicial enforcement. We begin by defining our terms to distinguish constitutional provisions that identify valid

\footnotetext{
${ }^{31}$ By saying that constitutional enforcement of an application condition is "optional," we mean that further argumentation is needed to show that such a condition should be enforced. Enforcement does not directly follow, as with existence conditions, from the very task of nonconstitutional adjudication. We do not mean to say that underenforcement of all or even some application conditions is actually the legally correct posture for courts in the U.S. system. For more on this issue, see infra text accompanying note 48 .
}

${ }^{32}$ See Tushnet, supra note 7. 
nonconstitutional legal norms-constitutional provisions the enforcement of which is entailed by the obligation to enforce those nonconstitutional legal norms-from constitutional provisions that limit the operation of, but do not play a role in identifying, nonconstitutional legal norms.

Existence Conditions and Application Conditions: A Definition

A constitutional provision states an "existence condition" for some category of nonconstitutional law (federal statute, federal common law, federal regulation, state law, and so forth) if it states a necessary condition for any proposition to fall within that category. ${ }^{33}$ A constitutional provision states an "application condition" for nonconstitutional law if the provision limits the legal force of a proposition of nonconstitutional law by some means other than vitiating the status of that proposition as law.

Consider once more the example of a federal statute. Of the infinity of normative propositions, a finite subset consists of federal statutes or parts of federal statutes. What is the legal test for the statutory status of some proposition? This test might take the simple form of a list of individually necessary and jointly sufficient conditions, or it might take a more complicated form. It might be a short test (for example, "a proposition is a federal statute if and only if it is enacted pursuant to Article I, Section 7 of the Constitution"), or it might be a longer test (for example, "a proposition is a federal statute if and only if it is thus enacted, falls within an enumerated power, satisfies all the provisions of Article I, Section 10,

\footnotetext{
${ }^{33}$ This definition might be too restrictive. The test for something to be a statute could take the form of a list of disjunctive conditions: Proposition $P$ is a statute if passed in accordance with Article I, $\S 7$, or if long accepted by courts as a statute, or .... In that case, Article I, \& 7 would not function as a necessary condition for a proposition to be a statute; it would function merely as a necessary element of one set of sufficient conditions. We do not pursue these complexities here because it seems that the provisions in the Constitution plausibly functioning as existence conditions would be necessary conditions for existence-at least if provisions are individuated in fairly standard ways. For example, the Commerce Clause itself is not a necessary condition for some utterance to be a federal law (since a proposition that exceeds the bounds of the Commerce Clause can still be a statute if it falls within, say, the Spending Clause or $\S 5$ of the Fourteenth Amendment), but the enumerated powers as a whole either consist of application conditions or comprise a necessary condition for some utterance to be a federal law.
} 
and is not so morally repugnant as to be void on those grounds"). This test might be wholly constitutional, or it might be partly extraconstitutional. ${ }^{34}$ Whatever the form, size, and status of the legal test for federal statutes, a constitutional provision is an existence condition for federal statutes if it functions as a necessary condition within that test. More generally, whatever the form, size, and status of the legal test for some given type of law (federal statute, federal regulation, state statute, state regulation, federal common law, and so forth), a constitutional provision is an existence condition for that type of law if no proposition can be law of that type unless the provision is satisfied.

As for the concept of an "application condition," we define this as a catch-all. How might a constitutional provision limit the legal force of, say, federal statutes without functioning as a statutory existence condition? The obvious example is a provision that grounds true "as-applied" constitutional rights: rights that prevent the application of valid statutes in certain situations, or to certain types of persons. ${ }^{35}$ Imagine that the following Veterans Protection Amendment is added to the Constitution: "No veteran who commits a crime as a result of a war injury may be punished for that crime." This Amendment creates a constitutional immunity that prevents the application of federal (and state) criminal statutes to certain otherwise-punishable activities by veterans; it does not void or nullify these statutes. It is also conceivable that constitutional provisions might limit, without nullifying, valid law through some mechanism other than "as-applied" challenges. (As a silly example, imagine an Eclipse Amendment that blocks any enforcement of

${ }^{34}$ The test would be partly extraconstitutional if, for example, the rule of recognition directly provided a partial definition of a statute but referred to the Constitution to complete the definition. On the rule of recognition, see Hart, supra note 13 , at $100-10$.

${ }^{35}$ Michael C. Dorf, Facial Challenges to State and Federal Statutes, 46 Stan. L. Rev. 235, 236 (1994) [hereinafter Dorf, Facial Challenges] (acknowledging that "a court may declare a statute unconstitutional in one of two manners ... [either] on its face, or ... as applied to a particular set of circumstances"); cf. Matthew D. Adler, Personal Rights and Rule-Dependence: Can the Two Coexist?, 6 Legal Theory 337, 345-49 (2000) [hereinafter Adler, Personal Rights] (conceding that genuine as-applied provisions can exist); Matthew D. Adler, Rights Against Rules: The Moral Structure of American Constitutional Law, 97 Mich. L. Rev. 1, 7-12 (1998) [hereinafter Adler, Rights Against Rules] (viewing many constitutional provisions as creating facial rather than as-applied rights). 
certain federal statutes during solar eclipses.) Although provisions grounding "as-applied" challenges are the paradigm case of constitutional provisions functioning as what we call "application" conditions-hence the name-in principle the category is broader than that.

Some further clarifications are in order. First, nothing in our distinction between existence and application conditions entails a textualist approach to constitutional interpretation or ontology. We use the term "constitutional provision" for stylistic reasons, but by this we simply mean some norm or principle or, more generally, some proposition of constitutional law. The set of true propositions of constitutional law may or may not map onto the set of sentences, or textual "provisions," set forth in the canonical text we know as the Constitution. The longstanding debates about constitutional interpretation-between textualists and nontextualists, originalists and nonoriginalists, moral readers and those who eschew moral reading $s^{36}$-are debates about the legal grounding for this propositional set: about the test for constitutionality. We do not mean to take a side in these familiar debates here, nor do we need to.

Second, our framework is not meant to be exhaustive: Some constitutional provisions might be neither existence conditions nor application conditions. Consider Article V, which states an existence condition for constitutional law itself, not for federal statutes or other sources of nonconstitutional law. ${ }^{37}$ Or consider the Oath Clause of Article VI, which imposes a duty to swear an oath on state and federal officials, and is neither (it seems) an existence condition nor an application condition. ${ }^{38}$ These provisions are unusual, though, because the central function of the U.S. Constitution is to constitute a federal government and to limit all governments in the U.S. system, both federal and state. Thus, leaving aside special

${ }^{36}$ See, e.g., Robert H. Bork, The Tempting of America: The Political Seduction of the Law (1990); Ronald Dworkin, Freedom's Law: The Moral Reading of the American Constitution (1996) [hereinafter Dworkin, Freedom's Law]; Paul Brest, The Misconceived Quest for the Original Understanding, 60 B.U. L. Rev. 204 (1980); Thomas C. Grey, Do We Have an Unwritten Constitution?, 27 Stan. L. Rev. 703 (1975); Richard S. Kay, Adherence to the Original Intentions in Constitutional Adjudication: Three Objections and Responses, 82 Nw. U. L. Rev. 226 (1988); Michael Moore, The Written Constitution and Interpretivism, 12 Harv. J.L. \& Pub. Pol'y 3 (1989).

${ }^{37}$ U.S. Const. art. V.

${ }^{38}$ Id. art. VI, cl. 3. 
cases like the Oath Clause, and leaving aside higher-order constitutional provisions such as Article $\mathrm{V}$ that help to identify the content of constitutional law itself, a constitutional provision generally will fall into the existence or application category: It will indeed "constrain" the actions of government officials and would-be officials, either by helping to define which utterances of theirs are legal utterances, or by providing an additional legal norm, an additional "source of law," that figures in the mix of legal considerations determining private citizens' ultimate legal rights, duties, privileges, and so forth.

Why do we make so much of the distinction between existence and application conditions? Our chief claim in this Article is that the distinction has much significance for the debate about judicial review. As already suggested, this distinction goes to the very possibility of judicial nonenforcement or underenforcement of the Constitution. Judicial nonenforcement or underenforcement of application conditions, however inadvisable, is a possible judicial practice; judicial nonenforcement or underenforcement of existence conditions is, as we will explain shortly, not possible. The point can be stated more precisely: $A$ judicial duty to take account of some type of law, in adjudicating cases, entails a duty to enforce constitutional provisions that state existence conditions for that type of law. By "enforce," here, we have in mind a broad understanding of judicial enforcement of the Constitution, not a narrower and more coercive picture associated with a certain category of constitutional litigation-(injunctive or declaratory) anticipatory litigation. ${ }^{39}$ A court enforces the Free Speech Clause ${ }^{40}$ when it enjoins a government official from implementing a law that infringes speech. It also enforces the Clause when it refuses to enter a sentence of conviction or some other judicial directive against a constitutional claimant whose statutory violation is predicated on his protected speech. Similarly, the Commerce Clause" is "enforced" both through judicial declarations "invalidating" statutes that exceed its boundaries and through judicial judgments for defendants sued by plaintiffs under statutes exceeding the Clause's boundaries. A

\footnotetext{
${ }^{39}$ Cf. Adler, Rights Against Rules, supra note 35, at 132-52 (discussing judicial enforcement in the narrower and more coercive sense).

${ }^{40}$ U.S. Const. amend. 1.

${ }^{41}$ Id. art. I, $§ 8$, cl. 3.
} 
judge "enforces" a constitutional provision if her decision is sensitive to her beliefs about what the provision requires-if the provision figures in her official deliberations.

Note that judicial enforcement of the Constitution in this broader sense, not in a narrower and more interventionist sense, is what occurred in Marbury itself: The Supreme Court "enforced" Article III by declining to issue the writ of mandamus sought by Marbury. We hardly mean to claim that ordinary, nonconstitutional adjudication entails a judicial power to issue injunctions or other judicial directives against government officials, imposing constitutional duties on them. Rather, we claim that the Constitution (insofar as it states existence conditions) inevitably figures in the deliberations of the conscientious judge who is engaged in nonconstitutional adjudication and who is legally cognizant of the sources of nonconstitutional law governed by these conditions. In this very basic sense she inevitably "enforces" the Constitution.

The argument for this claim is straightforward. If (1) the judge is under a legal duty to take account of some type of nonconstitutional law in reaching her decisions, ${ }^{42}$ then (2) she is under a legal

\footnotetext{
${ }^{42}$ Note that this duty may be delimited by procedural requirements. For example, Congress could probably require courts to hear claims arising under federal statutes and stipulate that a court should enter judgment for a plaintiff who advances a statutory claim, without determining whether the putative statute exists, if the defendant does not appear. In such a case, the court would adjudicate the statutory claim without enforcing-taking account of-the constitutional existence conditions for statutes. Procedural rules governing nonconstitutional adjudication cannot be so constraining, however, as to preclude judicial enforcement of relevant existence conditions in the typical run of cases, thereby circumventing limits on Congress's power to pick and choose among existence conditions. See infra Section III.E (arguing that Congress can determine which types of nonconstitutional law should play a role in adjudication, but that it lacks an additional power to waive the enforcement of constitutional existence conditions). Drawing the line between legitimate procedural rules and illegitimate congressional waivers of existence conditions is a difficult problem which we do not attempt to resolve here. To see the problem, imagine that Congress stipulates that courts should adjudicate claims under federal statutes, but that defendants who fail in their answer or in a pre-answer motion to raise an Article I, $\$ 7$ bicameralism objection to a complaint advancing a statutory claim shall be deemed to have forfeited the constitutional objection. Cf. Fed. R. Civ. P. 12(h)(1) (specifying that defenses based on Iack of personal jurisdiction, improper venue, insufficiency of process and insufficiency of service of process are waived if not raised in pre-answer motion or answer). This proceduraI rule would probably be acceptable, although the matter is hardly free from doubt. See Commodity Futures Trading Comm'n v. Schor, 478 U.S. 833, 850-51 (1986) (holding that parties cannot consent to have a non-Article III forum adjudicate a case that, absent consent, would have to be assigned to an Article III court, and thus
} 
duty to determine whether putative legal propositions of that type, advanced by the parties, really do have legal force. Yet this entails (3) a legal duty to determine whether these putative legal propositions satisfy the existence conditions stated by relevant constitutional provisions.

The assumptions that drive this argument are minimal. We do not presuppose an "inclusive" picture of adjudication: one where the judge must take account of all law, or even all nonconstitutional law. Imagine that Congress creates a "federal civil court" that is obliged to consider those and only those civil causes of actions predicated on federal statutes and to entertain only federal statutory defenses to those claims. The court would still need to enforce Article I, Section 7 to do its job. The same would be true if Congress were to create a "federal diversity court" empowered to consider only state common law causes of action and explicitly instructed by Congress to ignore federal statutory defenses: Insofar as the Constitution sets forth existence conditions for state law (for example, in the Guaranty Clause of Article IV, Section 4 and perhaps Article I, Section 10 and the Civil War Amendments), the "diversity court" would inevitably enforce those constitutional provisions.

By saying that judicial enforcement of existence conditions is "inevitable" or nonenforcement "impossible," we have in mind legal possibility, not physical or moral possibility or possibility in some other sense. A judge is not physically compelled to have constitutional existence conditions figure in her deliberations; it is empirically possible for her to decide cases based solely on her whims, tastes, or policy preferences. Nor is a judge morally compelled to enforce the Constitution: Insofar as the Constitution is unjust, it might be morally best for her to ignore it. Rather, our claim concerns legality. A legal duty to adjudicate will be a legal duty to take account of at least some (if not all) of the various types of legal

implying possible limits on congressional ability to condition adjudication of existence condition questions on party conduct). The doubts would become overwhelming if Congress were to stipulate that an Article I, $\$ 7$ bicameralism objection is forfeited if not raised within five minutes of the defendant's receiving the complaint (or in the case of a statutory defense, within five minutes of the plaintiff's receiving the answer), because, quite apart from any due process issue, the stipulation would be an impermissible effort by Congress to circumvent the limits posed by an existence condition. Needless to say, there are intermediate cases. 
propositions that govern a case. This legal duty (whatever its source) in turn entails a legal duty to enforce constitutional provisions that state existence conditions for those types of law the judge is bound to apply.

It bears emphasis that our claim about the inevitability or necessity of judicial enforcement is a conditional claim. We do not claim that all constitutional existence conditions necessarily come into play when a court engages in nonconstitutional adjudication. For, as already explained, Congress can limit the scope of nonconstitutional adjudication in the federal courts. Congress can surely instruct federal courts to ignore state law, and may well be able to instruct them to ignore various types of federal law as well. The claim is rather that, if Congress has instructed a court to entertain claims or defenses grounded in some type of nonconstitutional law, then a court must necessarily take account of constitutional existence conditions relevant to that type of law. This claim is conceptual, and thus a claim of necessity, but it is conditional rather than absolute..$^{43}$

Our argument rules out the wholesale nonenforcement of constitutional provisions. But, even more powerfully, it rules out underenforcement as well. Imagine that the Commerce Clause is indeed an existence condition for federal statutes, not merely an application condition, and is best understood to mean that the federal government may only regulate activities given interstate externalities, collective action problems, or other such "federalism failures" precluding effective state regulation. A court might be tempted to underenforce this provision, say, through a "rational basis" test: If Congress had a rational basis for thinking that state regulation would not be effective, a Commerce Clause challenge to the federal statute will be rejected. ${ }^{44}$ But if the Commerce Clause is truly an existence condition, this underenforcement posture is legally

\footnotetext{
${ }^{43}$ But if Congress can control federal court jurisdiction, why is it limited to all-ornothing choices with respect to various types of nonconstitutional law? Why can it not instruct a court to entertain claims or defenses arising under some type of nonconstitutional law, and to enforce some but not all of the existence conditions relevant to that type? This issue is considered at length below. See infra Section III.E.

${ }^{44}$ See United States v. Lopez, 514 U.S. 549, 603-15 (1995) (Souter, J., dissenting); Preseault v. ICC, 494 U.S. 1, 17 (1990); Hodel v. Va. Surface Mining \& Reclamation Ass'n, 452 U.S. 264, 276 (1981); Maryland v. Wirtz, 392 U.S. 183, 190 (1968) (quoting Katzenbach v. McClung, 379 U.S. 294, 303-04 (I964)).
} 
improper. For if the Commerce Clause is truly an existence condition, a proposition that may satisfy other tests for statutory status but fails to satisfy the Commerce Clause is no more a real federal statute than a bill that passes the House but not the Senate, or, for that matter, than the scribblings of a crackpot litigant. The judge who (1) believes that Congress had a rational basis for believing that federalism failures prevented effective state action, and thus for enacting the text relied upon by some litigant, but also (2) believes that federalism failures did not in fact prevent effective state action, is (on the hypothesis that he knows the Commerce Clause to be an existence condition) in the position of believing that the text lacks the legal force of a statute.

But what about constitutional doctrines, such as the political question doctrine, that do wholly preclude judicial enforcement and seemingly apply, or can apply, to existence as well as application conditions? And what about the widespread judicial use of "rational basis" tests and the like, again under provisions that quite plausibly concern the very existence of nonconstitutional law, not its application? These questions are entertained at length in Part III, where we consider putative counterexamples to the claim that constitutional provisions stating existence conditions are necessarily fully enforced. To anticipate the answers we develop there, we would note first that judicial deference on epistemic grounds to the judgments of nonjudicial actors is not underenforcement at all. If the court believes that Congress is expert and conscientious with respect to some constitutional provision $P$ stating an existence condition for federal statutes, and therefore takes as a full-fledged statute any proposition satisfying every other condition for statutory status, then the court's decision is sensitive to its beliefs about what $P$ requires: Congressional enactment of the text at issue functions as evidence, for the court, that $P$ is satisfied. ${ }^{45}$

The real puzzle for our view is judicial deference on nonepistemic grounds to the judgments of nonjudicial actors. Our answer here is that the Constitution may require courts to take as authori-

${ }^{45}$ On epistemic grounds for judicial deference, see Matthew D. Adler, Judicial Restraint in the Administrative State: Beyond the Countermajoritarian Difficulty, $145 \mathrm{U}$. Pa. L. Rev. 759, 804-05 (1997) [hereinafter Adler, Judicial Restraint]. On epistemic grounds for deference more generally, see Heidi M. Hurd, Challenging Authority, 100 Yale L.J. 1611 (1991). 
tative the judgment of some nonjudicial body that some existence criterion is satisfied. In effect, existence conditions can be institution-specific, or perspectival. For example, the test for whether a proposition is a statute inight be different for different actors: The Constitution might create one such test for the President, another for Congress, another for the Supreme Court, another for the lower federal courts, and so on. The correct test, for courts, might refer (in part) to the conscientious judgments of various nonjudicial actors. A court that, in conformity with this perspectival test, defers to the judgment of some nonjudicial actor is fully enforcing-not underenforcing - the test. Further, judicial application of perspectival constitutional tests for legality that refer courts to the decisions of other actors involves genuine constitutional analysis and reasoning as much as judicial application of nonperspectival tests. Imagine that the Constitution is best interpreted as instructing federal courts to defer to the highest state court in determining whether some proposition is state law. Federal courts will then need to determine whether the putative "state supreme court" that makes assertions about state law within some state is really the highest state court (for federal constitutional purposes) or an impostor. And if the federal courts decide to defer to Congress or some other actor in identifying state supreme courts, they will need to justify that decision on either epistemic or other, constitutional, grounds.

The argument for judicial review that we have just articulated and that we develop further in Part III is different from Marbury's. The central thrust of Marshall's argument-as the argument is generally understood-is that the Constitution is higher law, the source for a type of law that is supreme over other types. ${ }^{46}$ How could a court that considered nonsupreme law ignore paramount law? This argument, if sound, requires judicial enforcement of constitutional provisions stating application as well as existence conditions. To be sure, Marshall's language at various points suggests that he views all of the Constitution as stating existence rather than application conditions. ${ }^{47}$ But, once more, this is not our view-or at

\footnotetext{
${ }^{46}$ Marbury, 5 U.S. (1 Cranch) at 177.

${ }^{47}$ Id. ("[T] he theory of every ... government [with a written constitution] must be, that an act of the legislature, repugnant to the constitution, is void."); see supra note 29 (discussing this alternative reading of Marbury).
} 
least it does not follow from the status of the Constitution as law, higher law, or written law. A clause at the beginning of the Bill of Rights stating explicitly that these amendments did not serve to "nullify" or "void" inconsistent statutes would not render the Constitution incoherent.

We have discussed, at some length, the enforceability of existence conditions. What about the enforceability of application conditions? We do not mean to assert that judges may underenforce such provisions. The propriety of underenforcing application conditions implicates longstanding debates that we do not mean to enter. Judicial enforcement of application conditions is not an inevitable component of nonconstitutional adjudication, but it might still be legally mandated. For example, Article III and/or the Judiciary Acts might be read as requiring courts to ignore the litigation costs, democratic costs, legitimacy costs, and so forth that may attend constitutional litigation, and to fully enforce all constitutional provisions. Alternatively, it might be argued that both Article III and the statutes governing the federal courts are sufficiently openended to permit such "institutional" considerations to trigger genuine underenforcement ${ }^{48}$ of various constitutional application conditions. It is beyond the scope of this Article to take a position in this debate. Our point is rather that the debate is irrelevant to the enforceability of existence conditions. The considerations bearing on the enforcement of application conditions are just different from those bearing on the enforcement of existence conditions. However persuasive the case for underenforcement of application conditions might be, the case for full enforcement of provisions that determine which propositions have the status of nonconstitutional law remains compelling.

\footnotetext{
${ }^{48}$ By genuine underenforcement we mean judicial cognizance of litigation costs, democratic costs, legitimacy costs, and other such considerations even where these do not bear upon the best interpretation of the constitutional provision at hand-even where they are "external," not "internal," to constitutional interpretation. For more on this distinction between the permissible role of institutional considerations with respect to existence conditions, and their'permissible role with respect to application conditions, see infra text accompanying notes $215-21$.
} 


\section{B. Distinguishing Application from Existence Conditions}

Does a constitution necessarily contain existence conditions for laws within the legal system that it governs? The answer to that question depends on the meaning of "constitution"-an issue we have not pursued at length here. If, for example, a "constitution" is a set of legally supreme norms grounded in a written document, then in principle constitutions can consist entirely of application conditions. On this view, a written "Declaration of Rights" that articulated Dworkinian rights functioning as trumps on legislation, ${ }^{49}$ and that was unamendable through ordinary legislative processes, would be a full-fledged constitution that judges within the system could nonetheless ignore in determining what had the status of nonconstitutional law.

Does the U.S. Constitution contain existence conditions? Surely it does. First, there are provisions Americans intuitively understand as (partly) constituting the difference between law and nonlaw-for example, Article I, Section 7, a provision we have invoked several times. Second, and more generally, Americans think of the Constitution as constituting at least one government within the U.S. legal system-the federal government. The Constitution, transparently, creates key federal institutions: Congress, a President, the Supreme Court. Even if the test for federal law were otherwise wholly extraconstitutional-directly stated in the rule of recognition ${ }^{50}$ say-presumably that test would refer to these institutions. If, instead, the test said "a proposition is a law if enacted in a certain way by Kongress [not identical to the Congress created by the Constitution]," then this "constitutive" understanding of the Constitution would be exploded.

Thus, at least some of the Constitution sets forth existence conditions for federal law. That much is clear. This claim alone has considerable importance, for it undermines the possibility of wholesale judicial nonenforcement of the Constitution. Assume that Article I, Sections 1 though 7 and Article II, Section 1 state existence conditions for federal statutes, while Article I, Sections 8

\footnotetext{
${ }^{49}$ For a discussion of the concept of rights as "trumps," see Ronald Dworkin, Taking Rights Seriously (1978) [hereinafter Dworkin, Taking Rights Seriously]; Ronald Dworkin, Rights as Trumps, in Theories of Rights 153 (Jeremy Waldron ed., 1984).

${ }^{50}$ See text accompanying infra note 54 .
} 
and 9 and the Bill of Rights state application conditions. Then judges engaged in ordinary adjudication and bound to take account of federal statutes are (without more) free to ignore the enumerated powers clauses of the Constitution and the Bill of Rights, but are not free to ignore the entire document.

But we intend to do more than show that some of the Constitution states existence conditions for federal law. The claim we defend in Part II is that much of the Constitution consists of existence conditions for federal and even state law, including Article I, Section 8; the separation-of-powers provisions; and even much of the Bill of Rights-provisions that are now widely viewed as underenforced, in line with numerous scholarly proposals to that effect. ${ }^{51}$ Our claim, it should be stressed, is not that the Constitution necessarily or in fact consists entirely of existence conditions. ${ }^{52}$ Nor is it that the existence conditions for law within the U.S. system are entirely set forth in the Constitution. This is clearly not the case with regard to state law, and it may not be true for federal law either. Our claim is substantive rather than conceptual-grounded in substantive arguments about particular clauses, not in the putatively necessary features of any provision in any constitution or in the U.S. Consitution-and should not be conflated with the claim that the whole test for legality is contained in the Constitution. The whole test for legality, in the U.S. system, is not contained in the Constitution, but the function of much, if not all, of the Constitution is to contribute to that test. ${ }^{53}$

But how can one determine whether a given provision in the Constitution states an existence condition or an application condition (or something else)? Answering that question requires us to address a deep methodological issue: Is the characterization of a

\footnotetext{
${ }^{51}$ See sources cited infra note 183 .

${ }^{52}$ Consider, in this regard, the Oath Clause in Article VI, or the Thirteenth Amendment insofar as it prohibits private persons from enslaving others.

${ }^{53}$ We do not mean to suggest that the Constitution is any part of the ultimate test for legality in the American legal system. The positivist would insist that it is not-that the ultimate test consists in the rule of recognition, which directly or indirectly refers to the Constitution. See generally Kent Greenawalt, The Rule of Recognition and the Constitution, 85 Mich. L. Rev. 621, 622 (1987) (arguing "that the rule of recognition [includes] a number of standards and [is] quite complex, omitting some of the federal Constitution while including aspects of state law and interpretive standards used by judges").
} 
constitutional provision as an existence versus application condition itself a question of constitutional law? Or is that question extraconstitutional?

To address that issue, we must briefly detour away from constitutional theory and into analytical jurisprudence. The role of the Constitution in defining law cannot be wholly separated from yet more basic and general questions about the nature of law. The dominant, contemporary position in analytical jurisprudence is positivism..$^{54}$ The positivist says (roughly) that the ultimate criterion of legality in any legal system is a "rule of recognition": a rule that is followed by officials and is taken by them to have normative force, and that directly, or by incorporation, grounds all legal rights, duties, privileges, and so forth. Any condition for legality is either stated directly in the rule of recognition, or is stated in some other rule whose role in providing legality conditions itself derives from the rule of recognition.

How would the positivist answer the methodological question with which we are now grappling: Is the status of a constitutional provision as an existence condition settled by the Constitution itself, or rather extraconstitutionally? The positivist would answer that question by looking to official practice: the practice constitutive of the rule of recognition. Two different practices are possible. Officials might follow a "thick" rule that incorporates the Constitution, but itself determines the characterization of constitutional provisions. One example is as follows:

A Thick Rule of Recognition

- A proposition constitutes a federal statute if and only if it satisfies the procedures for promulgating statutes set forth in the Constitution, that is, the procedures set forth in Article I, Section 7 .

- Duly promulgated statutes that violate other constitutional provisions are not void, but their enforcement can be limited by judges.

\footnotetext{
${ }^{54}$ See, e.g., Jules L. Coleman, The Practice of Principle: In Defence of a Pragmatist Approach to Legal Theory (2001); Hart, supra note 13; Raz, supra note 17.
} 
In effect, this thick rule itself determines that Article I, Section 7, plus the provisions defining the actors relevant for that Section (Congress and the President), but not the rest of the Constitution, state existence conditions for federal statutes. However, it is also possible for officials to follow a "thin" rule of recognition-one that incorporates the Constitution more thoroughly. The content of the thin rule would amount to something like the following:

A Thin Rule of Recognition

- A proposition constitutes a law of some type (such as a federal statute, a federal regulation, or a state statute) if and only if it satisfies the criteria for legality set forth in the rule of recognition itself, the Constitution, and all other rules derivative of these.

- Whether a constitutional provision sets forth an existence condition for some type of law is itself a constitutional question.

Both the thin and the thick rules are possibilities, but which is the actual rule within the U.S. system? This is an empirical question, which cannot definitively be settled here. It seems reasonably clear, however, that officials within the U.S. system follow a thin, rather than a thick, rule. The issue can be framed thus: If the ordinary, conscientious official were to believe that the Constitution purported to nullify a law that failed to satisfy some constitutional provision, would the official then treat the law as a nullity, or might she give legal effect to the law in the teeth of her constitutional understanding? Our own intuition about this question, as wellsocialized participants in the U.S. legal system (which constitutes evidence about the understandings of other well-socialized participants, including officials), is that a constitutionally void law is no law at all.

Imagine that the Constitution explicitly stated the following at the beginning of Article I: "Any law inconsistent with any section of this Article is null and void." If judges followed a thick rule of recognition, then even such a crystal clear constitutional metaprovision would not settle the question whether, say, Article I, Section 8 states existence or application conditions. But we think it apparent, given the actual Constitution and constitutional culture, that most judges would regard the constitutional meta-provision as 
itself resolving the existence condition question, and if we are right in that assessment, this suggests quite strongly that the current rule of recognition in the actual U.S. legal system is thin, not thick.

Accordingly, if positivism provides an accurate account of the nature of law, we can determine whether a given constitutional provision goes to existence or application by using the ordinary sources of constitutional interpretation: text, history, structure, and moral considerations, as appropriately ordered by the correct interpretive theory. We look to the Constitution itself to answer the question of characterization.

But what if positivism is wrong? ${ }^{55}$ The most important competing theory within modern jurisprudence is Professor Ronald Dworkin's account. ${ }^{56}$ Professor Dworkin's account is more thoroughly moralized than the positivist's. Positivists (or at least some positivists) allow that moral considerations can determine legality insofar as these are incorporated by the rule of recognition, or by rules such as a constitution whose legality derives from the rule, but no positivist would allow that moral considerations can determine legality

\footnotetext{
${ }^{55}$ Jurisprudents may object that we have ignored the debate between hard and soft positivism. Very roughly, hard positivists believe that the law must be identifiable according to its source - in the case of a federal statute, for example, by whether it was enacted by Congress in conformity with Article I, $\$ 7$-and not by reference to moral considerations. See, e.g., Raz, supra note 17, at 47-48; Scott J. Shapiro, On Hart's Way Out, 4 Legal Theory 469,476 (1998). Soft positivists insist only on the conceptual possibility that law could be identified by its sources without regard to moral considerations, but allow that in some legal systems, the rule of recognition could make moral considerations relevant to identifying the law. See, e.g., Hart, supra note 13, at 250; Jules L. Coleman, Negative and Positive Positivism, 11 J. Legal Stud. 139 (1982). Our argument that a positivist would regard the question whether a given constitutional provision states an existence condition or an application condition as a constitutional question applies to both hard and soft positivists. Nothing in the claim that official practice recognizes the existence/application distinction as a constitutional (not extraconstitutional) issue entails the view that constitutional existence conditions incorporate moral considerations.

To be sure, some of what we claim may prove problematic for hard positivists. In particular, we argue in Part II that some constitutional rights provisions are best read, at least in some circumstances, as existence conditions. To the extent that those rights provisions-such as the guaranty of equal protection of the laws-and others are best read to incorporate moral considerations, the hard positivist cannot treat them as existence conditions, for that would violate the sources thesis. Yet we believe that the sorts of reasons that lead hard positivists to hard positivism would also lead them to conclude that provisions of the Constitution that incorporate moral considerations (if there are any) are not existence conditions.

${ }^{56}$ Ronald Dworkin, Law's Empire 254-58 (1986).
} 
in the teeth of the rule of recognition. Professor Dworkin thinks otherwise. He suggests (very roughly) that legality is a function of both "fit" with existing practices and moral values. Imagine a judge who (1) believes that prevailing practice is to look to various, recognized sources of constitutional interpretation in determining whether some constitutional provision wholly "voids" laws inconsistent with it, or merely trumps them, but (2) believes that it would be morally better to announce that the characterization of some provision as an existence condition or application condition is not itself an issue of constitutional law, and to resolve the characterization issue in a way that would not generally be seen as constitutional reasoning. Then this judge (in line with Dworkin's account) might depart from the recognized sources of constitutional interpretation in determining whether some provision is an existence or application condition. She would do so if she concluded that this decision would not create too much "misfit" with existing practice and that the moral value of doing so was sufficiently large.

We will not enter into the debate between positivists and Dworkinians here. Nor will we attempt a full analysis of the moral issue just identified that arises within Dworkin's account: whether a judicial decision to employ reasoning that would be seen as extraconstitutional in order to determine whether some constitutional provision voids or merely overrides inconsistent law could ever have sufficient moral value to warrant the evident misfit with practice, and thus render such a decision legally correct. We are quite skeptical, however, about the moral value of departing from constitutional practices in this way.

Our skepticism is grounded in the fact that moral considerations have a recognized role within our constitutional practices. For example, imagine a judge faced with the decision of whether the Commerce Clause states an existence condition or an application condition: specifically, whether a statute that has been enacted in accordance with Article I, Section 7, but applies to various activities that (as the judge reads the Commerce Clause) exceed federal power, should be wholly nullified or merely restricted in scope to activities that (as the judge sees it) are permissibly regulated at the federal level. Now imagine that the judge believes it would be morally best to wholly invalidate the statute. Then she can do so without flying in the face of the prevailing view that the role of the 
Commerce Clause is itself a constitutional issue. The judge might adduce the moral considerations she takes to be important as a factor bearing on constitutional interpretation and conclude that, as $a$ matter of constitutional interpretation, the Commerce Clause is an existence condition. Or, if she is reluctant to categorize the Commerce Clause in this way, given the implications for other cases, she might bracket the issue but determine that-in light of the moral considerations she sees as grounds for nullifying the statute-the severability clause of the statute should be read to preclude severance of the permissible from the impermissible applications. It is difficult to see why the judge would need to depart from prevailing characterization practices and characterize her decision to remedy the Commerce Clause violation by voiding the statute as "extraconstitutional."

What this example suggests is that misfit at the level of characterization practice $e^{37}$ would rarely be morally justified, since the Dworkinian judge could instead preserve fit at the level of characterization practice and (consistent with an approach to constitutional interpretation followed by many judges and citizens) describe the moral grounds for her decision as sources of constitutional law, for example, sources incorporated through open-ended constitutional texts such as the Equal Protection Clause or, alternatively, nontextual sources of constitutional law. Admittedly, this example is merely suggestive. Still, it seems plausible that for the Dworkinian, as for the positivist, the question whether a constitutional provision states an existence condition for nonconstitutional law or a mere constraint (application condition), should itself be considered a question of constitutional law. The methodology for the inquiry to which we now turn is constitutional rather than extraconstitutional.

${ }^{57} \mathrm{By}$ "characterization practice" here, we mean the practice of bringing to bear ordinary sources of constitutional interpretation in determining whether a constitutional provision states an application or existence provision-or, in other words, the practice of viewing the existence/application determination as a constitutional rather than extraconstitutional determination. 


\section{Parsing the Constitution for Existence Conditions And APPLICATION CONDITIONS}

This Part parses the Constitution into existence conditions and application conditions. In our view, one can make a plausible argument for the conclusion expressed by what was formerly the conventional wisdom: "An unconstitutional act is not a law ...." Our aim, however, is not to defend the proposition that every constitutional provision states an existence condition. Instead, we aim to dislodge the intuition that procedural mechanisms such as Article I, Section 7 are the only existence conditions, whereas substantive provisions such as the enumerated powers and individual rights clauses are application conditions. We argue in this Part that the category of existence conditions includes more than just proce-

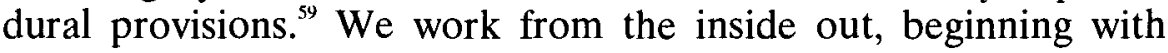
constitutional provisions that most clearly function as existence conditions and ending with less clear-cut examples. In turn, we address: (A) provisions that designate official actors such as Congress and the President; (B) provisions and doctrines-such as separation of powers-that define the mechanisms of lawmaking; (C) provisions and doctrines-such as federalism-that state subject matter limitations on lawmaking; and (D) provisions and doctrines that set forth individual rights.

\footnotetext{
${ }^{58}$ Norton v. Shelby County, 118 U.S. 425, 442 (1886).

${ }^{54}$ As we concluded in the previous Part, the question whether a particular constitutional provision states an existence condition or an application condition is itself a question of constitutional law. Accordingly, we analyze it using the conventional tools of constitutional interpretation, including doctrine. The consideration of doctrine might seem to render our argument circular. After all, the principal point of distinguishing existence conditions from application conditions is to justify judicial review for, at a minimum, the former. But if doctrine plays a role in this analysis, we might be said to have loaded the dice, for Marbury itself is a substantial precedent that is intertwined with the very cases upon which our argument relies. Thus, a charge of circularity might be raised. We would respond to this charge by noting that doctrine plays a relatively small role in our analysis. Moreover, even where we invoke cases, we tend to eschew doctrinal arguments qua doctrinal arguments. For example, in discussing both Bush v. Gore, 531 U.S. 98 (2000) and the enumerated powers cases, we point to the fact of consensus among Justices that various constitutional provisions are existence conditions, notwithstanding heated disagreement about the substantive content of these provisions. In these examples, we use their agreement epistemically: The fact that expert constitutionalists believe the provisions under discussion to be existence conditions counts as evidence that they are best understood that way.
} 


\section{A. Designating Official Actors}

Recall the core example elaborated so far. Plaintiff Smith appears before federal district judge Jones with a purported federal statute that grants Smith rights against defendant Acme. Before applying the statute, Jones must identify Congress and the President. Under rare circumstances, we can imagine disputes arising about the identity of each of these actors.

Begin with Congress. Was the Reconstruction Congress that enacted the Fourteenth Amendment and ordinary legislation during the exclusion of the southern congressional delegations actually Congress? Although the question has been settled as a matter of doctrine ${ }^{60}$ it was once a live issue. Indeed, even today, legal scholars unsympathetic to the secessionist cause treat the adoption of the Fourteenth Amendment as suspect under Article V because of the exclusion of southern Representatives. ${ }^{61}$ Unfortunately, it does not take any great leap of imagination to imagine that, following a catastrophic terrorist attack that crippled the government in Washington, there might be uncertainty as to which, if any, surviving legislators-totaling less than a quorum, perhaps-were authorized to act as Congress. As in the case of the Dorr Rebellion, ${ }^{62}$ after the crisis had passed, the courts might be called upon to adjudicate claims concerning the identity of the legislature. Yet in contrast to the circumstances surrounding the Dorr Rebellion-which involved the identity of a state legislature-with the identity of the national legislature uncertain, the courts obviously could not defer to the judgment of Congress. ${ }^{63}$

\footnotetext{
${ }^{60}$ Coleman v. Miller, 307 U.S. 433, 449-50 (1939) ("This decision by the political departments of the Government as to the validity of the adoption of the Fourteenth Amendment has been accepted."); United States v. Ass'n of Citizens Councils, 187 F. Supp. 846, 848 (W.D. La. 1960) ("With all deference to able counsel, we find ourselves unable to agree with th[e] contention [that the Fourteenth and Fifteenth Amendments were adopted unconstitutionally] in the light of the hundreds of cases in which the United States Supreme Court has applied these Amendments.").

${ }^{61}$ See 2 Bruce Ackerman, We the People: Transformations 99-119 (1998). Pursuant to his theory that amendment occurs during "constitutional moments" that need not comply with Article V, Ackerman concludes that the Reconstruction Amendments are indeed rightfully deemed part of the Constitution. Id. at 120-252.

${ }^{62}$ See Luther v. Borden, 48 U.S. (7 How.) 1 (1849).

${ }^{63} \mathrm{Cf}$. supra note 15 and accompanying text (discussing how the federal courts defer to Congress or state courts in determining the legitimate government of a state).
} 
Disputes as to the President's identity might also arise. One can readily imagine a somewhat different conclusion to the 2000 presidential election, in which both George Bush and Al Gore claim authority to act as President, Congress deadlocks, and the courts are called upon to decide who is the true President. ${ }^{64}$ In such circumstances, the political question doctrine would not be available. Again, in contrast to the Dorr Rebellion, in the imaginary "Gore Rebellion," there would be no federal authority to whom the courts might readily defer.

Are the constitutional provisions that establish Congress and the President best read as existence conditions or application conditions? It is difficult to understand how they could be read as anything other than existence conditions. ${ }^{65}$ The Constitution is a constitution precisely because it constitutes the federal government.

To be sure, one can envision circumstances in which the electoral provisions of the Constitution would not state existence conditions. Suppose, for example, that one political party were to become so dominant that real power was concentrated in that party's leadership. Suppose further that, over time, the entire apparatus of federal elections became a mere formality, so that the President and Congress took their marching orders from the party. Eventually, the seat of lawmaking power might shift to party standing committees and the like, even without a formal amendment of the Constitution. At that point, it seemingly would no longer be accurate to say that the Constitution set forth existence conditions for Congress and the President, but of course, under circumstances of one-party totalitarianism, the Constitution would cease to operate as law. In the existing U.S. legal culture, the mechanisms the Constitution establishes for selecting Congress and the President operate to identify the laws that those actors have a role in creating.

${ }^{64}$ See, e.g., Richard A. Posner, Florida 2000: A Legal and Statistical Analysis of the Election Deadlock and Ensuing Litigation, 2000 Sup. Ct. Rev. 1, $42-46$ \& 45 n.73 (considering recount scenario in which the Speaker of the House or President pro tempore of the Senate would serve as President "until the winner of the 2000 presidential election was somehow determined").

${ }^{65}$ These provisions are "indirect" existence conditions in the sense that they do not directly define some type of nonconstitutional law, but instead define the institutions that are referenced by constitutional provisions that do directly define some type of nonconstitutional law. Article I, § 7, for example, refers to the "House of Representatives," the "Senate," and the "President." 
Next suppose that the current Congress enacts the "Safeguarding Our Democracy Act" ("SODA"), which indefinitely extends the terms of Senators, Representatives, and the President. ${ }^{66}$ Pursuant to its powers under Article I, Section 4, Clause 1, and Article II, Section 1, Clause 4, Congress then repeals the statutory provision designating the first Tuesday in November as election day, substituting in its stead "such day as shall be set forth in further legislation declaring that the threat to American democracy from terrorists and rogue states has passed." Despite SODA, a majority of states attempt to hold federal elections on November 2, 2004, and the winners of these elections attempt to take their seats in Congress at noon on January 3,2005, as provided in Section 1 of the Twentieth Amendment. ${ }^{68}$ The holdover Congress refuses to seat them, citing SODA and the proposition that "the Constitution is not a suicide pact." ${ }^{169}$ The electoral victors assemble on the tennis courts adjacent to the Marriott Wardman Park Hotel in Washington, D.C. and begin enacting legislation, which is then submitted to the victorious candidate for President for signing on January 20, the day designated by the Twentieth Amendment as the end of the holdover President's term. ${ }^{70}$ Do these enactments have the status of law?

The political question doctrine provides little shelter for the holdover Congress and President. As in Powell v. McCormack, there is no claim that the new members of Congress lack the quali-

\footnotetext{
${ }^{66}$ While this hypothetical may seem far-fetched, recent events suggest otherwise. New York City Mayor Rudolph Giuliani's proposal to extend his own mayoral term by three months in the aftermath of the September 11th attacks gained considerable support, including the endorsement of both the Democratic and Republican nominees to succeed him. See Adam Nagourney, Battle in New York Mayor's Race: Cash vs. 'Instinct for the Jugular,' N.Y. Times, Oct. 14, 2001, at A1.

${ }^{67} 2$ U.S.C. $\$ 7$ (2000).

${ }^{68}$ U.S. Const. amend. XX, $\S 1$. ("[T]he terms of Senators and Representatives [shall end] at noon on the $3 \mathrm{~d}$ day of January ... and the terms of their successors shall then begin.").

Cf. Terminiello v. City of Chicago, 337 U.S. 1, 37 (1949) (Jackson, J., dissenting) ("There is danger that, if the Court does not temper its doctrinaire logic with a little practical wisdom, it will convert the constitutional Bill of Rights into a suicide pact.").

${ }^{70}$ U.S. Const. amend. XX, \& 1. ("The term[] of the President ... shall end at noon on the 20 th day of January ....").

" 395 U.S. 486, 516-49 (1969) (finding the question whether the House of Representatives could refuse to seat a member who, by the House's own admission, satisfied the constitutional criteria for membership, was justiciable).
} 
fications for office. Indeed, in Powell it was at least plausible to argue that the Constitution's silence permitted Congress to impose qualifications beyond those set forth in the document, whereas SODA directly conflicts with the Twentieth Amendment. Moreover, as we explain in greater detail in Part III, even if a court were to treat the question of which entity is Congress-the holdovers in the Capitol or the newcomers on the tennis court-as nonjusticiable, that decision itself, and the decision about whose judgment to accept as resolving the issue, would require the court to interpret the Constitution.

In any event, whatever temptation one may feel to treat the choice between two rival entities claiming to be Congress as a nonjusticiable political question results from an unnecessarily expansive reading of Luther $v$. Borden. ${ }^{72}$ That case surely should not be read as stripping the federal courts of all power to resolve contests between rival claimants to legislative authority. Rather, the Luther Court merely read the Guaranty Clause as establishing the federal government as the ultimate authority on what entity is a state government. ${ }^{73}$ True, under the Guaranty Clause it is "the United States" that guarantees the states a "Republican Form of Government," not Congress. ${ }^{74}$ Accordingly, the Supreme Court might have thought that it, as an arm of the United States, was responsible for identifying the legitimate government of Rhode Island. ${ }^{75}$ Yet it was also quite plausible to think that the act of guaranteeing a republican form of government would typically require force of arms, and therefore was best left in the hands of the political branches. The main point, though, is that there is no meta-Guaranty Clause in the Constitution, stating, for example, that the United Nations shall guarantee to the United States a republican form of government. Accordingly, notwithstanding Luther, in contests over the identity of the federal legislature or executive, federal courts will have to

\footnotetext{
${ }^{72} 48$ U.S. (7 How.) 1 (1849) (finding that federal courts lack the authority to adjudicate between two opposing factions, each of which claims to constitute the legitimate government of a state).

${ }^{73}$ Id. at 42.

${ }^{74}$ U.S. Const. art. IV, $\$ 4$.

${ }^{75}$ See Michael C. Dorf, The Relevance of Federal Norms for State Separation of Powers, 4 Roger Williams U. L. Rev. 51, 59-67 (1998) [hereinafter Dorf, Federal Norms] (exploring the limits of the principle that Guaranty Clause claims are not justiciable).
} 
make the choice themselves according to constitutional criteria. At the very least, the courts will have to explain-by reference to constitutional criteria-how and why they are deferring to some other federal actor (such as Congress in a dispute over the identity of the President or the President in a dispute over the identity of Congress).

The SODA example illustrates that the stakes in a contest over the identity of Congress or the President can be quite high, but the exact same problem is implicit in every invocation of a federal statute. It is, after all, always open to a defendant (or a plaintiff in the case of a putative statutory defense) to argue that the body that "enacted" the putative statute was a band of impostors. We doubt that there would be much uproar created by a decision by a federal judge that a "statute" enacted by the inmates of a maximum security prison created no legal rights or duties, despite the inmates' claim to be Congress, because, in the judge's best reading of the Constitution, the inmates in fact are not Congress.

If the Constitution states the existence conditions for Congress and the President, it plays a smaller but still important role in setting forth existence conditions for state lawmakers. For one thing, Article IV, Section 3, Clause 1 plays a leading role in identifying what entities are states. ${ }^{76}$ Accordingly, if Congress were to admit the island of Manhattan to statehood over the objection of the New York state legislature, in clear violation of Article IV, Section 3, Clause 1 , that act of admission would be ineffective and, for example, federal courts sitting in diversity suits would not recognize Manhattan's utterances as state law-unless, pursuant to the sorts of arguments considered in Part III, the courts were to conclude that the issue presented a nonjusticiable political question. ${ }^{77}$

\footnotetext{
76 New States may be admitted by the Congress into this Union; but no new State shall be formed or erected within the Jurisdiction of any other State; nor any State be formed by the Junction of two or more States, or Parts of States, without the Consent of the Legislatures of the States concerned as well as of the Congress.

U.S. Const. art. IV, $\S 3$, cl. 1 .

${ }^{77}$ See Adam H. Kurland, Partisan Rhetoric, Constitutional Reality, and Political Responsibility: The Troubling Constitutional Consequences of Achieving D.C. Statehood by Simple Legislation, 60 Geo. Wash. L. Rev. 475, 502 (1992) (suggesting the possibility "that Congress' decision to admit new states is a nonjusticiable political question").
} 
Article IV's Guaranty Clause also entails existence conditions for state institutions and actors. ${ }^{78}$ If former Governor Jesse Ventura attempted to exercise absolute power as King of Minnesota, that attempt surely would violate the Guaranty Clause, and Congress could plainly authorize and effectuate his removal even if the federal courts, absent congressional intervention, would be obliged to recognize Ventura's decrees as Minnesota law. ${ }^{79}$ Moreover, the broadest legal realist reading of Erie Railroad Co. v. Tompkins ${ }^{80}$ in which state law is whatever a state high court says it is ${ }^{81}$-must be rejected as inconsistent with the existence condition for state institutions set forth in the Guaranty Clause. The Minnesota Supreme Court could not, consistent with the Guaranty Clause, declare itself the absolute ruler of Minnesota any more than could former Governor Ventura.

Just how far toward absolute authority state high courts can stray (consistent with the Constitution) is unclear. Writing for himself, Justice Scalia, and Justice Thomas in his concurrence in Bush v. Gore, Chief Justice Rehnquist asserted that, where the federal Constitution assigns a federal function to a state "legislature," the state high court's construction of that body's enactments is subject to "independent, if still deferential" review by the U.S. Supreme

${ }^{78}$ "The United States shall guarantee to every State in this Union a Republican Form of Government, and shall protect each of them against Invasion; and on Application of the Legislature, or of the Executive (when the Legislature cannot be convened) against domestic Violence." U.S. Const. art. IV, § 4.

${ }^{79}$ As we noted in Part I and further explain in Part III, a constitutional provision can operate as an existence condition for some actor or branch but not for others. The Guaranty Clause may be such a provision. But see New York v. United States, 505 U.S. 144, 184-85 (1992) (noting that "the Court has suggested that perhaps not all claims under the Guaranty Clause present nonjusticiable political questions" (citing Reynolds v. Sims, 377 U.S. 533, 582 (1964))); Dorf, Federal Norms, supra note 75, at 59 n.38 (citing academic literature suggesting Guaranty Clause justiciability).

${ }^{80} 304$ U.S. 64 (1938).

${ }^{81}$ See Michael C. Dorf, Prediction and the Rule of Law, 42 UCLA L. Rev. 651, 707 (1995) [hereinafter Dorf, Prediction] (describing Justice Frankfurter's opinion for the Court in Guaranty Trust Co. v. York, 326 U.S. 99 (1945), as endorsing "the radical realist view that state law is, by definition, precisely what the state judges say it is"). The classic statement of this legal realist credo was proffered by Justice Holmes. See Oliver Wendell Holmes, The Path of the Law, Address at the Dedication of the New Hall of Boston University School of Law (Jan. 8, 1897), in Collected Legal Papers 167,173 (1952) (describing law more generally as "[t]he prophecies of what the courts will do in fact"). 
Court. ${ }^{82}$ Although the Bush v. Gore dissenters thought the Chief Justice accorded the Florida Supreme Court far too little deference ${ }^{83}$ they did not appear to disagree with the basic proposition that a state high court that willfully disregarded the legislature's enactments with respect to a federal election would violate the Constitution. $^{84}$

More pertinent to our purposes here, despite heated disagreement on virtually every other aspect of the case, all of the Justices in Bush v. Gore appeared to accept the proposition that, in some circumstances, the federal courts have ultimate authority to determine whether a given proposition actually constitutes an utterance of the state legislature. That agreement is consistent with the view expressed in McPherson v. Blacker that a state "legislature," as that term is used in the federal Constitution, is a particular institution. $^{85}$ Significantly, McPherson was one of only two precedents cited by the Court in its first-and unanimous-foray into the aftermath of the 2000 presidential election. ${ }^{86}$ Presumably, had the Florida Supreme Court explicitly stated that it ruled as it did because it thought that it and it alone was the Florida legislature, all nine Justices would have found a constitutional problem (although the dissenters might still have thought that any remedy lay with Congress). Under current doctrine, therefore, it is plain that while state constitutions typically set forth most of the existence conditions for state entities, the federal Constitution contains some existence conditions that place bounds around those entities, at least when they are performing federal functions. ${ }^{87}$

Finally, note that the Constitution appears to set forth existence conditions for federal judges themselves. We can certainly envision

\footnotetext{
${ }^{82} 531$ U.S. 98, 114 (2000) (Rehnquist, C.J., concurring).

${ }^{83}$ See id. at 135-43 (Ginsburg, Stevens, Souter, \& Breyer, JJ., dissenting).

${ }^{84}$ See id. at 139-40 (Ginsburg, Stevens, Souter, \& Breyer, JJ., dissenting) (giving examples of such rare willfulness).

${ }^{85} 146$ U.S. 1, 25-26 (1892).

${ }^{86}$ See Bush v. Palm Beach County Canvassing Bd., 531 U.S. 70,76 (2000).

${ }^{87}$ With respect to state functions, the Guaranty Clause expresses most of the relevant constitutional limits. We say most rather than all because some of the prohibitory language of Article I, $\S 10$, Clause 1 , as well as the Fourteenth Amendment's Due Process Clause, places limits on how state offices are structured. For example, were a state official designated the "Duke of New York" and assigned the power to levy taxes, the prohibition on titles of nobility would probably best be read to render the Duke's decrees without force.
} 
issues arising over whether a judge was properly appointed in the first instance. Suppose that John Marshall had neglected to deliver a commission to an Article III judge rather than a justice of the peace. Marbury makes quite clear that had there been original jurisdiction in the Supreme Court, the Court would have considered the underlying validity of the appointment. Indeed, the Court did consider the validity of the appointment. ${ }^{88}$ Together with the timetested proposition that courts always have jurisdiction to determine their own jurisdiction, ${ }^{89}$ Marbury's expansive dicta support the conclusion that, in a lawsuit adjudicated by Judge Jones, she would be obliged to consider her own identity as a federal judge if the issue were raised (by a litigant or, indeed, by the judge herself). Likewise, in rare circumstances, a federal judge might be called upon to decide whether she had been properly impeached."

A state judge would also have to decide whether she is in fact a state judge, but the relevant sources would be found primarily in state law. Federal constitutional law would not be entirely irrelevant in such circumstances, however. For example, both due process and the Article I, Section 10 bar on state bills of attainder forbid adjudication by a state "court" consisting of the state legislature. Such limits, relating as they do to who counts as a state authority, are best read as existence conditions for the utterances of putative state authorities.

In sum, the constitutional provisions governing the selection of Congress, the President, and federal judges, as well as scattered

\footnotetext{
${ }^{88}$ Marbury, 5 U.S. (1 Cranch) at 162 ("Mr. Marbury, then, since his commission was signed by the president, and sealed by the secretary of state, was appointed; and as the law creating the office, gave the officer a right to hold for five years independent of the executive, the appointment was not revocable...."). We pass over the question of what procedures the Constitution requires for the appointment of lower court judges. Article II sets forth the appointments process for "Judges of the supreme Court," as well as "all other Officers of the United States." U.S. Const. art. II, $\$ 2$, cl. 2. Whether lower court judges are the sort of inferior "Officers" whose appointment need not go through Senate confirmation is a question we do not address.

${ }^{89}$ See, e.g., United States v. Ruiz, 122 S. Ct. 2450, 2454 (2002) (citing United States v. United Mine Workers, 330 U.S. 258, 291 (1947)) ("[I]t is familiar law that a federal court always has jurisdiction to determine its own jurisdiction.").

${ }^{90}$ See Nixon v. United States, 506 U.S. 224, 253-54 (1993) (Souter, J., concurring) (reasoning that if the Senate used a sufficiently arbitrary procedure, such as tossing a coin, it might forfeit the protection granted to it to decide what counts as an impeachment trial).
} 
provisions limiting or assigning tasks to state institutions, set forth existence conditions. Putative propositions of law that purport to be actual propositions of law by virtue of having emanated from these actors cannot be employed as such without a preliminary determination that the actors in question are-so far as the Constitution is concerned-who they claim to be.

\section{B. Mechanisms of Lawmaking}

The core example of the putative statute demonstrates that Article I, Section 7 sets forth existence conditions for legislation. If the piece of paper that Smith calls a statute is actually a bill that passed the House but not the Senate, or a bill that the President vetoed, or just a piece of paper on which Smith typed words seeming to grant him rights, then Judge Jones "enforces" Article I, Section 7 by refusing to treat Smith's piece of paper as a statute.

Consider a more detailed version of the core example set forth in the Introduction: The "Fiscal Responsibility Act" ("FRA") is a (hypothetical) statute requiring a three-fifths majority in each house for all subsequent measures raising taxes and declaring itself amendable only by a three-fifths majority in each house. Let us put aside the possibility that FRA operates as a procedural rule and assume rather that it is (perhaps foolishly in light of the possibility of procedural circumvention of Article I, Section $7^{91}$ ) in fact a statute

${ }^{91}$ The House of Representatives has adopted an internal rule with the effect of FRA, except that the rule does not purport to entrench itself. See H.R. Doc. No. 107284, at 853 (2003) (setting forth House Rule XXI(5)(b)), available at http://www.house.gov/rules/RXXI.htm ("A bill or joint resolution, amendment, or conference report carrying a Federal income tax rate increase may not be considered as passed or agreed to unless so determined by a vote of not less than three-fifths of the Members voting, a quorum being present."). The Senate does not have such a requirement, but the cloture rule-under which a three-fifths vote is necessary to break a filibuster, S. Doc. No. 107-1, at 20-21 (2002) (setting forth Senate Rule XXII(2)), available at http://rules.senate.gov/senaterules/rule22.htm-operates as a de facto equivalent. Whether the predecessor to House Rule XXI(5)(b) is constitutional has been the subject of lively debate focusing on the scope of Congress's power to accomplish indirectly by rule what it cannot accomplish directly by statute. Compare Bruce Ackerman et al., An Open Letter to Congressman Gingrich, 104 Yale L.J. 1539 (1995) (arguing that the House supermajority requirement for tax measures contravenes Article I, § 7), with John O. McGinnis \& Michael B. Rappaport, The Constitutionality of Legislative Supermajority Requirements: A Defense, 105 Yale L.J. 483 (1995) (arguing that it does not). We bracket that debate by assuming an actual statute that sets forth the supermajority requirement and that purports to entrench itself. 
purporting to set limits upon subsequent legislation. After the enactment of FRA, is a measure raising revenue that passes both houses of Congress by simple majorities and receives the President's signature a statute?

A court asked to apply FRA (in, say, a tax evasion prosecution of Jane Doe), must now identify which of Congress's utterancesFRA or the measure purporting to repeal FRA-is authoritative. The longstanding rule is that in cases of irreconcilable conflict, the more recent utterance prevails. ${ }^{92}$ This unenumerated but (until recently) uncontroversial ${ }^{93}$ constitutional rule is itself an existence condition for legislation: To qualify as a source of law, a putative statute that is an otherwise authoritative utterance under Article I, Section 7, and any other existence conditions the Constitution may contain, must also not conflict with a subsequent statute. In our example, at least the portion of FRA that purports to require a supermajority for its own amendment does not satisfy the existence condition requiring that statutes not have been repealed. And the entrenchment provision is the very heart of FRA, for without it, a subsequent Congress could raise revenue through a simple majority vote that simultaneously repealed FRA and raised revenue.

Accordingly, it appears that the basic problem with FRA is that it contravenes the (unenumerated) constitutional existence condition stating that last-in-time legislative utterances prevail. Article I, Section 7 does little work in this example. After all, even constitutional systems with minimal judicial review-such as the English constitution in the classic Diceyan conception-recognize that repealed statutes lack binding force: The one unchangeable constitutional rule in the Westminster model is that the Queen in Parlia-

\footnotetext{
${ }^{92}$ See, e.g., Conn. Nat'l Bank v. Germain, 503 U.S. 249, 253 (1992) ("[S]o long as there is no 'positive repugnancy' between two laws, a court must give effect to both." (quoting Wood v. United States, 41 U.S. (16 Pet.) 342, 363 (1842))); Georgia v. Pa. R.R. Co., 324 U.S. 439, 457 (1945) ("[A] clear repugnancy between the old law and the new results in the former giving way...."); Town of Red Rock v. Henry, 106 U.S. 596, 601-02 (1883) ("[W]hen an affirmative statute contains no expression of a purpose to repeal a prior law, it does not repeal it unless the two acts are in irreconcilable conflict, or unless the later statute covers the whole ground occupied by the earlier and is clearly intended as a substitute for it, and the intention of the legislature to repeal must be clear and manifest.").

${ }^{93}$ See Eric A. Posner \& Adrian Vermeule, Legislative Entrenchment: A Reappraisal, 111 Yale L.J. 1665 (2002).
} 
ment can make or unmake any law. ${ }^{94}$ Constitutionally speaking, the Queen in Parliament cannot make a rock so heavy that she herself cannot lift it-and neither can Congress. ${ }^{95}$

But the fact that the American and English constitutional systems share the principle that last-in-time legislation prevails does not render Article I, Section 7 unimportant. Whether some utterance really is a "statute" that repeals prior statutes depends on whether it satisfies the bicameralism and presentment requirements of Article I, Section 7.

If the last-in-time principle means that courts must disregard laws purporting to make the enactment of legislation more difficult than under the Article I, Section 7 procedure, a different sort of argument is needed to show that they must disregard laws purporting to make the enactment of legislation easier. A congressional grant of permission to some person or body-such as the President, one house of Congress, the Comptroller General, nine members of Congress, or a private industry group-to enact laws would not violate the last-in-time principle so long as Congress retained the power, acting pursuant to the procedures of Article I, Section 7, to revoke the delegation. Of course, as the examples just invoked suggest, such a grant may be held unconstitutional on other grounds. ${ }^{96}$

\footnotetext{
${ }^{94}$ See Albert Venn Dicey, Introduction to the Study of the Law of the Constitution 39-40 (1965) ("[T]he Queen, the House of Lords, and the House of Commons . . . acting together [can] be ... described as the 'Queen in Parliament,' and constitute Parliament... Parliament thus defined has ... the right to make or unmake any law whatever; and, further, that no person or body is recognised by the law of England as having a right to override or set aside the legislation of Parliament."); O. Hood Phillips et al., Constitutional and Administrative Law 110-11, 476-78 (8th ed. 2001) (discussing restrictions on Westminster parliamentary sovereignty posed by international human rights documents).

${ }_{95}$ See 1 Laurence H. Tribe, American Constitutional Law § 2-3, at $125 \mathrm{n} .1$ (3d ed. 2000) ("[T]he power of Congress legislatively to bind subsequent Congresses is limited, for any statute that purported to direct or to forbid subsequent Congresses to do certain things or to follow certain procedures could be repealed, as could any other law, by another duly enacted statute.").

${ }^{96}$ See Clinton v. City of New York, 524 U.S. 417 (1998); Metro. Wash. Airports Auth. v. Citizens for the Abatement of Aircraft Noise, Inc., 501 U.S. 252 (1991); Bowsher v. Synar, 478 U.S. 714 (1986); INS v. Chadha, 462 U.S. 919 (1983); A.L.A. Schechter Poultry Corp. v. United States, 295 U.S. 495 (1935); Pan. Ref. Co. v. Ryan, 293 U.S. 388 (1935).
} 
Likewise, judicial decisions construing the Appointments Clause, ${ }^{47}$ the Take Care Clause, ${ }^{98}$ and the general doctrine of separation of powers limit the mechanisms by which various persons or bodies are selected and/or terminated. ${ }^{99}$ Such decisions read the Constitution as setting forth existence conditions for agencies and officials, and thus they also read the Constitution as setting forth existence conditions for the sub-statutory law produced by these agencies and officials: Sub-statutory law emanating from agencies and officials whose exercise of official power violates the Constitution is invalid.

We do not take a position on the correctness of any particular judicial decision limiting who may exercise what form of congressionally delegated power. Our point is a simple one: In our legal culture, Article I, Section 7 and other separation-of-powers provisions function as limits on the mechanisms by which Congress and other entities to whom Congress delegates power may make law. If Congress or some other actor attempts to make law in violation of the limits set forth in Article I, Section 7, the Appointments Clause, the Take Care Clause, the last-in-time principle, or the general principle of separation of powers-whatever exactly those limits might be-that actor's pronouncements are ineffective.

If the piece of paper that plaintiff Smith waves before Judge Jones is not a putative statute but an agency regulation that, according to defendant Acme, is outside the agency's authority because the statute authorizing its promulgation provided the agency with no "intelligible principle," Judge Jones treats the non-

${ }^{97}$ U.S. Const. art. II, $\S 2$, cl. 2.

${ }^{98}$ Id. art. II, $\$ 3$.

${ }^{99}$ See Edmond v. United States, 520 U.S. 651 (1997); Mistretta v. United States, 488 U.S. 361 (1989); Morrison v. Olson, 487 U.S. 654 (1988); Bowsher, 478 U.S. 714; Buckley v. Valeo, 424 U.S. 1 (1976); Humphrey's Ex'r v. United States, 295 U.S. 602 (1935); Myers v. United States, 272 U.S. 52 (1926). On the theme of constitutional existence conditions for substatutory federal law, see also Larry Alexander \& Evan Tsen Lee, Is There Such a Thing As Extraconstitutionality? The Puzzling Case of Dalton v. Specter, 27 Ariz. St. L.J. 845 (1995) (arguing that executive action exceeding statutory authority is unconstitutional absent direct constitutional empowerment of executive action).

${ }^{100}$ See Whitman v. Am. Trucking Ass'ns, 531 U.S. 457, 472 (2001) (requiring that Congress "lay down by legislative act an intelligible principle to which the person or body authorized to [act] is directed to conform," (quoting J.W. Hampton, Jr., \& Co. v. United States, 276 U.S. 394, 409 (1928))). 
delegation doctrine as an existence condition for the regulation. Likewise, when New York City claimed a right to funds that Congress appropriated but that the President witheld pursuant to his putative line-item-veto power, the Court treated (the judicial gloss on) Article I, Section 7 as stating an existence condition (though it did not use the term "existence condition"). ${ }^{101}$ And if Congress and the President enter into agreements with foreign sovereigns through a mechanism other than the treaty power, the courts, if faced with a challenge to putative laws enforcing those agreements, would need to decide whether, as Professor Laurence Tribe argues, the treaty-making provision of Article II, Section 2 sets forth the exclusive mechanism by which such international agreements can be made ${ }^{102}$ (that is, whether, in addition to satisfying the conditions of Article I, Section 7, a piece of legislation must also, in some sense, concern domestic affairs in order to exist as a valid law).

To be clear, we are not here interested in whether Article II, Section 2 is best read as exclusive of agreements with foreign sovereigns accomplished via the Article I, Section 7 route. We invoke this example because it serves as a bridge to the next Section, in which we ask whether the enumerated powers in Article I, Section 8 and elsewhere function as existence conditions. Note that if Professor Tribe is correct and Article II, Section 2 is exclusive, then it is not so easy to treat constitutional provisions and doctrines that set forth the mechanisms of lawmaking-such as Article I, Section 7-as stating existence conditions while distinguishing subjectmatter limits-such as the enumerated powers provisions we discuss shortly-as stating application conditions. For under Professor Tribe's reading of Article II, Section 2, in order to determine whether a putative provision of law has gone through the proper procedure for enactment, one must first determine, based on the putative provision's subject matter, what procedure is appropriate (and then ask whether that procedure has been followed). Indeed,

\footnotetext{
${ }^{101}$ See Clinton, 524 U.S. at 417.

${ }^{102}$ Compare Laurence H. Tribe, Taking Text and Structure Seriously: Reflections on Free-Form Method in Constitutional Interpretation, 108 Harv. L. Rev. 1221 (1995) (arguing that Article II, $\S 2$ is exclusive), with Bruce Ackerman \& David Golove, Is NAFTA Constitutiona1?, 108 Harv. L. Rev. 799 (1995) (arguing that the treaty power does not exclude congressional-executive agreements as a mechanism for joint undertakings with foreign sovereigns).
} 
even if Professor Tribe is incorrect, it would still be necessary to employ that two-step process for sorting between the Article I, Section 7 route and the Article II, Section 2 route if one were to accept the complementary proposition that the treaty power may only be used, as Chief Justice Charles Evans Hughes put it, "for the purpose of having treaties made relating to foreign affairs and not to make laws for the people of the United States in their internal concerns through the exercise of the asserted treaty-making power." 103 And if, on either the Tribe hypothesis or the Hughes hypothesis, the two-step process is appropriate for sorting between the Article I, Section 7 route and the Article II, Section 2 route at the border between legislation and treaty-making, then it would seem equally appropriate for sorting between those provisions of law that come into existence via congressional enactment and those that must come into existence, if at all, through state lawmaking mechanisms.

\section{Subject-Matter Limits}

James Madison and others of the Founding generation expected the enumeration of powers to be the principal mechanism by which the Constitution would limit the scope of federal authority. ${ }^{104}$ That expectation was frustrated, if not as early as McCulloch v. Maryland ${ }^{105}$ then certainly by the middle of the twentieth century. ${ }^{106}$ Even today, despite a much-heralded revival of federalism, as far as subject-matter competence goes, the federal government is almost omnipotent. Significantly, of the recent spate of federalism decisions, only three-United States v. Lopez, City of Boerne $v$. Flores, ${ }^{107}$ and United States $v$. Morrison ${ }^{108}$-find the regulation of

${ }^{103}$ Proceedings of the American Society of International Law at Its Twenty-Third Annual Meeting Held at Washington, D.C.-April 24-27, 1929, 23 Proc. Am. Soc'y Int'l L. 196 (1929) (remarks of Charles Evans Hughes). Whether the treaty power contains such a limit is unclear. See Thomas Healy, Note, Is Missouri v. Holland Still Good Law? Federalism and the Treaty Power, 98 Colum. L. Rev. 1726, 1732 (1998).

${ }^{104} 1$ Annals of Cong. 437-38 (Joseph Gales ed., 1789), reprinted in A Second Federalist 268-70 (Charles S. Hyneman \& George W. Carey eds., 1967); The Federalist No. 45, at 260-61 (James Madison) (Clinton Rossiter ed., 1999).

${ }^{105} 17$ U.S. (4 Wheat.) 316 (1819).

${ }^{106}$ See Wickard v. Filburn, 317 U.S. 111 (1942).

${ }^{107} 521$ U.S. 507 (1997).

${ }^{108} 529$ U.S. 598 (2000). 
particular categories of acts wholly beyond the power of the federal government (and even then Congress may be able to achieve the objectives of the invalidated legislation through conditional exercises of the spending power ${ }^{109}$ ). Other recent decisions invalidating national legislation on federalism grounds limit the circumstances in which states can be sued ${ }^{110}$ or enforce "etiquette" rules about how Congress may legislate on matters within its subjectmatter competence. ${ }^{111}$

Nonetheless, the federal government is not omnipotent. Even the Justices who continue to adhere to the spirit and not just the letter of Garcia v. San Antonio Metropolitan Transit Authority ${ }^{112}$ do not take the view that there are no limits to the subjects on which Congress may legislate-even if they would grant Congress substantial deference in the interpretation of those limits (a point to which we return in Part III). And a majority of the Court would clearly go further in setting limits. Lopez, Boerne, and Morrison appear to place some activities wholly outside of congressional control, and the sovereign immunity and "etiquette" decisions may have that effect with respect to some activities undertaken by the states.

Accepting that the enumerated powers limit the scope of federal authority, do they state existence conditions or application conditions? We think that if constitutional doctrine had evolved differently, a plausible case could have been made for treating such provisions as application conditions, yet the actual doctrine treats enumerated powers as existence conditions. Further, although we do not argue the point in any detail, we think that existing doctrine is sensible in this respect.

${ }^{109}$ See, e.g., South Dakota v. Dole, 483 U.S. 203, 207 (1987) ("[O]bjectives not thought to be within Article I's 'enumerated legislative fields,' may nevertheless be attained through the use of the spending power and the conditional grant of federal funds." (quoting United States v. Butler, 297 U.S. 1, 65 (1936))).

${ }^{110}$ Fed. Mar. Comm'n v. S.C. State Ports Auth., 535 U.S. 743 (2002); Bd. of Trs. v. Garrett, 531 U.S. 356 (2001); Kimel v. Fla. Bd. of Regents, 528 U.S. 62 (2000); Fla. Prepaid Postsecondary Educ. Expense Bd. v. Coll. Sav. Bank, 527 U.S. 627 (1999).

${ }^{111}$ Printz v. United States, 521 U.S. 898 (1997); New York v. United States, 505 U.S. 144 (1992); Matthew D. Adler \& Seth F. Kreimer, The New Etiquette of Federalism: New York, Printz, and Yeskey, 1998 Sup. Ct. Rev. 71.

${ }^{112} 469$ U.S. 528 (1985). 
How would constitutional doctrine look if the enumerated powers provisions functioned as application conditions? One can imagine that when Article I, Section 8 confers on Congress the "Power to ... regulate Commerce ... among the several States," it confers a power to regulate specific acts of interstate commerce. On this reading, the Commerce Clause would not state an existence condition for legislation. A putative statute would be valid so long as it satisfied the Article I, Section 7 requirements; but such valid legislation could not be applied to acts that did not themselves comprise interstate commerce.

For example, a law banning the possession of firearms near schoolyards could not be constitutionally applied to a person merely possessing a homemade gun near a schoolyard, but it could be applied consistent with the Commerce Clause (in this alternative universe) if the person charged with violating it were apprehended in the course of an interstate journey that brought him to a schoolyard where he sold a firearm. Likewise, a law limiting agricultural production could not be constitutionally applied to a subsistence farmer, but could be applied to a factory farm that sold its products on the interstate market. If Commerce Clause doctrine and doctrines involving other enumerated powers functioned in this way, the statutory provisions at work in a particular case would be irrelevant to the question of constitutional power. The only constitutional question would be whether the will of Congress was, in the particular case, being brought to bear on an object within the scope of the enumerated power to regulate interstate commerce. Such an application condition could be nonenforced coherently without creating any difficulties for a court's role in applying ordinary nonconstitutional law.

In fact, however, Commerce Clause doctrine does not turn on particular acts regulated in particular cases. Whether Congress has acted within the scope of the Commerce Clause depends upon whether the law Congress enacted regulates either the channels or instrumentalities of interstate commerce or classes of economic activities that, taken in the aggregate, substantially affect interstate commerce. ${ }^{113}$ This approach makes good sense. At least since Gib-

\footnotetext{
${ }^{113}$ See Morrison, 529 U.S. at 607-19; Lopez, 514 U.S. at 549, 558-68.
} 
bons $v$. Ogden,${ }^{114}$ constitutional law has sensibly recognized that the characterization of any particular action as an instance of "interstate commerce" is quite arbitrary. ${ }^{115}$ Even if one were inclined to roll back the scope of the Commerce Clause to cover, say, shipment but not manufacturing, it would still be much easier for courts to police the bounds of congressional power by looking to the predicate of regulation rather than attempting to characterize each particular act subject to regulation. ${ }^{116}$

To be sure, Congress sometimes chooses to include in its statutes a "jurisdictional nexus"- that is, a requirement that the government prove that the acts to which a statute is applied in a given case themselves affect interstate commerce. ${ }^{117}$ The Court has also expressed a willingness to uphold statutes containing such a nexus where, absent the nexus, the statute's relation to interstate commerce would be doubtful. ${ }^{118}$ Yet even in such cases, the constitutional (existence) question is whether the statute contains a jurisdictional nexus, Whether the nexus is satisfied in particular circumstances is a distinct question about the statute's scope to be decided only once the statute's existence has been established.

Of course, the decision by the Court to treat the presence or absence of a jurisdictional nexus as relevant to a statute's validity (that is, existence) under the Commerce Clause may be a mistake. Perhaps it would be better to ask, as the Lopez and Morrison dissenters apparently would, simply whether the category of regulated activity, be it economic or noneconomic in character, has, in the

\footnotetext{
${ }^{114} 22$ U.S. (9 Wheat.) 1 (1824).

${ }^{115}$ In Gibbons, the Court recognized congressional power "to prescribe the rule by which commerce is to be governed," id. at 196 , rather than the power to govern discrete acts.

${ }^{116}$ Thus, it is not surprising to see that in the heyday of the distinction between manufacturing and trade, the Supreme Court understood its task as judging the validity of statutes. See Hammer v. Dagenhart, 247 U.S. 251, 277 (1918) (concluding that the challenged "law exceed[ed] the constitutional authority of Congress").

${ }^{117}$ For instance, it is unlawful for a felon to "possess in or affecting commerce, any firearm or ammunition." 18 U.S.C. $\$ 922(\mathrm{~g})$ (2000) (emphasis added). Likewise, the Child Support Recovery Act contains an express jurisdictional element. See 18 U.S.C. $\S 228$ (2000) ("[Whoever] willfully fails to pay a past due support obligation with respect to a child who resides in another State [shall be liable] ...." (emphasis added)).

${ }^{118}$ See Lopez, 514 U.S. at 561-63; see also United States v. McAllister, 77 F.3d 387, 390 (11th Cir. 1996) (upholding 18 U.S.C. $\$ 922(\mathrm{~g})(1)$ because of jurisdictional nexus); United States v. McHugh, 967 F. Supp. 1279, 1281-82 (N.D. Ga. 1997) (upholding 18 U.S.C. $\$ 228$ because of jurisdictional nexus).
} 
aggregate, a substantial effect on interstate commerce. ${ }^{119}$ Or perhaps, as suggested in Part $I$, the proper test for validity under the Commerce Clause should be whether the congressional enactment addresses a matter on which the states are unable to act individually, because of collective action problems, interstate externalities, or similar phenomena. ${ }^{120}$ Whichever of these tests is best, however, each assumes that the Commerce Clause states a condition for the validity of legislation, rather than stating a test for the validity of the application of Congress's will to particular sets of circumstances. In other words, whatever disagreement there is about the proper scope of the Commerce Clause, there is no live debate about whether it states an existence condition or an application condition. All agree (tacitly) that it states an existence condition.

Likewise, in applying the "congruence and proportionality" test under Section 5 of the Fourteenth Amendment, the Court has not asked whether the remedies provided in various acts of Congress are congruent and proportional to a constitutional violation presented by the particular facts of the cases before the Court. Suppose, for example, that the plaintiff in Kimel v. Florida Board of Regents $^{121}$ or Board of Trustees $v$. Garrett ${ }^{122}$ had been the victim of intentional, irrational discrimination by the State-the sort of discrimination that the Supreme Court itself would recognize as unconstitutional and for which the Court would therefore permit Congress to provide a damages remedy against the State. It seems obvious that the Court would nonetheless have ruled against the plaintiff because the statute Congress in fact enacted-the Age Discrimination in Employment Act or the Americans with Disabilities Act-applied to a much wider category of State activity without sufficient justification. Strikingly, in the actual Kimel and Garrett cases, neither the majority nor the dissent analyzed the

${ }^{119}$ Morrison, 529 U.S. at 656-61 (Breyer, Stevens, Souter, \& Ginsburg, JJ., dissenting); Lopez, 514 U.S. at 615-17 (Breyer, Stevens, Souter, \& Ginsburg, JJ,, dissenting).

${ }^{120}$ See, e.g., Donald H. Regan, How To Think About the Federal Commerce Power and Incidentally Rewrite United States v. Lopez, 94 Mich. L. Rev. 554, 555 (1995) (suggesting that "when we are trying to decide whether some federal law or program can be justified under the commerce power, we should ask ourselves the question, 'Is there some reason the federal government must be able to do this, some reason why we cannot leave the matter to the states?"').

${ }^{121} 528$ U.S. $62(2000)$.

${ }^{122} 531$ U.S. 356 (2001). 
question whether the particular plaintiffs themselves were the victims of unconstitutional discrimination, but focused instead on whether the statute Congress put through the Article I, Section 7 process satisfied (what the majority and dissent respectively regarded as) the constitutional test for validity (under Section 5 of the Fourteenth Amendment in the view of the majority, and under either that section or the Commerce Clause in the view of the dissent). The Justices all regarded the enumerated powers as setting forth existence conditions for legislation. ${ }^{123}$

An important caveat exists, however, concerning the courts' power to sever unconstitutional provisions and applications of statutes from their constitutional provisions and applications. ${ }^{124} \mathrm{Ex}-$ istence conditions that turn on the source from which or the procedure by which a piece of text becomes law are immune to severability analysis. If the "Safe Workplaces Act" passed the House but not the Senate, or was signed by the Secretary of Labor but not the President, it is not a law, and neither is any part of it. ${ }^{125}$ Courts face a different situation when confronted with existence conditions that depend on content. The Court in Morrison apparently took for granted that it could invalidate the civil remedy provision of the Violence Against Women Act without calling into question the (many) other provisions of the Act that were passed along with it. ${ }^{126}$

${ }^{123}$ On rare occasions, the Court has purported to measure the validity of a statute challenged under what we would deem an existence condition "as applied." See Salinas v. United States, 522 U.S. 52, 60 (1997) ("[T]here is no serious doubt about the constitutionality of [the federal bribery statute] as applied to the facts of this case."); United States v. Raines, 362 U.S. 17, 24-25 (1960) (apparently validating federal civil rights action on the ground that the particular conduct alleged was regulable by Congress under the Fifteenth Amendment). In our view, this anomalous approach at most suggests that, in addition to stating existence conditions for legislation, the enumerated powers may also sometimes operate as application conditions for valid statutes. See infra text accompanying notes 137-38 (explaining that a single constitutional provision can function as both an existence condition and an application condition).

${ }^{124}$ See, e.g., INS v. Chadha, 462 U.S. 919, 934-35 (1983).

${ }^{125}$ Chadha is certainly no counterexample. There the Court concluded that $\S 244(\mathrm{c})(2)$ of the Immigration and Nationality Act-which authorized a unicameral legislative veto-was severable from the remainder of $\S 244$ and the Act as a whole. Id. The Court certainly did not hold that any putative statute adopted via the unconstitutional procedure set forth in $\$ 244(\mathrm{c})(2)$ could be severed into valid and invalid parts.

${ }^{126}$ Morrison, 529 U.S. at 627. Or consider Marbury, 5 U.S. (1 Cranch) 137, in which the Court treated (what it read as) the grant of original jurisdiction to issue writs of 
Of course, had Congress included a nonseverability clause in the Act, specifying that the invalidation of any provision would void the entire Act, the Court could have enforced such a clause, but it would have done so as a matter of nonconstitutional law. Absent such instruction from Congress, however, there is a working assumption that discrete bits of language enacted together may be invalidated separately if the constitutional infirmity is found in the content of only some of the statutory language.

So far, the practice of severing the unconstitutional bits of statutes from the constitutional bits does not appear to pose any difficulties for our conception of existence conditions. A problem arises from the fact that courts claim a power to sever not just unconstitutional statutory clauses but also unconstitutional applications. Suppose again that the plaintiff in Kimel or Garrett had been the victim of unconstitutional discrimination. One can imagine that the Court could have written an opinion that went something like this:

The statute as written fails the congruence and proportionality test, and therefore Congress lacked the authority to abrogate state sovereign immunity. Nonetheless, we presume that Congress intends unconstitutional provisions and applications of statutes to be severable from constitutional provisions and applications. ${ }^{127}$ Thus, we can sever so much of the statute that provides a damages remedy for permissible discrimination and uphold that portion of the statute which provides a remedy for impermissible discrimination of the sort presented here. So truncated, the statute satisfies the constitutional test and provides plaintiff with a valid remedy.

If this sort of procedure were allowed without restriction, all content-based existence conditions would function as application conditions (except that because they would "really" be existence conditions, they would necessarily be enforced even if one thought,

mandamus in $\$ 13$ of the Judiciary Act of 1789 as a nullity without saying or implying that the rest of the Act was invalid.

${ }^{127}$ See Chadha, 462 U.S. at 934-35; Champlin Ref. Co. v. Corp. Comm'n, 286 U.S. 210, 234-35 (1932) ("Unless it is evident that the legislature would not have enacted those provisions which are within its power, independently of that which is not, the invalid part may be dropped if what is left is fully operative as a law."); Adler, Rights Against Rules, supra note 35, at 145-52 (discussing partial rather than facial invalidation of statutes failing constitutional tests). 
contrary to Marshall's argument in Marbury, that application conditions should not be enforced). In any enumerated powers challenge, then, the Court would inquire whether (1) the text Congress enacted applies to the regulated conduct, and (2) the regulated conduct does in fact fall within the domain of conduct regulable by Congress, so that Congress could have regulated the conduct under a properly drawn statute. If (1) and (2) were satisfied, the Court would sever (or assume the severability of) the statute to the extent that it regulates nonregulable conduct, leaving intact a statute regulating the conduct at issue in the particular case simply because that conduct is regulable. This result would be equivalent to treating an enumerated power as stating a necessarily enforceable application condition.

Although courts do claim the power to sever not just unconstitutional language but also unconstitutional applications, ${ }^{128}$ this power is rather limited in practice and so does not convert all contentbased existence conditions into necessarily enforceable application conditions. That is the meaning, we think, of the longstanding principle that, notwithstanding the presumption of severability, courts will not re-write statutes in order to narrow and save them. To return to the Kimel and Garrett variations, neither the ADEA nor the ADA as written distinguishes between rational and irrational discrimination, and so "severing" the two categories would really require the Court first to graft such a distinction into the statute, a power the courts have typically disclaimed.

Moreover, some content-based constitutional tests are themselves inconsistent with a robust power of application severability. Thus, it is difficult to imagine how the congruence-andproportionality test could be applied coherently to the "application-severed" statute. The test asks whether the text Congress enacted was congruent and proportional to the record of constitutional violations Congress considered. Although it is conceivable that the Court could ask whether, by coincidence, the judicially truncated and rewritten text is congruent and proportionate to the record that was before Congress when it adopted the much broader statute, such an inquiry would be inconsistent with the spirit (and perhaps the letter) of the congruence-and-proportionality

\footnotetext{
${ }^{128}$ See Adler, Rights Against Rules, supra note 35, at 152-70.
} 
test, which focuses on the relation between an actual record and the actual statute Congress enacted. ${ }^{129}$ The same sort of relation is demanded by the Commerce Clause test for validity.

We have thus far argued in this Section that, given how they function in our constitutional culture, the enumerated powers are best read as stating existence conditions and that the possibility of severing unconstitutional provisions of statutes from constitutional provisions does not alter that conclusion. An unfettered judicial power to sever unconstitutional applications would convert the enumerated powers into necessarily enforceable application conditions, but the courts' power to sever unconstitutional applications is in fact limited, and thus is consistent with the view that the enumerated powers are full-fledged existence conditions. As for the other federalism provisions in the Constitution, which we shall now briefly examine, we conclude that some such provisions function as existence conditions while others function as application conditions.

In addition to empowering the federal government, the Constitution also contains federalism provisions that disempower the states in certain respects. For example, absent congressional consent, Article I, Section 10 prohibits a state from laying "any Imposts or Duties on Imports or Exports, except what may be absolutely necessary for executing its inspection Laws." ${ }^{130}$ Likewise, the affirmative grant of power to Congress to regulate interstate commerce has long been understood to contain a "dormant" prohibition on some forms of state regulation of interstate commerce. Under the modern test, the dormant commerce clause principally prohibits discriminatory and unduly burdensome regulations of interstate commerce. ${ }^{131}$

\footnotetext{
${ }^{129}$ For an argument that the congruence-and-proportionality test relies on a misunderstanding of congressional factfinding, see William W. Buzbee \& Robert A. Schapiro, Legislative Record Review, 54 Stan. L. Rev. 87 (2001).

${ }^{130}$ U.S. Const. art. I, $\S 10$, cl. 2.

${ }^{131}$ W. Lynn Creamery v. Healy, 512 U.S. 186, 192-94 (1994); New Energy Co. v. Limbach, 486 U.S. 269, 273-74 (1988) ("This 'negative' aspect of the Commerce Clause prohibits economic protectionism-that is, regulatory measures designed to benefit in-state economic interests by burdening out-of-state competitors. Thus, state statutes that clearly discriminate against interstate commerce are routinely struck down unless the discrimination is demonstrably justified by a valid factor unrelated to economic protectionism." (citations omitted)).
} 
These provisions operate as existence conditions. For example, a state tax that by its terms applies only to "out-of-state banks" is facially discriminatory and therefore, under the conventional approach, void. An otherwise properly enacted (under state constitutional standards) provision of state law containing such a tax is not a valid rule of law in light of the dormant commerce clause.

One might think that in other circumstances the dormant commerce clause functions as an application condition. Although the precedents in this area are complex and arguably incoherent, ${ }^{132}$ it can be said that whatever else it does, the antidiscrimination prong of the dormant commerce clause prohibits laws that, while neutral on their face and arguably enacted to serve legitimate state ends, have discriminatory effects. ${ }^{133}$ In fact, one might also think that "effects" tests always function as application conditions: unconstitutional effects, in this view, amount to unconstitutional applications of otherwise valid laws. Effects tests, however, can function as existence conditions. Constitutional effects tests sometimes take the following form: A law with the effect of $X$ is invalid, where $X$ may be principally advancing religion,,$^{134}$ placing a substantial obstacle in the path of a woman's efforts to obtain an abortion, ${ }^{135}$ or unduly

${ }^{132}$ See, e.g., Tyler Pipe Indus. v. Wash. State Dep't of Revenue, 483 U.S. 232, 260 (1987) (Scalia, J., dissenting) ("[A]pplications of the doctrine have, not to put too fine a point on the matter, made no sense."); Kassel v. Consol. Freightways Corp., 450 U.S. 662, 706 (1981) (Rehnquist, J., dissenting) (describing the doctrine as "hopelessly confused"); 1 Laurence H. Tribe, American Constitutional Law § 6-14, at 1104 (3d ed. 2000); Michael A. Lawrence, Toward a More Coherent Dormant Commerce Clause: A Proposed Unitary Framework, 21 Harv. J.L. \& Pub. Pol'y 395, 397-99 (1998).

${ }^{133}$ Associated Indus. v. Lohman, 511 U.S. 641, 654 (1994) ("[W]e repeatedly have focused our Commerce Clause analysis on whether a challenged scheme is discriminatory in "effect' ...."); id. at 653 ("[A] court need not inquire into the purpose or motivation behind a law to determine that in actuality it impermissibly discriminates against interstate commerce."); Bacchus Imps. v. Dias, 468 U.S. 263, 270 (1984) ("A finding that state legislation constitutes 'economic protectionism' may be made on the basis of . . discriminatory effect." (citations omitted)).

${ }^{1: 4}$ Zelman v. Simmons-Harris, 122 S. Ct. 2460, 2465 (2002) ("“The Establishment Clause of the First Amendment, applied to the States through the Fourteenth Amendment, prevents a State from enacting laws that have the "purpose" or "effect" of advancing or inhibiting religion." (citing Agostini v. Felton, 521 U.S. 203, 222-23 (1997))).

${ }^{135}$ Planned Parenthood v. Casey, 505 U.S. 833, 878 (1992) (O'Connor, Kennedy, \& Souter, JJ., plurality) ("Unnecessary health regulations that have the purpose or effect of presenting a substantial obstacle to a woman seeking an abortion impose an undue burden on the right [recognized in Roe v. Wade, 410 U.S. 113 (1973)]."). 
burdening interstate commerce. ${ }^{136}$ The invalid effects of the law render the law, not just the effects, unconstitutional. Each of the aforementioned constitutional prohibitions may also state an application condition under some circumstances, but this fact does not preclude the possibility that effects tests can function as existence conditions.

Constitutional provisions and doctrines can appear alternatively as existence conditions or application conditions depending upon the type of action to which they apply. Consider another federalism doctrine. The anti-commandeering principle of New York $v$. United States $^{137}$ and Printz v. United States ${ }^{138}$ operated, in the context of those cases, as an existence condition. As the Court interpreted the Tenth Amendment (and a free-floating federalism provision), Congress may not make a law specifically directing a state legislature to adopt a particular law or a state executive official to enforce a federal directive against a third party. Accordingly, Printz and New York are best read to mean that the challenged provisions of the Low-Level Radioactive Waste Policy Amendments Act and the Brady Handgun Violence Prevention Act were not valid rules of law.

One can nonetheless imagine circumstances in which the anticommandeering rule would appear to function as an application condition. Consider a hypothetical federal statute delegating authority to a federal administrative agency to issue "all orders necessary" to effectuate a statutory mandate that is clearly within some subject-matter area competence of the federal government, such as the interdiction of fissile materials moving in interstate or foreign commerce. Suppose that the federal agency orders a state energy regulatory commission to review power plant applications under a more stringent standard than the state commission would otherwise employ, and suppose further that the federal order, if contained in a federal statute, would violate Printz. It is clear from

\footnotetext{
${ }^{136}$ Gen. Motors Corp. v. Tracy, 519 U.S. 278, 287 (1997) ("The negative or dormant implication of the Commerce Clause prohibits state taxation that discriminates against or unduly burdens interstate commerce and thereby imped[es] free private trade in the national marketplace." (citations omitted) (quoting Reeves, Inc. v. Stake, 447 U.S. $429,437(1980))$ ).

${ }^{137} 505$ U.S. $144(1992)$.

${ }^{138} 521$ U.S. $898(1997)$.
} 
Printz that the anti-commandeering rule, as a limit on federal power, would apply to a federal agency no less than to Congress. In this context, however, insofar as the federal statute is concerned, the anti-commandeering rule operates as an application condition rather than as an existence condition. The law delegating power to the federal agency is valid, but the particular application of that law is not.

The foregoing example is hardly unique. In general, where a constitutional provision states either a subject-matter or "etiquette" limit on federal legislation, it will also state a similar limit on federal administrative action. That limit then functions as an existence condition for agency output and simultaneously as an application condition for the underlying statute. The agency output-a rule or an order-is void, but the congressional output - the statute authorizing the agency action-remains valid in that it continues to authorize the agency to act when the latter does not run afoul of the subject-matter or etiquette limit.

More broadly still, as these last examples illustrate, what appears to be a single constitutional provision or doctrine might actually be best understood as stating multiple constitutional rules-some of them existence conditions and others application conditionsdepending upon the context. We return to this point in our discussion of individual rights.

\section{Individual Rights}

Professor Ronald Dworkin famously characterized rights in American constitutional law as "trumps" that block otherwise valid exercises of governmental power. ${ }^{139}$ To the extent that Professor Dworkin's view makes rights absolute bars to balancing and other consequentialist calculations, it fails to capture the degree to which constitutional rights can be overridden by a sufficiently strong competing end. ${ }^{240}$ American constitutional rights are more accurately described as "shields" that deflect weak and medium

\footnotetext{
${ }^{139}$ See sources cited supra note 49.

${ }^{140}$ See Michael C. Dorf, Truth, Justice, and the American Constitution, 97 Colum. L. Rev. 133, 155-56 (1997) (reviewing Dworkin, Freedom's Law, supra note 36, and Dennis Patterson, Law and Truth (1996)).
} 
strength justifications but succumb to very strong ones. ${ }^{141}$ Yet either metaphor-rights as trumps or rights as shields-suggests that rights typically function as application conditions: Each person walks around protected by either an infinitely or merely very strong shield that knocks out either all or most laws infringing her protected rights.

This picture-which we think dominates the constitutional imagination-perhaps explains why it is natural to think that constitutional rights cases invariably fall within the model of the example discussed in Part I: Widget Inc.'s objection that the Wetlands Preservation Act takes its property without just compensation in violation of the Fifth Amendment, even though the Act itself is valid. Many constitutional rights claims do seem to fit this picture. However, the picture is misleading, or at least incomplete. ${ }^{142}$ Constitutional rights sometimes function as existence conditions also, and, as is true of the dormant commerce clause and the anti-commandeering principle, the same individual right sometimes functions variously as an existence condition or an application condition. Parsing individual rights provisions and doctrines into existence and application conditions sheds light on the distinction between facial and as-applied rights claims, and further clarifies what is at stake in calls to remove the courts from constitutional adjudication of rights cases.

Various constitutional rights provisions operate much like the Takings Clause in Widget's case-that is, as application conditions. Consider the requirement drawn from the Fourth Amendment that, absent exigent circumstances or some other exception, the police must obtain a warrant based upon probable cause in order to support a search or seizure. ${ }^{143}$ This constitutional doctrine constrains police (and arguably other official) conduct, rather than defining what counts as state or federal law. Likewise, to give additional examples, the Fifth Amendment right to an indictment by a grand jury in federal criminal prosecutions, the Sixth Amendment right to a speedy trial, the Seventh Amendment right to a civil jury

\footnotetext{
${ }^{141}$ See Frederick Schauer, A Comment on the Structure of Rights, $27 \mathrm{Ga}$. L. Rev. 415, 429-30 (1993).

${ }_{142}$ See Adler, Rights Against Rules, supra note 35, at 6-12.

${ }^{143}$ See, e.g., Almeida-Sanchez v. United States, 413 U.S. 266, 273 (1973); Sibron v. New York, 392 U.S. 40, 62-66 (1968).
} 
trial in federal cases, and the Eighth Amendment right against cruel and unusual punishment all focus on what happens to particular persons in particular situations. They do not (necessarily) figure into a judge's identification of the law that she must apply.

This is not to say that the aforementioned constitutional provisions could never be invoked to challenge particular laws. A law authorizing a violation of any of these provisions could be held unconstitutional on that basis, but, in doing so, a court would be, in effect, employing a time-saving device. Rather than await each unconstitutional search, indictment, bench trial, and disproportionate sentence to occur, a court that holds a law invalid insofar as it authorizes unconstitutional action substitutes a wholesale remedy for a retail one. ${ }^{144}$

Current doctrine purports to disfavor this sort of wholesale invalidation of laws on the basis of aggregating retail violations of application conditions. Thus, in United States $v$. Salerno, the Court declared that it would only invalidate the Bail Reform Act of 1984 as inconsistent with the Eighth Amendment's Excessive Bail Clause if there were "no set of circumstances" in which the Act could be constitutionally applied. ${ }^{145}$ As each of us has argued at some length, there are reasons to doubt both the wisdom of the Salerno rule and its accuracy as a statement of the Court's practice. ${ }^{146}$ Yet even taking Salerno on its own terms, it should be clear that the "no set of circumstances" rule only operates-or at least that it should only operate-in cases in which a law (or general policy having the effect of law) is challenged as inconsistent with an application condition. If, by contrast, the constitutional provision invoked sets forth an existence condition, an evaluation of individual applications of the statute is irrelevant to the question whether

${ }^{144}$ Application conditions like those discussed in the previous two paragraphs of text might also function, in certain circumstances, as existence conditions for certain kinds of legal utterances. For example, the failure to respect the Sixth or Seventh Amendment right to jury trial might render void a judgment or decree from the resulting bench trial (if the objection was preserved). Likewise, the Fourth Amendment's requirement that a search warrant state facts giving rise to probable cause-or at least facts that a reasonable police officer acting in good faith could think give rise to probable cause, see United States v. Leon, 468 U.S. 897, 922-23 (1984)-might be an existence condition for the warrant.

${ }^{145} 481$ U.S. 739, 745 (1987).

${ }^{146}$ See Adler, Rights Against Rules, supra note 35, at 154-58; Dorf, Facial Challenges, supra note 35 , at 236-39. 
the challenged law is valid-except to the extent that, as with the effects tests under the Establishment Clause, the abortion decisions, and the dormant commerce clause, the question whether a putative law satisfies the relevant existence condition itself depends upon the impact of the putative law. ${ }^{147}$

To an extent that may be surprising given the dominance of the picture encapsulated by the Widget case, constitutional rights set forth existence conditions. There is no constitutional right to burn a flag, ${ }^{148}$ but the Free Speech Clause of the First Amendment invalidates laws targeting the communicative impact of flagburning ${ }^{149}$ There is no constitutional right to use peyote in a religious ritual, but the Free Exercise and Establishment Clauses of the First Amendment invalidate laws singling out religiously motivated peyote use..$^{150}$ No constitutional right entitles eighteen-totwenty-one-year-old males to purchase $3.2 \%$ beer, but a law granting that privilege to female but not male eighteen-to-twenty-oneyear-olds violates the Equal Protection Clause of the Fourteenth Amendment. ${ }^{151}$ In each of these examples, the relevant constitutional provision operates as an existence condition, not an application condition.

This is not to say that the relevant constitutional provisions do not or could not also operate as application conditions in other contexts. The First Amendment provides some (albeit weak) pro-

${ }^{147}$ Our position is thus close to that of Professor Marc Isserles, who distinguishes between an overbreadth challenge, "which predicates facial invalidity on some aggregate number of unconstitutional applications of an otherwise valid rule of law," and "a 'valid rule facial challenge,' which predicates facial invalidity on a constitutional defect inhering in the terms of the statute itself, independent of the statute's application to particular cases." Marc E. Isserles, Overcoming Overbreadth: Facial Challenges and the Valid Rule Requirement, 48 Am. U. L. Rev. 359, 363-64 (1998). However, our categories are not entirely congruent. Unlike Isserles, we do not insist that the test for validity of a statute itself-what we term an existence condition-must proceed without regard to a statute's applications.

${ }^{148}$ For example, an arsonist who starts a fire with a burning flag could be punished under an arson prohibition. See Adler, Rights Against Rules, supra note 35, at 3-4 (discussing Texas v. Johnson, 491 U.S. 397 (1989)).

${ }^{149}$ See Johnson, 491 U.S. at 420.

${ }^{150}$ Compare Employment Div. v. Smith, 494 U.S. 872 (1990) (upholding religiously neutral prohibition on drug use despite lack of exemption for religiously motivated use), with Church of the Lukumi Babalu Aye, Inc. v. City of Hialeah, 508 U.S. 520 (1993) (invalidating prohibition on animal sacrifice that targeted Santeria church).

${ }^{151}$ Craig v. Boren, 429 U.S. 190 (1976). 
tection to particular speech-acts proscribed under content-neutral laws that may be valid in most circumstances. ${ }^{152}$ Likewise, Congress, some constitutional scholars, and a minority of the current Supreme Court Justices all take the view that the Free Exercise Clause shields some religiously motivated conduct from regulation under otherwise valid rules of law. ${ }^{153}$ Free-speech doctrine regarding content-neutral laws and the various proposals to exempt religiously motivated conduct from generally applicable laws could be understood as stating existence conditions, with the remedy of partial invalidation for those laws failing the relevant tests. Alternatively, a regime of free-speech or free-exercise exemptions from otherwise valid rules could be viewed as setting forth application conditions.

But even assuming that the application-conditions view is correct, this would hardly negate the fact that constitutional rights also set forth existence conditions. No one argues that the First Amendment should be read to protect against incidental burdens on protected conduct and not against laws that target rights. According to critics of the Court's free-exercise doctrine, the Free Exercise Clause-like the dormant commerce clause and the anticommandeering doctrine-should be read as sometimes acting as an application condition and at other times acting as an existence condition. In other words, the debate in the peyote case and similar cases is not about whether constitutional rights should ever be read as existence conditions; it is about whether they should ever be read as anything more than existence conditions.

Consider three arguments for viewing particular rights as exclusively providing protection against rules rather than also shielding conduct. First, the majority in Employment Division $v$. Smith ${ }^{154}$ ad-

${ }^{152}$ Nominally, intermediate scrutiny applies to such laws, but in practice the Supreme Court applies a more deferential approach. See Michael C. Dorf, Incidental Burdens on Fundamental Rights, 109 Harv. L. Rev. 1175, 1200-10 (1996) [hereinafter Dorf, Incidental Burdens].

${ }_{153}$ After a majority of the Supreme Court concluded that there was no such constitutional protection, Smith, 494 U.S. at 890, Congress disagreed and enacted the Religious Freedom Restoration Act of 1993-invalidated in Flores, 521 U.S. 507-to override Smith. For academic criticism of the Smith decision, see, for example, Michael W. McConnell, Free Exercise Revisionism and the Smith Decision, 57 U. Chi. L. Rev. 1109 (1990); Kathleen M. Sullivan, Religion and Liberal Democracy, 59 U. Chi. L. Rev. 195, 215-19 (1992).

${ }^{1.4} 494$ U.S. at $877-82$. 
vances the claim, traceable in one form to Professor Friedrich Hayek, ${ }^{155}$ that a commitment to the rule of law does not permit judges (or other officials) to make rights-based exceptions to otherwise valid general laws. Second, it can be argued that widely shared and deeply rooted understandings of liberty and equality are best implemented by constitutional doctrine that conceptualizes judges' activity in protecting (most) rights as the repeal or revision of constitutionally defective rules. ${ }^{156}$ Finally, particular constitutional language draws attention to laws rather than applications: "No Bill of Attainder or ex post facto Law shall be passed"; ;" "Congress shall make no law" establishing religion, prohibiting free exercise, or abridging freedom of speech, the press, or assembly. ${ }^{158}$ If this last point counts in favor of treating these provisions as existence conditions, however, then by negative implication, it counts against treating provisions containing no similar language as existence conditions.

Were we to enter the debate over whether constitutional rights should ever be read as stating application conditions, we would argue that they sometimes should be so read. ${ }^{159}$ But we do not mean here to take a position on which rights-conferring constitutional provisions and doctrines are best read as existence conditions, which are best read as application conditions, and which are best

${ }^{155}$ See Michael C. Dorf, The Heterogeneity of Rights, 6 Legal Theory 269, 295-96 (2000) [hereinafter Dorf, Heterogeneity of Rights] (discussing a view set forth in Friedrich A. Hayek, The Constitution of Liberty 148-61 (1960)).

${ }^{156}$ See Adler, Rights Against Rules, supra note 35.

${ }^{157}$ U.S. Const. art. I, $\$ 9$, cl. 3.

${ }_{158}^{158}$ Id. amend. I.

${ }^{159}$ Michael C. Dorf, God and Man in the Yale Dormitories, 84 Va. L. Rev. 843 (1998); see Dorf, Incidental Burdens, supra note 152. The statement in the text is, perhaps despite appearances, consistent with the prior work of both authors. In "The Heterogeneity of Rights," supra note 141, at 270, Dorf took aim at the following statement in Adler's "Rights Against Rules": "Constitutional rights in our own legal world are structured, not as shields around particular actions, but as shields against particular rules." Adler, Rights Against Rules, supra note 35, at 13. Dorf disagreed with Adler's statement to the extent that it implied that all constitutional rights are or should be rule-dependent. However, as Adler then made clear, his was an argument about how to understand, and what implications to draw from, the wide range of constitutional rights that are in fact rule-dependent; he was not claiming that all constitutional rights are or should be rule-dependent. See Adler, Personal Rights, supra note 35, at 344 (describing the "Rule-Dependence Thesis . . as the thesis that some constitutional scenarios are rule-dependent"). 
read as existence conditions in some circumstances and application conditions in others. Our point is simply that, despite what one might think based upon the picture conveyed by the Widget case, constitutional rights do not invariably take the form of application conditions; rather, they frequently take the form of existence conditions.

Putting aside the picture conveyed by the Widget hypothetical would result in a view of rights closer to the one that was widely held at the Founding. The drafters of the Constitution had, as their principal aim, the strengthening of the federal government, yet they also sought to limit the newly strengthened government so that it would not threaten their "rights." We use quotation marks here to connote a certain fuzziness about the way the Founding generation conceptualized rights. For one thing, the term "right" was frequently used indiscriminately to refer to the protection of individuals, states, and other collective entities ${ }^{160}$ This particular fuzziness has been a source of consternation for scholars, lawyers, and judges trying to make sense of the Second Amendment. ${ }^{161}$

Nor did the Founding generation think it especially important to define particular rights, as the Federalists' initial opposition to a Bill of Rights reveals. Hamilton, Madison, and other leading Federalists erroneously believed that the Constitution's failure to grant to Congress the power to infringe specific liberties, such as the freedom of speech, was sufficient to protect those liberties. ${ }^{162}$ They

${ }^{160}$ See Richard A. Primus, The American Language of Rights 85 (1999) ("Bearers of rights [at the Founding] included legislatures, governments, cities, colonies, countries, specific communities, and 'the people' as a collective entity distinct from individuals.").

${ }^{161}$ Compare Silveira v. Lockyer, 312 F.3d 1052, 1061 (9th Cir. 2002) (concluding that the "collective rights model... provides the best interpretation of the Second Amendment"), with United States v. Emerson, 270 F.3d 203, 218-29 (5th Cir. 2001) (reaching the opposite conclusion that the Second Amendment protects an individual's right to keep and bear arms).

${ }^{162}$ See, e.g., The Federalist No. 84, at 513 (Alexander Hamilton) (Clinton Rossiter ed., 1961) ("[W]hy declare that things shall not be done which there is no power to do?"); Letter from James Madison to Thomas Jefferson (Oct. 17, 1788), in The Origins of the American Constitution 367, 369 (Michael Kammen ed., 1986) (expressing Madison's view that the omission of a Bill of Rights was unimportant because, among other things, "the rights in question are reserved by the manner in which the federal powers are granted"); James Wilson, Speech at a Public Meeting in Philadelphia (Oct. 6, 1787), in Federalists and Antifederalists: The Debate Over the Ratification of the Constitution 166, 167 (John P. Kaminski \& Richard Leffler eds., 2d ed. 1998) ("[I]t 
seem to have overlooked the possibility that a measure-such as the prohibition of interstate sales of newspapers critical of the government-could fall within a general power but nonetheless infringe a right. ${ }^{163}$

The Framers' seemingly sloppy thinking about rights is also reflected in the language of the Bill of Rights that was ultimately adopted. The First Amendment takes the form of a prohibition on lawmaking by Congress, but other provisions establish (or recognize) "rights." The Second, Fourth, Ninth, and Tenth Amendments refer to "the people," whereas the Fifth Amendment (twice) refers to what the government may not do to any "person." 165 Are these distinctions important? A sufficiently ingenious and hardworking constitutional archeologist such as Professor Akhil Amar can find hidden meanings in these particular word choices, ${ }^{166}$ thereby posing an interesting question about the extent to which constitutional interpreters should strive for what Professor Christopher Eisgruber (pejoratively) terms "aesthetic" value in trying to make the greatest sense of textual intricacies. ${ }^{167}$ Putting that debate to one side, however, it should be emphasized that the phrasing of the original Constitution and Bill of Rights may appear to contemporary readers as haphazard or Delphic because most of us tend to view the document through the lens of modern conceptions of rights. To members of the Founding generation, it was natural to use the term "rights" somewhat loosely because they viewed the recitation of rights and the enumeration of powers as mutually re-

would have been superfluous and absurd to have stipulated with a federal body of our own creation, that we should enjoy those privileges, of which we are not divested either by the intention or the act, that has brought that body into existence.").

${ }^{163}$ See Dorf, Incidental Burdens, supra note 152, at 1190-92. We use "seem" here, however, because the original Constitution did, of course, contain provisions in Article I, $\S 9$ that only make sense on the assumption that a general grant of power can be used to infringe a right: The affirmative powers nowhere expressly authorize Congress to suspend the privilege of the writ of habeas corpus or to enact ex post facto laws or bills of attainder, yet the Constitution still prohibits these practices. See U.S. Const. art. I, $\S 9$, cls. $2-3$.

${ }^{164}$ U.S. Const. amends. 1I, IV, $1 \mathrm{X}, \mathrm{X}$.

${ }^{165}$ Id. amend. V.

${ }^{166}$ See Akhil Reed Amar, Intratextualism, 112 Harv. L. Rev. 747 (1999). But see Adrian Vermeule \& Ernest A. Young, Hercules, Herbert, and Amar: The Trouble with Intratextualism, 113 Harv. L. Rev. 730 (2000).

${ }^{167}$ Christopher L. Eisgruber, The Living Hand of the Past: History and Constitutional Justice, 65 Fordham L. Rev. 1611, 1617 (1997). 
inforcing checks that served the interest of limiting the reach of government. ${ }^{168}$ They frequently viewed rights-no less than powers-as expressing limits on the sorts of laws that Congress could enact, that is, as setting forth existence conditions.

To summarize, notwithstanding what may appear to be the paradigmatic nature of the Widget case, the circumstances in which courts are asked to adjudicate rights claims frequently require them to treat the relevant rights provision or doctrine as setting forth an existence condition. We conclude this Section with two further observations.

First, observe an apparent irony. From the perspective of democratic theory, judicial enforcement of a constitution poses the fewest problems when the courts invoke the constitution to block administrative as opposed to legislative action. ${ }^{169}$ Even the English legal system in the heyday of parliamentary supremacy recognized an ultra vires doctrine, and judicial review skeptics, such as Professor Jeremy Waldron, seem more comfortable with the concept of judicial enforcement of constitutional limits against executive and administrative action..$^{170}$ Yet our analysis suggests that courts can more readily justify nonenforcement of constitutional limits on executive and administrative action than of legislative action-for constitutional limits on the former will frequently take the form of application conditions with respect to the underlying statutes, ${ }^{171}$ whereas limits on decisions taken by the legislature typically go to the validity of the legislation, and are thus existence conditions. The irony dissolves, however, when one recalls that the same constitutional provision may function simultaneously as an application

${ }^{168}$ See Randy E. Barnett, Introduction: James Madison's Ninth Amendment, in The Rights Retained by the People: The History and Meaning of the Ninth Amendment 1, 14-19 (Randy E. Barnett ed., 1989).

${ }^{169}$ See Adler, Judicial Restraint, supra note 45, at 764-71; cf. Henry P. Monaghan, Marbury and the Administrative State, 83 Colum. L. Rev. 1, 1 (1983) (noting the need for judicial review of agency decisionmaking to prevent the constitutional scheme from going "seriously awry").

${ }^{170}$ See Waldron, supra note 7.

${ }^{171}$ This may not always be true. Consitutional limits on executive and administrative actions sometimes take the form of freestanding existence conditions that do not, apparently, function as application conditions for statutes. For example, various doctrines drawn from $\S 7$ of Article I, the Take Care Clause, the Appointments Clause, and the general principle of separation of powers (discussed above in Section II.B) set forth existence conditions for administrative bodies themselves. 
condition with respect to legislation authorizing administrative action and as an existence condition with respect to the administrative action itself. As an example, the Printz anti-commandeering rule functions as an application condition with respect to a (barely hypothetical) statute authorizing the Justice Department to "investigate allegations of terrorism" when the Department attempts to implement the statute by ordering state law enforcement officials to question men of Middle Eastern origin, but Printz functions as an existence condition for the Department's order itself. More generally, where existence conditions render agency output void, the conscientious judge truly has no choice but to enforce such conditions. In other words, this account does not make the enforcement of constitutional limits on agency action more "optional" than the enforcement of similar limits on legislation.

Second, our analysis narrows the scope of legitimate disagreement about when courts should strike down legislation on its face. A court faced with a rights (or other) challenge based on an existence condition has no occasion to apply the Salerno test. A successful challenge based on an existence condition will mean that the Salerno test for unconstitutionality is automatically satisfied: A putative law that is not in fact valid-that is, in the traditional formulation, a nullity-cannot be constitutionally applied under any set of circumstances. ${ }^{172}$

Accordingly, it should be uncontroversial that courts mustabsent epistemic and related considerations and subject to severance for some constitutional tests-facially invalidate laws that fail existence conditions. The debate about facial-versus-as-applied litigation should focus on the question of the circumstances in which courts can facially invalidate laws for failing to satisfy application conditions. That debate, as one of us has argued at length elsewhere is best understood as turning on questions of severability. ${ }^{173}$

\footnotetext{
${ }^{172}$ See Dorf, Heterogeneity of Rights, supra note 155, at 286 ("For example, in some separation-of-powers cases, the very existence of a rule- or policy-making body will be deemed unconstitutional, thus rendering all of its actions invalid.").

${ }^{173}$ See Dorf, Facial Challenges, supra note 35, at 249-51 (arguing that the proper evaluation of a facial challenge turns on whether constitutional principles override the presumption that invalid provisions and applications of laws are severable from valid provisions and applications); Dorf, Heterogeneity of Rights, supra note 155, at 279
} 
Whether to permit severability is principally a matter of statutory interpretation, but the inquiry may also be constrained by constitutional factors. ${ }^{174}$ To the extent that one concludes that the Constitution itself forbids severability (that is, requires facial invalidation) as a remedy for some aggregation of unconstitutional applications-as in the standard view of the First Amendment overbreadth doctrine-the application condition has been transformed into an existence condition as well. Regarding this sort of doctrine, we would say that one existence condition for laws subject to the overbreadth doctrine is that such laws not admit of too many unconstitutional applications. ${ }^{175}$ In short, as demonstrated in the previous Section, the possibility that courts may sever valid from invalid clauses and some applications of laws can, in certain contexts, blur the distinction between existence and application conditions. ${ }^{176}$

Notwithstanding the possibility of such blurring, the distinction between existence conditions and application conditions remains serviceably clear-and important. We turn next to the question of how to make sense of doctrines, like the enrolled bill doctrine, the political question doctrine, and rational basis review, that appear to underenforce or entirely fail to enforce what we have argued are existence conditions that the courts must necessarily fully enforce.

(arguing "that understanding the facial challenges debate as a debate about when courts may sever portions and applications of statutes would clarify the real stakes").

${ }^{174}$ See Dorf, Heterogeneity of Rights, supra note 155, at 281-90; Richard H. Fallon, Jr., As-Applied and Facial Challenges and Third-Party Standing, 113 Harv. L. Rev. 1321,1351 (2000) ("[L]imits on severability are aspects of the particular constitutional tests developed by the Supreme Court to enforce specific constitutional provisions ....").

${ }^{175}$ Professor Henry Monaghan's important article on the subject expressed a somewhat different view of how the overbreadth doctrine functions as an existence condition. He argued that the doctrine could be explained as a consequence of the constitutional rule that strict scrutiny-a requirement that the law's effects closely match a compelling interest-applies to laws abridging First Amendment freedoms. See Henry Paul Monaghan, Overbreadth, 1981 Sup. Ct. Rev. 1, 36-39. Although we do not fully agree with Professor Monaghan's approach, see Dorf, Facial Challenges, supra note 35 , at $243-44 \& 243 \mathrm{n} .29$, his core insight retains much explanatory force.

${ }^{176}$ See Dorf, Heterogeneity of Rights, supra note 155 , at 286 ("[S]everability can blur the distinction between, on the one hand, overbreadth and related doctrines, and, on the other, valid-rule facial challenges."). 


\section{UNDERENFORCEMENT OF EXISTENCE CONDITIONS}

In Part I, we argued that a constitutional existence condition is necessarily fully enforced by a legally conscientious court, insofar as the type of law whose existence hinges on the condition is legally relevant to the court's decision. In Part II, we argued that a wide range of constitutional provisions are existence conditions for federal and, to a lesser extent, state law. We now consider and defuse some apparent counterexamples to our claims: judicial devices such as the "enrolled bill" doctrine, the "political question" doctrine, "rational basis" review, and others by which courts seemingly underenforce existence conditions.

\section{A. Enrolled Bill Doctrine}

The "enrolled bill" doctrine ("EB"), announced by the Court in the 1892 case of Field v. Clark" and still good law, presents the starkest challenge to our claims-for EB apparently requires the underenforcement of Article I, Section 7 itself, the clearest case of a constitutional existence condition. In Field, an administrative agency had imposed duties on various importers pursuant to the Tariff Act of October 1, 1890, as set forth in the enrolled bill: the document signed by the Speaker of the House and the President of the Senate, which each asserts to have been approved by his respective house, and which is forwarded to the President for his signature and thence to statutory archives kept by the Secretary of State. ${ }^{178}$ It is from these archives that the Statutes at Large are, in turn, copied. The importers challenged the assessed duties, claiming that the "Tariff Act" on which the agency had relied was not law because the Congressional Record and House and Senate committee reports demonstrated that its language differed from the bill actually passed by Congress. The Supreme Court rejected this claim. It held that the "enrolled bill" is conclusive evidence of the content of a statute, that courts may not look to the Congressional Record or other extrinsic evidence tending to show that

${ }^{177} 143$ U.S. 649 (1892); see also United States Nat'l Bank v. Indep. Ins. Agents, 508 U.S. 439, 455 n.7 (1993) (limiting Field but not questioning its applicability within limited domain); United States v. Munoz-Flores, 495 U.S. 385, 391 n.4 (1990) (same).

${ }^{178}$ Field, I43 U.S. at 667-68. 
some other statutory language was what Congress really enacted. The Court stated:

The signing by the Speaker of the House of Representatives, and by the President of the Senate, in open session, of an enrolled bill, is an official attestation by the two houses .... through their presiding officers, to the President, that a bill ... has received, in due form, the sanction of the legislative branch of the government.... And when a bill, thus attested, receives his approval, and is deposited in the public archives, its authentication as a bill that has passed Congress should be deemed complete and unimpeachable .... The respect due to coequal and independent departments requires the judicial department to ... accept, as having passed Congress, all bills authenticated in the manner stated: leaving the courts to determine, when the question properly arises, whether the act, so authenticated, is in conformity with the Constitution. ${ }^{179}$

A document is not a statute unless it has "passed the House of Representatives and the Senate," in accordance with Article I, Section 7, Clause 2. "Passage" is standardly understood to mean being approved by a majority of a quorum of each house. ${ }^{180}$ The Constitution explicitly states that a majority of a house makes a quorum; it does not state explicitly that "passage" equals approval by a majority of the quorum, and there may be some interpretive flexibility there. But that flexibility is not so great as to mean that a document approved only by the Speaker of the House and President of the Senate, each with a quorum present, has "passed" Congress for constitutional purposes and is therefore a full-fledged statute once signed by the President. The Court in Field did not gainsay this point; it did not offer a radically minimal reading of constitutional bicameralism: "There is no authority in the presiding officers of the House of Representatives and the Senate to attest by their signa-

\footnotetext{
${ }^{179}$ Id. at 672.

${ }^{180}$ See, e.g., United States v. Ballin, 144 U.S. 1, 6 (1892) ("[T]he general rule of all parliamentary bodies is that, when a quorum is present, the act of a majority of the quorum is the act of the body. This has been the rule for all time, except so far as in any given case the terms of the organic act under which the body is assembled have prescribed specific limitations .... No such limitation is found in the Federal Constitution, and therefore the general law of such bodies obtains.").
} 
tures ... any bill not passed by Congress." ${ }^{181}$ What, then, justifies EB?

Let us bracket, for now, two possible justifications for EB and other supposed underenforcement doctrines. The first invokes the hierarchical authority of the Supreme Court. On this view, the Court functions in effect as a constitutional legislator vis-à-vis the lower federal courts. The Court announces doctrines that "implement" constitutional provisions, including existence conditions; the lower courts apply these doctrines, not the underlying constitutional provisions, in determining whether various types of laws exist and in resolving other constitutional issues that arise in adjudication. If this picture of the Supreme Court's role is correct, ${ }^{182}$ and if the Supreme Court can take account of administrative costs, error costs, transparency, settlement, and other such "institutional" considerations in shaping constitutional doctrine, then we have a ready explanation for EB. By "institutional" considerations, we mean the various considerations that (as a general normative or moral matter) weigh against nondeferential judicial enforcement of constitutional norms-the sorts of considerations cited by Professors Mark Tushnet, Paul Brest, Lawrence Sager, and other scholarly proponents of underenforcement. ${ }^{183}$ To quote the Court in Field once more:

The evils that may result from the recognition of the principle that an enrolled act ... is conclusive evidence that it was passed by Congress, according to the forms of the Constitution, would be far less than those that would certainly result from a rule making the validity of congressional enactments depend upon the

${ }^{181}$ Field, 143 U.S. at 669.

${ }^{182}$ Explaining the source and nature of lower courts' obligation to follow Supreme Court precedent rather than their own best judgment about what the Constitution and other sources of law require turns out to be more difficult than one at first might think. See Evan H. Caminker, Precedent and Prediction: The Forward-Looking Aspects of Inferior Court Decisionmaking, 73 Tex. L. Rev. 1, 4-5 (1994) (asking whether "inferior courts [should] consider themselves constrained only by prior superior court rulings .... or [whether] inferior courts [should] consider the implications of predictable future superior court rulings as well"); Dorf, Prediction, supra note 81 (critiquing a prediction-based theory of lower court decisionmaking).

${ }^{183}$ See Tushnet, supra note 7, at 54-71; Paul Brest, The Conscientious Legislator's Guide to Constitutional Interpretation, 27 Stan. L. Rev. 585, 588-99 (1975); Lawrence Gene Sager, Fair Measure: The Legal Status of Underenforced Constitutional Norms, 91 Harv. L. Rev. 1212, 1217-28 (1978). 
manner in which the journals of the respective houses are kept by the subordinate officers charged with the duty of keeping them. ${ }^{184}$

Absent EB, litigation costs would rise, as courts look to legislative journals to determine what texts were really enacted; courts would sometimes mistakenly credit the journal rather than the enrolled bill; a judicial practice of looking to journals would give legislators an incentive to insert into those records provisions that were not really passed by Congress, and Congress would have to put in place costly procedural "countermeasures" to prevent this kind of fabrication; and looking to journals would also increase uncertainty among the population as to the content of the law. On a certain controversial view of the Supreme Court's role, these sorts of prudential factors license the Court to create general doctrines that deviate from the underlying constitutional provisions-for example, to establish EB as doctrine even though a text is not really a statute unless passed by a majority of a quorum of each house. For now, however, let us consider whether EB can be justified in more mundane terms.

A second possible justification for $E B$, which we shall also bracket for now, points to Congress's power to structure adjudication. In general, Congress has the power to define and limit the types of nonconstitutional law that federal judges may consider. ${ }^{185}$ Imagine that Congress writes the following provision into the Judiciary Act:

(1) Federal courts shall consider claims and defenses arising under federal "shmatutes," as well as claims and defenses arising under federal statutes, other sources of federal law, and state law.

(2) A "shmatute" is a document approved by the President of the Senate and the Speaker of the House, and signed by the President.

${ }^{184}$ Field, 143 U.S. at 673.

${ }^{185}$ Webster v. Doe, 486 U.S. 592, 599-601 (1988); Henry M. Hart, Jr., The Power of Congress to Limit the Jurisdiction of Federal Courts: An Exercise in Dialectic, 66 Harv. L. Rev. 1362, 1401 (1953). 
(3) "Shmatutes" shall be on a par with statutes. Common law rules, agency regulations, and all other law is trumped by "shmatutes," just as by statutes. Further, a later "shmatute" trumps an earlier statute (or an earlier "shmatute").

The general idea here is that, given some type of law hinging on some constitutional existence condition, Congress can provide for (and make relevant to adjudication) some novel type of law lacking that existence condition. As an explanation of EB, this strategy probably fails: INS $v$. Chadha and other such separation-of-powers cases $^{186}$ make clear that Congress could not empower the Speaker and Senate President to create nonstatutory law ("shmatutes"), let alone give this novel kind of law parity with statutory law. In other contexts, however, the "congressional control" strategy for explaining underenforcement may be plausible.

Placing to one side this strategy and also the notion of the Court as constitutional legislator, is there any satisfying explanation for EB? To focus the issue, imagine a federal district court, operating under a provision of the Judiciary Act obliging it to hear "those and only those claims that arise under federal statutes," and adjudicating in a pre-Field world in which the Court has neither adopted nor negated EB and no Supreme Court doctrine is on point. Smith sues Acme, claiming a violation of the toxics provision of the "Safe Workplaces Act" and appending a copy of the enrolled bill to his complaint. Acme answers, citing the Congressional Record and claiming that the toxics provision was not in the version of the Act passed by Congress. Should the court follow EB (not qua Supreme Court doctrine, but qua its own understanding of the Constitution), ignore Acme's evidence, and determine that the toxics provision is really part of the Act?

One possible justification for $\mathrm{EB}$, in this posture, is epistemic. The district court (1) believes that a text must be approved by a majority of a quorum of each house (and signed by the President) to be a statute, and (2) believes that the Speaker of the House and Senate President are robust experts as to what their respective houses have approved. A robust expert on some matter is someone whose statements are conclusive (or to use the terminology popu-

${ }^{186}$ See, e.g., Bowsher v. Synar, 478 U.S. 714 (1986); Buckley v. Valeo, 424 U.S. 1 (1976). 
lar among some philosophers, "exclusionary") even in the face of contrary evidence. ${ }^{187}$ Whenever a trained astronomer, in apparently full possession of her faculties, points to some star and tells you its name, you might rationally believe her, even if based on testimonial evidence from non-astronomers or on your own research you would otherwise believe its name is different. Similarly, it might (in many situations) be epistemically reasonable for judges to take the presiding officers of legislative bodies as robust experts with respect to the content of laws promulgated by those bodies. A judge who follows the views of someone she takes to be a robust expert as to the content of some law is not "underenforcing" existence conditions for that law; rather, her beliefs about the satisfaction of those conditions track the statements of the robust experts, and she is sensitive to her beliefs thus derived.

The problem with this epistemic account of EB is that it has limited range. The district judge acts reasonably in taking the Speaker of the House and Senate President as robust experts only if (the judge believes that) their epistemic capacities are unimpaired in various ways. If the astronomer is obviously drunk, or "identifying" the star in a context where it is unreasonable to believe him sincere (on April Fools' Day, with lots of winks and smiles), then his identification is not reasonably taken as conclusive evidence of the name. The same is true for the legislative leaders. If Acme alleges in its answer that the Speaker is one hundred years old and has Alzheimer's disease, or that he has been blackmailed by the Workers' Party into enrolling the toxics provision despite nonpassage by the House, the district court fully enforcing the standard, majoritarian understanding of Article I, Section 7 should take evidence as to the truth of these expertise-defeating allegations and-if convinced - should depart from EB and look to the Congressional Record or other evidence to determine what version of the Safe Workplaces Act really passed Congress. But EB precludes this: Neither EB in the form announced by Field, nor in the form reaffirmed by the modern Court, contains exceptions for incapacity, in-

${ }^{187}$ See Donald H. Regan, Authority and Value: Reflections on Raz's Morality of Freedom, 62 S. Cal. L. Rev. 995, 1001-18 (1989) (providing an account of law's authority that involves second-order reasons for belief). 
sincerity, corruption, or other epistemic failures on the part of the enrolling officers.

Would anything warrant the district court in following EB in this situation, where the epistemic justification runs out? As already mentioned, existence conditions might be perspectival. ${ }^{188}$ This account of EB and, more generally, of putative underenforcement does not invoke the controversial notion of the Court as constitutional legislator, nor does it invoke congressional control of adjudication, that is, it applies to existence conditions for categories of laws that Congress has required or permitted to play a role in adjudication; and it is quite distinct from the epistemic account. The idea is that the content of some constitutional norm, from the perspective of one actor, might be different from its content viewed from another perspective. Specifically, what Article I, Section 7 means for members of Congress might be different from what it means for courts and other noncongressional actors. Arguably, (1) the Constitution tells legislators, including the Speaker of the House and Senate President, that a text must be enacted by a majority of a quorum in each house to be ripe for presidential signature and thereby statutory existence; and (2) the Constitution tells noncongressional actors that a text must be enrolled by the Speaker of the House and Senate President to be ripe for presidential signature and thereby statutory existence. To put the idea another way, the Constitution might both articulate certain existence conditions and make the determinations of certain official actors (here, the legislative officers) authoritative for all other actors (here, the courts and others) as to whether those conditions have been satisfied.

As we shall explain in a moment, the perspectival conception of constitutional norms provides an attractive interpretation of the "political question" doctrine: Genuine "political questions" are just questions of constitutional law where the norms are perspectival and, in particular, make certain nonjudicial actors authoritative visà-vis the courts. Whether perspectivalism explains EB is less clear. The issue is simply one of constitutional interpretation: Given the text, original understanding, constitutional structure, underlying purposes, and other relevant interpretive sources, is Article I, Sec-

${ }^{188}$ See supra pp. $1126-27$. 
tion 7 best interpreted to make the presiding legislative officers authoritative, for courts, as to the content of the bills that have "passed" each house? The text itself does not exude the deference of, say, Article I, Section 5, which provides: "Each House shall be the Judge of the ... Qualifications of its own Members ...."189 The Court in Powell v. McCormack agreed that this language would make Congress authoritative as to whether a member possessed the age, citizenship, and residency qualifications set forth earlier in the Constitution..$^{190}$ Nor does Article I, Section 7 seem to call for the deference entailed by Article I, Section 3, which states: "The Senate shall have the sole Power to try all Impeachments." Court in Nixon v. United States relied on that language in holding the form of the impeachment trial to be a political question. ${ }^{192}$ Indeed, the relevant text of Article I seems no more "perspectival" than the language of the Origination Clause. The former provides: "Every Bill which shall have passed the House of Representatives and the Senate, shall, before it become a Law, be presented to the President...."193 The latter states: "All Bills for raising Revenue shall originate in the House of Representatives ...." ${ }^{194}$ The assurance by the Speaker of the House and the Senate President that a law originated in the House or is not a revenue-raising measure, does not bind the courts on those issues; ${ }^{195}$ why should their assurance as to "passage" be treated differently? Perhaps one should read the Bicameralism Clause ${ }^{196}$ in conjunction with Article I, Section 5's authorization for "Each House [to] determine the Rules of its Proceedings." ${ }^{1197}$ But the seeming thrust of this last provision is to make Congress acting as a body authoritative (within limits) as to the procedural framework for legislation, not to make individual legislative officers authoritative as to the application of that framework.

\footnotetext{
${ }^{189}$ U.S. Const. art. I, $\S 5$, cl. 1.

190395 U.S. 486 (1969).

${ }^{191}$ U.S. Const. art. I, $\$ 3$, cl. 6.

${ }^{192} 506$ U.S. 224 (1993). For a discussion of the Nixon case, see infra notes 208-15 and accompanying text.

${ }^{193}$ U.S. Const. art. I, $\$ 7$, cl. 2.

${ }^{194}$ Id. art. I, $\$ 7$, cl. 1 .

${ }^{195}$ United States v. Munoz-Flores, 495 U.S. 385, 391 n.4 (1990).

${ }^{196}$ U.S. Const. art. $1, \S 7, \mathrm{cl} .2$.

${ }^{197}$ Id. art. $1, \S 5$, cl. 2.
} 
The "perspectival" reading of Article I, Section 7 would require a district court to follow EB even in cases where the court did not believe EB to be epistemically warranted-even in cases where the court believed the presiding officers to have lost their status as statutory experts. In effect, the "perspectival" reading injects some or all of the institutional considerations referenced by the Field Court (litigation costs, error costs, incentive considerations, popular uncertainty, and the like) ${ }^{198}$ into the meaning of Article I, Section 7. Those considerations, in turn, would support a rigid EB rule extending even to the (occasional) cases of impaired presiding officers. Conversely, if the Constitution's text and other interpretive sources do not support this reading, then a district court required to take account of "statutes" (and unconstrained by Supreme Court doctrine) would properly depart from EB and consult other evidence of statutory existence and content in cases where the court believed the Speaker of the House or Senate President to be epistemically impaired.

In short, our argument may well imply that EB should be limited-that the sweeping rule of Field is too broad. Indeed, if the only basis for EB is epistemic, then there does not really need to be an EB doctrine: Field should be overruled and the courts permitted to consider all relevant evidence in determining compliance with Article I, Section 7, including the (normally conclusive) evidence provided by the enrolled bill. This conclusion would hardly be a reductio of our view, however. Before Field, in Gardner v. Collector, the Court took a very different view of the admissibility of journal evidence and the like in determining statutory content:

We are of opinion ... that whenever a question arises in a court of law of the existence of a statute, or of the time when a statute took effect, or of the precise terms of a statute, the judges who are called upon to decide it, have a right to resort to any source of information which in its nature is capable of conveying to the judicial mind a clear and satisfactory answer to such question; always seeking first for that which in its nature is most appropriate, unless the positive law has enacted a different rule. ${ }^{199}$

\footnotetext{
${ }^{198}$ See supra text accompanying notes $177-79$.

${ }^{199} 73$ U.S. (6 Wall.) 499, 511 (1867).
} 
United States $v$. Ballin, a companion case to Field, affirmed EB but also cited the just-quoted language from Gardner and ultimately looked beyond the enrolled bill, to the Congressional Record, to determine the presence of a quorum in the House.$^{200}$ Much more recently, in United States v. Munoz-Flores, the Court declined to apply EB in the context of an Origination Clause challenge..$^{201}$ In effect, Munoz-Flores limits EB to the bicameralism provision, rather than other existence conditions or other constitutional norms. Some state supreme courts have gone even further-permitting courts to look to legislative journals or all relevant evidence when any questions are raised about the existence of state statutes. ${ }^{202}$

In sum, Field implicitly adopts a perspectival account of Article I, Section 7 which is difficult to square with the constitutional text and other sources of constitutional meaning. EB is nonetheless consistent with our claim that this provision states an existence condition, if EB is understood as granting merely epistemic deference. This epistemic view of EB would require that Field be modified-to make clear that EB states an evidentiary presumption, but one that is nonetheless rebuttable by certain kinds of evidence in certain circumstances.

\section{B. The Political Question Doctrine}

Why have a political question doctrine ("PQ")? What distinctive conceptual space does such a doctrine fill? There are a range of answers to these questions, two of which are quite extreme. One such extreme answer was popularized by Professor Louis Henkin: There is no political question doctrine. ${ }^{203}$ A "political question" holding is nothing other than a judicial determination, on the merits, that some choice by a nonjudicial actor is constitutionally valid or unconstrained. ${ }^{204}$ The other extreme view was popularized by Profes-

\footnotetext{
${ }^{200} 144$ U.S. 1 (1892).

${ }^{201} 495$ U.S. 385 (1990).

${ }^{202}$ See Robert F. Williams, State Constitutional Limits on Legislative Procedure: Legislative Compliance and Judicial Enforcement, 48 U. Pitt. L. Rev. 797, 816-23 (1987).

${ }^{203}$ Louis Henkin, Is There a "Political Question" Doctrine?, 85 Yale L.J. 597 (1976).

${ }^{204}$ See id. at 601-02 (arguing that in the cases in which the Court has been thought to treat some issue as a political question, it should be read as having said that " $[\mathrm{t}] \mathrm{he}$ act complained of violates no constitutional limitation ..., either because the Consti-
} 
sor Alexander Bickel and is partly reflected in the Baker v. Carr ${ }^{205}$ test: A "political question" holding is a judicial determination that prudence bars the court from reaching the merits of a constitutional challenge to a choice by a nonjudicial actor that (were the court to consider the merits) the court might properly determine to be unconstitutional. ${ }^{206}$ For Bickel and others, ${ }^{207} \mathrm{PQ}$ is an especially clear and pure example of judicial "underenforcement" of constitutional norms.

We reject both of these extreme views. Where the constitutional norms are existence conditions, the Bickelian view of $P Q$ is untenable. The Henkinian view, in contrast, is dogmatic. If the Constitution is best interpreted as (1) articulating certain norms (existence conditions or others) and (2) instructing the courts to take the determinations of certain nonjudicial actors as authoritative with respect to those norms, then a special constitutional framework for adjudication emerges which is different from the case where nonjudicial choice is unconstrained, and different again from the standard case where nonjudicial choice is constrained and nonjudicial actors lack special authority vis-à-vis courts as to the interpretation of the constraints. Nothing in the concept of a constitution, or in a general practice of judicial review, or in any standard view of constitutional interpretation (textualism, originalism, nontextualism, and so forth) precludes this special structure. Where it obtainsand only there-does a genuine political question arise.

Note that our conception of PQ involves the full enforcement of constitutional norms. Consider the Nixon case. ${ }^{208}$ Judge Nixon challenged his impeachment, claiming that it was void because his trial was conducted in front of a committee rather than the full Senate. The Court found a political question. On our view, Nixon was rightly decided as a PQ case if and only if the relevant constitu-

tution imposes no relevant limitations, or because the action is amply within the limits prescribed").

${ }^{205} 369$ U.S. 186 (1962).

${ }^{206}$ See Bickel, supra note 2, at 70-71. But see Gerald Gunther, The Subtle Vices of the "Passive Virtues"-A Comment on Principle and Expediency in Judicial Review, 64 Colum. L. Rev. 1, 24 (1964) (criticizing Bickel's approach as unprincipled).

${ }^{207}$ E.g., Sager, supra note 183, at 1224-28; Lawrence G. Sager, Justice in Plain Clothes: Reflections on the Thinness of Constitutional Law, 88 Nw. U. L. Rev. 410 , 429 n.20 (1993).

${ }^{208}$ Nixon, 506 U.S. at 224. 
tional provisions, particularly Article I, Section 3, Clause 6 ("The Senate shall have the sole Power to try all Impeachments" ${ }^{209}$ ), both constrain (or at least might constrain) the process by which the Senate issues a judgment of impeachment and make the Senate authoritative as to the content of these constraints. If that is indeed the correct reading of the Impeachment Clause, then the Nixon Court fully enforced it. Thus read, the Clause addresses to the courts a genuine existence condition for a judgment of impeachment, one that has the interesting form of making reference to the determinations of some other body (in this case the Senate). Only if the Senate has purported to impeach some official and (at least implicitly) to find compliance with the "trial" requirement in Article I, Section 3, Clause 6 has the official really been impeached from a judicial perspective. The Court was fully sensitive to its beliefs about this "perspectival" condition: Had it believed that the "Senate" impeaching Nixon was an anti-Nixon cabal rather than the grouping of real Senators comprising the real Senate, or that the Senate document removing Nixon from office did not use the words impeachment at all and was an ordinary Senate resolution, or that this document did not purport to have been enacted by twothirds of a Senate quorum, it would not have found a political question. ${ }^{210}$

Our view of PQ is nicely articulated by Justice White in his Nixon concurrence:

${ }^{209}$ U.S. Const. art. I, § 3, cl. 6.

${ }^{210}$ In addition, Justices White and Souter would not have found a political question if the Senate procedure was so arbitrary as not to fall within any reasonable understanding of the word "try." See Nixon, 506 U.S. at 250 (White, J., concurring) (indicating that the Senate was obliged to follow "a set of minimal procedures"); id. at 253 (Souter, J., concurring) (arguing that "more searching review of impeachment proceedings" would be warranted "[i]f the Senate were to act in a manner seriously threatening the integrity of its results, convicting, say, upon a coin toss"). Although Justice Souter invoked Bickel for his view, id. (Souter, J., concurring), we find nothing in the White or Souter position inconsistent with our perspectival account of PQ. Just as the Court must satisfy itself that the body purporting to impeach a judge is, in fact, the Senate before accepting that body's impeachment determination, so the Court might need to first satisfy itself that the Senate procedures are not so arbitrary as to fall outside the range of arguable "trials" before accepting both the Senate's choice of procedures within that range and the outcome of those procedures. The "trial" condition would then function as a political question with respect to congressional determinations within that range. 
[T]he issue in the political question doctrine is not whether the constitutional text commits exclusive responsibility for a particular governmental function to one of the political branches. There are numerous instances of this sort of textual commitment, e.g., Art. I, $\S 8$, and it is not thought that disputes implicating these provisions are nonjusticiable. Rather, the issue is whether the Constitution has given one of the political branches final responsibility for interpreting the scope and nature of such a power. ${ }^{211}$

This view is also reflected in the first of Baker's multiple factors: "a textually demonstrable constitutional commitment of the issue to a coordinate political department." 212 We would modify this description somewhat by dropping the adverb "textually": Our view of PQ does not entail an interpretive view that gives high priority to the text. For example, a structuralist, intentionalist, or moralist about interpretation could conclude that the Constitution on some issue is best understood to make certain nonjudicial determinations binding on the courts.

Ironically, the full Baker test, which contemplates PQ rulings on various grounds that have only a tenuous link to the content of constitutional law, better fits with the pre-Baker case law than with the Court's subsequent PQ decisions. An extravagant PQ decision like Pacific States Telephone \& Telegraph Co. v. Oregon, which held equal-protection and due-process (not just Guaranty Clause) challenges to the form of state government to be nonjusticiable, ${ }^{213}$ is much more in keeping with the prudentialist spirit of Baker's secondary factors than the Court's nearly perfect record of denying PQ claims in the forty years since Baker. In only two cases during this period-Nixon and Gilligan v. Morgan ${ }^{214}$-has the Court found a PQ, and in both cases the straight constitutional argument for deference that we have sketched seems quite plausible.

\footnotetext{
${ }^{211}$ Id. at 240 (White, J., concurring).

${ }^{212}$ Baker, 369 U.S. at 217. Justice Brennan observed in Baker, "Deciding whether a matter has in any measure been committed by the Constitution to another branch of government . . . is itself a delicate exercise in constitutional interpretation, and is a responsibility of this Court as ultimate interpreter of the Constitution." Id. at 211; see also Powell, 395 U.S. at 518-48 (examining Article I, $\$ 5$ for a textual commitment to a coordinate political branch). Also note that the Court in Nixon, 506 U.S. at 228 , emphasizes the first two Baker factors.

${ }^{213} 223$ U.S. 118 (1912).

${ }^{214} 413$ U.S. 1 (1973).
} 
The same argument also seems strong in some of the most famous pre-Baker cases, such as Luther v. Borden and Coleman v. Miller. ${ }^{215}$

Is the difference between our view of $P Q$ and Bickel's-between the full enforcement and underenforcement accounts-more than semantic? We think so, for reasons already suggested. The Bickelian account allows "institutional" or other prudential considerations to prompt a court to rule against some constitutional claimant even if the considerations do not figure in the best interpretation of the constitutional provision raised; our account does not, at least where the provision is an existence condition. ${ }^{216}$

Again imagine a district court instructed by Congress to adjudicate claims arising under federal statutes. Smith sues under the "Safe Workplaces Act." Assume now that the Act did pass Congress and receive the President's signature as a result of widespread outrage over a series of grisly workplace accidents. Acme concedes that the Act satisfies bicameralism and presentment, but argues that it is no law because it exceeds the Commerce Clause (the act applies to all workplaces, say). Smith replies that Acme's defense constitutes a political question because of various "institutional" considerations: (1) invalidating the act would weaken the court's legitimacy; ${ }^{217}$ (2) invalidation would be undemocratic; ${ }^{218}$ and (3) a systematic judicial practice of second-guessing Congress on Commerce Clause issues would be expensive and on balance unjustified, given that the federal structure of Congress ensures that nearly all statutes fall within the Clause. The Bickelian would allow the first two

\footnotetext{
${ }^{215} 307$ U.S. 433 (1939).

${ }^{216}$ Cf. Rachel E. Barkow, More Supreme than Court? The Fall of the Political Question Doctrine and the Rise of Judicial Supremacy, 102 Colum. L. Rev. 237, 244-73 (2002) (distinguishing between classical and prudential views of the political question doctrine).

${ }^{217}$ Cf. Planned Parenthood v. Casey, 505 U.S. 833, 865 (1992) (reaffirming the central holding of Roe v. Wade, 410 U.S. 113 (1979), and arguing that to do otherwise "would seriously weaken the Court's capacity to exercise the judicial power and to function as the Supreme Court of a Nation dedicated to the rule of law").

${ }^{218}$ For a discussion of democratic values as a type of "institutional" consideration arguably warranting underenforcement, see Adler, Judicial Restraint, supra note 45, at 785-806.
} 
considerations, and perhaps the third, ${ }^{219}$ to influence the court's ruling on Acme's defense.

On the one hand, if Article I, Section 8 is an application condition, and if courts have broad powers to determine the reviewability of various sorts of claims (including constitutional claims), ${ }^{220}$ then we would also countenance a judicial ruling against Acme based on the various "institutional" considerations just described. On the other hand, if the Commerce Clause sets forth an existence condition for federal statutes and other federal law-as we believe it does-then these considerations legitimately bear on the court's decision only if they relate to the merits of Acme's defense-only if they figure in the best interpretation of Article I, Section 8. This is plausible only on an interpretive theory that gives substantial weight to nontextual sources. Consider these possible readings of the Commerce Clause:

(Nonperspectival): Congress may regulate any activities that are literally interstate or that are closely linked to interstate activities, for instance, by falling in the stream of commerce.

(Nonperspectival): Congress inay regulate any activities where regulation is justified by federalism failures.

(Perspectival): A law satisfies the Commerce Clause, from Congress's perspective, if it is justified by federalism failures. A law satisfies the Commerce Clause, from the Court's perspective, if Congress had a rational basis for finding a federalism failure.

The systematic costs and benefits of judicial inquiry into federalism failures, as well as perhaps legitimacy and democratic costs, might warrant the third, perspectival interpretation of the Commerce Clause-despite the lack of direct textual grounding for that reading-on an appropriate interpretive theory. Perhaps the Framers, motivated by institutional considerations, intended Congress's Article I, Section 8 determinations to be authoritative for the courts.

${ }^{219}$ We say the Bickelian would only possibly allow the third consideration because it is systematic rather than case-specific, as most of Bickel's own examples were. See Bickel, supra note 2, at 183-98.

${ }^{220}$ Cf. Webster v. Doe, 486 U.S. 592, 607-09 (1988) (Scalia, J., dissenting) (discussing various judicially created doctrines giving rise to nonjusticiability). 
Or perhaps those considerations are interpretive considerations just by virtue of their moral weight and the presence of some indeterminacy in the language of the Clause. In any event, the judge ought not take account of these factors if she views them as merely prudential. Judicial power to determine reviewability is no longer in play, because the constitutional issue here is inseparable from the merits of a nonstatutory claim that the judge must (by assumption) review-the plaintiff's claim under a statute whose existence he asserts and the defendant denies. The systematic-cost, democracy, and legitimacy factors must, in the judge's view, have an "internal" role in fleshing out the meaning of the Commerce Clause, and once she takes them as having that role, she no longer sees herself as underenforcing the Clause.

Note finally that (1) any interpretive theory which internalizes a wide range of institutional factors and/or produces a large set of perspectival norms will be highly controversial, and (2) although a view of adjudication that gives federal courts broad powers to determine reviewability will also be controversial, the controversy will be quite different. One might be a nontextualist about constitutional interpretation yet believe that courts are obliged to adjudicate all constitutional claims or, conversely (like Justice Scalia in Webster v. Do ${ }^{221}$ ), a textualist who sees courts as having a common law power to determine reviewability (even of constitutional claims) absent an explicit statutory constraint. ${ }^{222}$

In any event, $P Q$, like $E B$, is consistent with our claim that existence conditions are fully enforced. While EB is best seen as an existence condition whose enforcement warrants epistemic deference by courts to nonjudicial actors, $\mathrm{PQ}$ is best understood as turning on the perspectival nature of certain constitutional commands. We also think that our account of PQ does a generally better job of explaining the modern cases than the leading alternatives. Finally, our view of $\mathrm{PQ}$ is genuinely distinct from the underenforcement view: on our view, the various costs of constitutional litigation legitimately trigger the political question doctrine, with respect to a constitutional provision stating an existence condition only if those

${ }^{221}$ Id. (Scalia, J., dissenting).

${ }^{222}$ See id. at 608-09 (Scalia, J., dissenting). 
costs have an "internal" role in determining the correct interpretation of that provision.

\section{Rational Basis Review}

Professor Lawrence Sager, in his seminal article on the underenforcement of constitutional norms, suggests that the rational basis strand of equal protection and substantive due process, as well as the Takings Clause and the Privileges or Immunities Clause, are "likely candidates" for characterization as underenforced. ${ }^{223}$ Professor Paul Brest, in an equally famous early piece, proposes that description for the rational basis doctrines, unconstitutional motive doctrines, and the dormant commerce clause. ${ }^{224}$

Our general strategy for defusing these putative examples of underenforcement or nonenforcement should already be clear: Unless a certain contentious view of the Court's power to adopt doctrines deviating from its best reading of the Constitution is held, these doctrines are perhaps partly justifiable on epistemic grounds, but otherwise only if they mirror the content of the underlying constitutional provisions (content that might be "perspectival" in structure). Rather than belabor the point, we focus here on the rational basis doctrines.

Consider first the equal protection guaranty. A law that does not discriminate against a suspect class or otherwise trigger heightened scrutiny satisfies equal protection if it "rationally furthers a legitimate state purpose or interest."225 Is the equal protection component of the Fifth Amendment an existence condition for federal law? And is the Equal Protection Clause ${ }^{226}$ itself an existence condition for state law? We answer both questions in the affirmative, for reasons elaborated in Part II. Thus, equal protection cannotpace Sager, Brest and others-be underenforced. Indeed, a moment's reflection on the rational basis test makes the underenforcement claim quite puzzling. What is the constitutional norm such that (1) a law lacking a rational relation to a legitimate gov-

\footnotetext{
${ }^{223}$ Sager, supra note 183 , at $1219-20$.

${ }^{224}$ Brest, supra note 183 , at $588-601$.

${ }^{225}$ See, e.g., San Antonio Indep. Sch. Dist. v. Rodriguez, 411 U.S. 1, 55 (1973) (citing McGinnis v. Royster, 410 U.S. 263, 270 (1973)).

${ }^{226}$ U.S. Const. amend. XIV, $\S 1$.
} 
ernmental end represents a clear or central violation of that norm, but (2) other laws, albeit rationally supportable, also violate the norm? Is it the norm of justifiability, or instrumental (means-end) justifiability? Can it really be said that any law that is not instrumentally justifiable - that does not really advance some non-trivial, appropriately public goal-violates the Constitution's equality guaranty? This is an implausibly broad reading of equality in the substantive sense-what Professor Dworkin calls "equal treatment"- and has no immediately apparent connection to equality in the procedural or expressive sense, "equal respect and concern."라

Constitutional equal treatment, broadly read, mandates equal welfare (or equal resources), modulo considerations of individual responsibility. ${ }^{228}$ Constitutional equal treatment, more narrowly read, is an anticaste principle-a principle proscribing laws that produce or maintain the subordination of socially salient groups. ${ }^{229}$ Both norms are plausibly "perspectival," at least in part. Given the difficulty in determining what promotes long-term equality of resources or welfare, or what effectively undermines rather than entrenches a system of racial or gender castes, perhaps legislative determinations on these matters (within some range) should be binding on the courts. ${ }^{230}$ But it is hard to see why the rational basis test should serve to delimit that range. Irrational laws that redistribute wealth, welfare, or status from an arbitrary subset of the wealthy to an arbitrary subset of the poor or middle-class, or from an arbitrary subset of the higher castes to an arbitrary subset of the lower castes, serve to advance substantive equality (albeit in a haphazard way). So on the substantive views of equality just mentioned, broader or narrower, the "rational basis" component of equal protection is a legal fiction. On these views, courts should not

${ }^{227}$ Dworkin, Taking Rights Seriously, supra note 49, at 227 (discussing the "equal treatment" versus "equal respect and concern" construals of equality).

${ }^{228}$ See, e.g., G.A. Cohen, Equality of What? On Welfare, Goods, and Capabilities, in The Quality of Life 9, 9-10 (Martha Nussbaum \& Amartya Sen eds., 1993) (discussing equal welfare as a social ideal).

${ }^{229}$ See, e.g., Cass R. Sunstein, The Anticaste Principle, 92 Mich. L. Rev. 2410, 241113 (1994).

${ }^{230}$ Cass R. Sunstein, The Partial Constitution 137-41 (1993); Adler, Judicial Restraint, supra note 45 , at 888 ("But even those scholars who advocate welfare rights most strongly seem to doubt whether such rights should be fully justiciable."). 
strike down merely irrational laws (and indeed almost never do so) because such laws, without more, are fully consistent with the constitutional equality guaranty

If equality is understood "expressively," then once more the rational basis test is a legal fiction, a polite but misleading way of producing judicial denials of constitutional claims in an area where truly there is no constitutional constraint at all. On the expressive view, a law that "expresses" the inferiority of some groupexpresses in the strict linguistic sense or in the broader "social meaning" sense-is unconstitutional. ${ }^{231}$ Presumably, courts should fully enforce this norm. Even if they should not, it is difficult to see how the rational basis test "underenforces" a constraint on inappropriate meanings. Irrationality (without more) merely "expresses" interest-group politics, garden variety public-choice pathologies, not reprehensible claims about the inferiority of women, blacks, gays, or other historically oppressed groups. ${ }^{232}$

${ }^{231}$ See Matthew D. Adler, Expressive Theories of Law: A Skeptical Overview, 148 U. Pa. L. Rev. 1363, 1370-71 (2000) (describing the expressivist view of equal protection).

${ }^{232}$ The disconnect between irrationality as such and reprehensible animosity can be seen in the Court's cases that nominally fail to apply heightened scrutiny but nevertheless invalidate laws based on prejudice or hatred. See Romer v. Evans, 517 U.S. 620,632 (1996) (invalidating a Colorado constitutional amendment that could only be explained by animus toward homosexuals); City of Cleburne v. Cleburne Living Ctr., Inc., 473 U.S. 432, 450 (1985) (holding that a permit requirement for a group home was invalid because it "appear[ed] to [the Court] to rest on an irrational prejudice against the mentally retarded"); U.S. Dep't of Agric. v. Moreno, 413 U.S. 528, 534 (1973) (striking down a food stamp eligibility provision because "a bare congressional desire to harm [hippies] cannot constitute a legitimate governmental interest"). Justice O'Connor recently characterized these cases as standing for the proposition that "[w]hen a law exhibits ... a desire to harm a politically unpopular group, [the Court] applie[s] a more searching form of rational basis review." Lawrence v. Texas, $123 \mathrm{~S}$. Ct. 2472, 2485 (2003) (O'Connor, J., concurring). We do not take a view as to whether the cases sustaining equal protection challenges without formally applying heightened scrutiny are best characterized as employing such covert heightened scrutiny rather than a freestanding principle barring government action rooted in hatred. See Ashutosh Bhagwat, Purpose Scrutiny in Constitutional Analysis, 85 Cal. L. Rev. 297, 357 (1997) (describing the "strong anti-caste principle recognized in Moreno, Cleburne, and Romer"); cf. Vill. of Willowbrook v. Olech, 528 U.S. 562, 564-65 (2000) (holding that allegation of arbitrary or irrational discrimination against a "class of one" states a rational basis claim under the Equal Protection Clause without deciding whether proof of "subjective ill will" by the government decisionmaker would be necessary for plaintiff to prevail). We simply note that in the cases finding equal protection violations without nominally applying heightened scrutiny, the constitutional flaw 
Finally, proceduralists view equality as constraining the motivations of legislators or other governmental actors. For example, Professor Cass Sunstein suggests that legislators must be appropriately public-regarding, ${ }^{233}$ while Professor John Hart Ely suggests that they must not be motivated by racial animus or other sorts of prejudice..$^{234}$ Narrower conceptions of the illegal motivation (like Professor Ely's) call into question the rational basis test. How does irrationality, as such, evidence racial prejudice? Broader conceptions of the illegal motivation (like Professor Sunstein's) are only tenuously linked to the concept of equality.

Perhaps one can draw a link instead to due process: Fifth Amendment equality is strictly a matter of due process, and Fourteenth Amendment equality is at least textually proximate to due process. Further, an objectively irrational law does evidence subjectively arbitrary motivations. The interesting question for the Sunsteinian is why direct judicial inquiry into legislative motiva$\operatorname{tion}^{235}$ (where the claim is simply lack of public-spiritedness, not racial animus) should be precluded. One answer is as follows: The systematic costs of allowing such an inquiry would be quite high, and in most cases objective irrationality tracks subjective arbitrariness. This argument is persuasive, for us, only if litigation costs are relevant to the meaning of the equal protection guaranty-only if the guaranty is interpreted in "perspectival" fashion in the following manner: (1) The equal protection guaranty, for legislators, means that they ought to consider only sufficiently public considerations in deliberating about proposed laws, and (2) because it is costless for legislators to police their own motivations, but costly for courts to do so, the constitutional value of ensuring publicspiritedness, for courts, translates into an objective rational basis

identified by the Court is not a failure of instrumental justifiability as required by the conventional formulation of the rational basis test.

${ }^{233}$ Cass R. Sunstein, Naked Preferences and the Constitution, 84 Colum. L. Rev. 1689,1689 (1984) (describing naked preferences violative of equal protection and other doctrines as "the distribution of resources or opportunities to one group rather than another solely on the ground that those favored have exercised the raw political power to obtain what they want").

${ }^{234}$ See John Hart Ely, Democracy and Distrust: A Theory of Judicial Review 137 (1980).

${ }^{235}$ Cf. Citizens to Pres. Overton Park, Inc. v. Volpe, 401 U.S. 402 (1971) (contemplating judicial inquiry into agency official's subjective reasons for challenged decision). 
test. On this view, rational basis review is not a legal fiction, but the full content of a real constitutional constraint addressed to courts. Note, however, that if the constitutional term "equal protection" means procedural equality-not procedural equality as tempered by cost considerations-then this procedural, perspectival defense of the rational basis test must fail.

To sum up, the equal protection rational basis test would be a real case of underenforcement if the Equal Protection Clause required statutes to be means-end justifiable in light of a broad (but not universal) category of public ends and if the test were a device for invalidating the clearest cases of means-ends failure. Because the equal protection guaranty operates in many contexts as an existence condition, and because the guaranty in any event does not readily map onto instrumental justifiability-but instead onto equal treatment or equal concern and respect-the better view is either that the test demarcates an area free of constitutional constraint or that it represents a constitutional mandate that the judicially cognizable evidence for motivational failures violating procedural equality be objective rather than subjective.

Perhaps shifting from equal protection to substantive due process offers new ways to conceptualize the rational basis test. Generic justifiability seems more relevant to substantive due process than to equality. Consider that the liberties triggering due process scrutiny are not absolute, but rather defeasible by sufficiently weighty countervailing goals. Imagine, in other words, that the real content of substantive due process is to invalidate a law (or the application of a law) that infringes protected liberties, unless the infringement is closely tailored to an important governmental interest. ${ }^{236}$ In those circumstances in which the substantive due process norm functions as an application condition rather than an existence condition-as it might function if focused on the justifiability of applications of challenged laws, not on the laws' overall scope-the rational basis component of substantive due process could be an example of genuine underenforcement. The state sanctions $P$ 's protected lib-

${ }^{236}$ Washington v. Glucksberg, 521 U.S. 702, 721 (1997) ("[T]he Fourteenth Amendment "forbids the government to infringe ... "fundamental" liberty interests at all, no matter what process is provided, unless the infringement is narrowly tailored to serve a compelling state interest." (quoting Reno v. Flores, 507 U.S. 292, 302 (1993))); United States v. Salerno, 481 U.S. 739, 748-49 (1987). 
erty; $P$ defends on due process grounds; $P$ 's sanction is truly unconstitutional if not tailored to an important interest; a court (recognizing the institutional and legitimacy costs of more intrusive review) strikes down the sanction only if patently irrational.

A reformulated version of this story might be offered for the case of existence conditions. Suppose that a law infringing (some or many) instances of a protected liberty is void-no law at all-if not closely related to an important governmental interest. The litigation costs, error costs, and uncertainty costs of full judicial application of this existence condition would be high. Arguably, the public interest in minimizing such costs is itself an important goal that would come into play under the Due Process Clause to limit the scope of judicially cognizable violations. A law infringing a protected liberty is not, all things considered, unconstitutional from a judicial point of view unless the systemic costs of a judicial practice of reviewing laws of this type are sufficiently low (in other words, unless the law is patently irrational).

The interpretive puzzle here is to explain why this would be the best reading of due process for some but not all protected liberties-for economic liberties but not privacy. Is it not more straightforward to say that economic liberties are just not constitutionally protected? ${ }^{237}$ On that account of substantive due process, as with the substantive and expressive construals of equal protection, the rational basis test represents neither real underenforcement nor a constitutionally mandated deference to the legislative branches (à la our construal of the "political question" doctrine), but rather mere judicial verbiage marking a constitutional vacuum.

\section{The Court as Constitutional Legislator}

Throughout the preceding Sections, we have placed to one side the possibility of viewing the Court as a constitutional legislatorempowered, to some extent, to issue general doctrinal rules that bind lower courts and that do not perfectly match underlying norms. If the Court does not have this power, then "institutional" considerations legitimately influence adjudication of constitutional

${ }^{237}$ See Ferguson v. Skrupa, 372 U.S. 726, 730 (1963) ("We have returned to the original constitutional proposition that courts do not substitute their social and economic beliefs for the judgment of legislative bodies, who are elected to pass laws."). 
existence norms only if these considerations (partly) determine the content of those norms. For many norms, demonstrating that institutional concerns play this internal role will mean adopting a problematic, or at least controversial (qua nontextual) view of constitutional interpretation. But if the Court is a constitutional legislator, then by hypothesis certain factors-perhaps including litigation costs, judicial legitimacy, error rates, and the like-can drive a wedge between constitutional norms and constitutional doctrines. ${ }^{238}$

To be sure, this strategy for incorporating "institutional" factors within doctrine trades controversy about interpretive methodology for a highly controversial view of the Court's role. Note that the view being mooted here is not entailed by judicial supremacy. The judicial supremacist insists that Supreme Court doctrine is binding on all other actors, lower courts as well as nonjudicial actors. ${ }^{239}$ But the supremacist might also insist that the Court is most fundamentally an adjudicative body that must focus on the case at hand, and issue holdings that represent (the Court's best reading of) applicable constitutional norms. What is on the table, in short, is a radical variant of judicial supremacy-one that subordinates the Court's adjudicative role to its function as the enactor of rules guiding the lower courts. On this view, just as ordinary laws are legitimately overinclusive and underinclusive with respect to the substantive goals animating them, so, too, constitutional doctrine is legitimately overinclusive and underinclusive with respect to constitutional norms.

\footnotetext{
${ }^{238}$ See Schauer, supra note 17 (discussing how rules are inevitably both under- and overinclusive relative to underlying justifications).

${ }^{239}$ See Cooper v. Aaron, 358 U.S. 1, 18 (1958) ("[T]he federal judiciary is supreme in the exposition of the law of the Constitution, and th[is] principle has ... been respected [since Marbury] by this Court and the Country as a permanent and indispensable feature of our constitutional system."); Larry Alexander \& Frederick Schauer, Defending Judicial Supremacy: A Reply, 17 Const. Comment. 455 (2000); Larry Alexander \& Frederick Schauer, On Extrajudicial Constitutional Interpretation, 110 Harv. L. Rev. 1359 (1997). For different views, see, for example, Robert A. Burt, The Constitution in Conflict 353-75 (1992); Frank H. Easterbrook, Presidential Review, 40 Case W. Res. L. Rev. 905 (1990); Larry D. Kramer, The Supreme Court, 2000 Term-Foreword: We the Court, 115 Harv. L. Rev. 4 (2001); Edwin Meese I1I, The Law of the Constitution, 61 Tul. L. Rev. 979 (1987); Walter F. Murphy, Who Shall Interpret? The Quest for the Ultimate Constitutional Interpreter, 48 Rev. Pol. 401 (1986); Michael Stokes Paulsen, The Most Dangerous Branch: Executive Power to Say What the Law Is, 83 Geo. L.J. 217 (1994).
} 
Crucial to the elaboration of this view will be some limitation on the range of factors that legitimately prompt the Court to adopt overinclusive or underinclusive doctrines. Consider once again the enrolled bill doctrine ("EB") and Field. The Court in Field seemingly viewed itself as constitutional legislator and believed all of the following: (1) a text must be approved by a majority of (a quorum of) each house to satisfy the bicameralism norm set forth in Article I, Section 7; (2) the net costs of instructing the lower courts to apply the bicameralism norm directly would be quite high, as compared to instructing the lower courts to follow $\mathrm{EB} ;{ }^{240}$ and therefore (3) constitutional doctrine should mandate EB as the test for bicameralism. The trick here is explaining which factors legitimately enter the cost-benefit calculus performed at step (2).

Surely this calculus cannot be a straight moral balancing. If it were, the Court could adopt any doctrine it took to be morally justified on balance. Imagine, for example, the Court choosing between three options: directly incorporating the bicameralism norm into doctrine, adopting EB instead, or adopting a rule that statutes must satisfy EB and must be accompanied by a "statutory impact analysis" (vetted by the Congressional Budget Office) showing the statute to have net benefits. ${ }^{241}$ If all morally relevant considerations legitimately enter into the Court's formulation of constitutional doctrine, then the Court-believing this final doctrinal option to be best supported by welfarist considerations, and not undermined by others-would be legally warranted in adopting it.

In short, the constitutional-legislator view presupposes that there are a range of constitutional "values"-not identical to the full panoply of moral factors-that the Court should consider in crafting doctrinal rules. ${ }^{242}$ Evaluating this view is a large task, one we do

\footnotetext{
${ }^{240}$ Marshall Field \& Co. v. Clark, 143 U.S. 649, 673 (1892) ("The evils [of EB] would be far less than those that would certainly result from [permitting lower courts to look to journals].").

${ }^{241}$ Cf. Exec. Order No. 12,866, 3 C.F.R. 638 (1993) (requiring that executive agencies' rules satisfy a cost-benefit test where statutorily permissible, and that agencies prepare formal cost-benefit analyses of economically significant rules for review by the Office of Management and Budget), amended by Exec. Order No. 13,258, 3 C.F.R. 204 (2002).

${ }^{242}$ Consider one such value: The Constitution should not be interpreted to bring upon a catastrophe. That value may well have been at work in the Canadian Supreme Court's decision in In re a Reference by the Governor in Council concerning certain language rights under Section 23 of the Manitoba Act, 1870, and Section 133 of the
} 
not attempt to pursue here. On the one hand, the view remains strikingly at odds with received understandings of the Court. On the other hand, the view may fit better with actual practice than traditional accounts-given the abundance of formulaic, doctrinal tests announced by the Court that seem to track the content of the norms they purport to "interpret" quite imperfectly. ${ }^{243}$ Even on this revisionist view, however, "institutional" considerations justify the adoption of overinclusive or underinclusive doctrines only if these considerations themselves have some sort of constitutional status. That is what we have tried to show by arguing that-whatever the legitimate process of doctrinal elaboration by the Supreme Court-that process is not the same as an open-ended moral balancing.

Consider once more the Field Court's choice between announcing the bicameralism norm as doctrine (thus enabling lower courts to look outside the enrolled bill for evidence of what Congress really passed) and EB. One factor seemingly weighing in favor of $\mathrm{EB}$ is the cost of litigation. A world with the bicameralism norm as

Constitution Act, 1867, [1985] S.C.R. 721. A provision of the Canadian Constitution Act required provincial legislation to be enacted and published in both English and French, but Manitoba's laws were in English alone. The Canadian Supreme Court might have treated the constitutional requirement of bilingualism as an application condition-a guaranty of fair notice to both Francophone and Anglophone citizens. Had the court so treated the provision, it could have chosen not to enforce it. Instead, the court appeared to treat the requirement as an existence condition, see id. at 740 (rejecting, for purposes of constitutional interpretation, any "distinction between statutory provisions that are mandatory in the sense that failure to comply with them will lead to invalidity of the act in question, and directory, in the sense that failure to comply will not necessarily lead to such invalidity"). The court nevertheless "underenforced" the apparent existence condition by leaving Manitoba's existing laws in place for such time as reasonably necessary for them to be translated, re-enacted, printed, and published. See id. at 766-67. Although the case arose in the context of a suit to invalidate all of Manitoba's laws, we can imagine that the issue might have been raised as a defense in ordinary litigation. If so, would our view that existence conditions are necessarily enforced have required the Canadian courts to treat Manitoba law as void? We think not-on the assumption that the Canadian Supreme Court functions as a constitutional legislator. Exercising that function, the court might well have added to the bilingual enactment and promulgation requirements a caveat that the provision would not apply retrospectively to cause a catastrophe. Indeed, that appears to be exactly what the court, in effect, did. We are grateful to Les Green and Jeremy Webber for urging us to consider this case.

${ }^{24,3}$ See Richard H. Fallon, Jr., The Supreme Court, 1996 Term-Foreword: Implementing the Constitution, 111 Harv. L. Rev. 54 (1997); Robert F. Nagel, The Formulaic Constitution, 84 Mich. L. Rev. 165 (1985). 
doctrine has higher litigation costs than a world with EB. But does this amount to a constitutional factor properly influencing the Court's comparison of the two outcomes? And what about popular uncertainty costs or the costs expended by legislators fabricating and resisting fabrication of the Congressional Record? How are these different from straight welfare considerations, which (as we have argued) cannot, without more, shape the Supreme Court's choice between EB and the alternatives? We do not raise these issues to gainsay the powerful moral reasons in favor of EB and similar bright-line doctrines but to question whether-even on the view of the Court as constitutional legislator-many of these factors ought to affect the content of constitutional doctrine.

\section{E. Congressional Control}

On the standard reading of Article III, Congress can limit federal court jurisdiction, at least with respect to nonconstitutional law. On the standard reading of Article I, Congress can provide for novel types of federal law-for example, administrative rules-if nondelegation, separation-of-powers, and enumerated-powers constraints are satisfied. These powers, together, imply that Congress has some power to limit judicial "enforcement" of constitutional existence conditions. Imagine that Congress instructs the courts to hear claims and defenses arising under laws of type $A$, where the existence conditions for $A$-type laws are $\left\{E_{1}, E_{2}, \ldots E_{n}\right\}$, and that Congress orders courts to refrain from "enforcing" existence condition $E_{n}$. Can Congress do this? First, Congress is empowered to preclude the federal courts from hearing $A$-type claims or defenses. Second, depending on the content of $\left\{E_{1} \ldots E_{n-1}\right\}$, Congress might well be empowered to create a novel type of federal law-call it $B$ type law-for which these are the complete existence conditions. If so, then Congress's instruction that courts not enforce one condition for $A$-type law is equivalent to a legitimate instruction that courts not hear $A$-type claims or defenses and that they hear $B$ type claims and defenses.

An example may be helpful: Congress could mandate that courts apply EB in cases where it also ensured that enrolled bills met the constitutional existence conditions for valid substatutory law. The following provision might be inserted into the Judiciary Act: 
The federal courts shall hear claims and defenses arising under an enrolled bill signed by the President, without reference to extrinsic evidence that the bill may not have passed both houses in compliance with the Bicameralism Clause, if the President has determined that the bill is necessary in the interests of workplace safety.

This justiciability provision is roughly equivalent to a statute empowering the President to issue workplace safety rules:

\section{Presidential Safety Rules}

(1) The Speaker of the House and the Senate President, if they agree on a proposed workplace safety rule, shall forward the proposal to the President.

(2) The President may approve the proposal, if he determines that is necessary in the interests of workplace safety.

(3) The federal district courts shall have jurisdiction to hear claims and defenses arising under workplace safety rules.

Such workplace safety rules do not satisfy the Article I, Section 7 existence condition for statutes, but they do satisfy all conditions for administrative rules: The nondelegation condition (the "workplace-safety" goal in the Act provides an "intelligible principle" sufficient to satisfy Article I, Section 1), separation-of-powers constraints (the role of the Speaker of the House and Senate President is sufficiently preliminary to satisfy Chadha and similar $\operatorname{cases}^{245}$ ), and others (particular rules failing to satisfy enumerated powers and Bill of Rights conditions will be voided by the courts).

Crucial to this example is that the existence condition Congress has rendered nonjusticiable-the Bicameralism Clause-is not an existence condition for all federal law. If Congress, instead, had instructed the courts to hear claims and defenses arising under work-

${ }^{244}$ See Whitman v. Am. Trucking Ass'ns, 531 U.S. 457, $472-76$ (2001); A.L.A. Schechter Poultry Corp. v. United States, 295 U.S. 495, 529-42 (1935); Pan. Ref. Co. v. Ryan, 293 U.S. 388, 414-20 (1935); J.W. Hampton, Jr., \& Co. v. United States, 276 U.S. 394, 409 (1928).

${ }^{24.5}$ See Bowsher v. Synar, 478 U.S. 714 (1986); INS v. Chadha, 462 U.S. 919 (1983); Buckley v. Valeo, 424 U.S. 1 (1976). 
place safety rules without reference to whether the rules had any connection to interstate commerce, that would have been unconstitutional. Note that Article I, Section 8 is an existence condition (unwaivable by Congress) for all federal law, or at least all federal positive law; that nonjudicial federal actors cannot create state law; and that therefore courts must treat purported federal administrative rules, purported presidential orders, or other purported federal positive law that exceeds the bounds of Article I, Section 8 (and all other sources of congressional authority, such as Section 5 of the Fourteenth Amendment) as no law, notwithstanding a congressional mandate to the contrary.

Our view, in short, is that Congress possesses the power to specify the types of nonconstitutional law adjudicated by federal courts, but lacks any additional power to waive judicial enforcement of existence conditions. Where the putative "waiver" is equivalent to an instruction changing the types of nonconstitutional law the courts are authorized to adjudicate, Congress has acted permissibly given its Article III power to limit federal court jurisdiction. By contrast, a true congressional waiver would require courts to recognize some proposition as law even though that proposition does not satisfy the constitutional existence conditions for any kind of law. Congress cannot require or authorize the courts to do that.

Intuitions about particular cases provide one reason for believing that Congress lacks a general power to waive judicial enforcement of existence conditions. Imagine that Congress, in response to Chadha, tries to resuscitate the two-house legislative veto by waiving judicial enforcement of the constitutional presentment requirement with respect to a particular category of concurrent congressional resolutions. Intuitively, it seems that Congress cannot circumvent Chadha in this way. The same would hold true for a parallel waiver of judicial enforcement of bicameralism in response to Clinton v. New York-which demonstrates that the impermissibility of congressional waiver of existence conditions is not limited to cases of congressional aggrandizement.

A deeper argument is that a genuine congressional power to waive judicial enforcement of constitutional existence conditions is in tension with the fact that these conditions are addressed to 
judges $^{246}$ as well as other actors. The Constitution specifies, for judges and others, part of what it takes for a proposition to be a given type of federal or state law. If that were not the case-if existence conditions for judicial purposes were wholly extraconstitutional-then courts would never look to the Constitution in determining what law is, even to the extent of distinguishing between real governmental officials and impostors, or between real statutes and extralegislative scribblings. A legal regime in which a constitution exists and states existence conditions, yet addresses these conditions solely to nonjudicial actors, is a conceivable regime-but it is not the American regime. To be sure, as we have repeatedly acknowledged, existence conditions under the Constitution are sometimes perspectival. The Constitution might be read as instructing courts that a proposition is an $A$-type law if it satisfies conditions $\left\{E_{l}, \ldots E_{n}\right\}$, where in turn $E_{l}$ makes reference to congressional de-

\footnotetext{
${ }^{246}$ Here it is worth recalling that even the champions of robust congressional power to restrict the jurisdiction of the federal courts do not say that Congress can make itself the final arbiter of any constitutional question that would otherwise arise in the course of litigation. Thus, Professor Henry Hart's famous dialogue concludes that, even if Congress can strip the federal courts of the power to adjudicate an otherwise justiciable federal constitutional issue, state courts must nonetheless have that power. See Hart, supra note 185, at 1401. Professor Hart's argument, like Chief Justice Marshall's in Marbury, runs through the Supremacy Clause, and thus would apply to application as well as existence conditions. The argument we present in the text is both less and more far-reaching. It is less far-reaching in that it would only bar Congress from waiving judicial enforcement of existence conditions, but more far-reaching in that where it does bar such a congressional waiver, it would require that the federal court itself decide whether the relevant existence condition is satisfied; congressionally mandated deference to, say, a state court determination of whether an existence condition were satisfied would only be permissible if the federal court thought, on epistemic or other grounds, that such double deference (first to Congress and then to the designated state court) would lead to the best understanding of the existence condition in question. Of course, our view is not especially far-reaching, falling, as it does, within the mainstream of views about the limits of congressional ability to direct judicial decisions by federal courts. See Akhil Reed Amar, A Neo-Federalist View of Article III: Separating the Two Tiers of Federal Jurisdiction, 65 B.U. L. Rev. 205, 206-09 (1985) (concluding that some federal court must be able to hear cases arising under federal law); Hart, supra note 185, at 1402 ("[J]urisdiction always is jurisdiction only to decide constitutionally."); Laurence $\mathbf{H}$. Tribe, Jurisdictional Gerrymandering: Zoning Disfavored Rights Out of the Federal Courts, 16 Harv. C.R.-C.L. L. Rev. 129 (1981) (arguing generally that congressional efforts to strip the federal courts of jurisdiction to resolve claims arising under particular constitutional doctrines violate such doctrines). For a useful summary of the case law and secondary literature on jurisdiction-stripping, see Note, Powers of Congress and the Court Regarding the Availability and Scope of Review, 114 Harv. L. Rev. 1551 (2001).
} 
terminations. Yet this perspectival character is a contingent feature of existence conditions, one that obtains only if the relevant text is sufficiently open-ended to admit a perspectival reading, other sources of constitutional interpretation support that reading, and so on. A genuine congressional power to waive judicial enforcement of existence conditions would make all conditions perspectival: It would mean that, for judicial purposes, all conditions are satisfied if Congress has so determined. We can find nothing in Article III, or any other part of the Constitution, that warrants a wholesale judicial deference to Congress as to what counts, constitutionally speaking, as law.

\section{CONCLUSION}

Chief Justice John Marshall argued in Marbury that the Constitution's status as higher law, combined with the judicial branch's obligation to say what the law is, conferred upon the courts a power and obligation to set aside laws inconsistent with the Constitution. Marshall's argument has long been criticized as questionbegging: Why should the courts assume that they are better positioned to interpret the Constitution than other actors, especially Congress?

We have argued here that the judiciary's power to say what the law is does indeed entail the power and duty to set aside unconstitutional laws, but for a different, and in some sense a more modest, set of reasons than those offered by Marshall. Courts are frequently called upon to apply nonconstitutional law such as statutes. One can imagine a legal system in which the constitution plays no role in identifying what propositions have the status of nonconstitutional law, but in the actual U.S. legal system, many of the existence conditions for nonconstitutional law are contained in the Constitution. Moreover, many of the most familiar constitutional provisions and doctrines-including separation-of-powers, most federalism, and many individual rights provisions and doctrinesset forth existence conditions. Accordingly, the courts' obligation to apply nonconstitutional law entails an obligation to "enforce" the Constitution. Even if Marshall's argument is disregarded, the Constitution simply cannot be taken away from the courts.

Our argument is largely consistent with doctrines-such as the enrolled bill doctrine, the political question doctrine, and rational 
basis review-that appear to grant Congress (or other actors) complete or partial deference with respect to the proper interpretation of existence conditions. In some of these cases, the best judicial interpretation of the relevant existence condition gives Congress (or some other actor) deference on epistemic grounds. In others, the relevant existence condition may be "perspectival," addressing one command to Congress (or some other actor) and another to the courts.

Consistency with existing doctrine is not, of course, the whole story. To the extent that a proposal to make various parts of the Constitution nonjusticiable is a proposal for constitutional amendment, it aims to reform existing doctrine. It is crucial to understand just how sweeping such an amendment would be. A constitutional amendment precluding enforcement of one or another constitutional existence condition effectively transforms that provision into an application condition. It thereby changes what counts as law for purposes of ordinary, nonconstitutional adjudication. For some existence conditions, an amendment of this sort is imaginable, if perhaps inadvisable. But a radical amendment precluding the enforcement of any constitutional existence conditions (or other provisions) borders on the incoherent. How could one tell whether an utterance is a statute, or just the deontic ravings of a lunatic, except by reference to Article I, Section 7 ? Such a radical amendment is conceivable only if packaged with a change in our legal culture-namely, one in which a sufficient range of existence conditions for federal law are provided extraconstitutionally. Proponents of taking the Constitution away from the courts have yet to grapple with this issue, let alone provide a concrete proposal for "amending" the U.S. legal culture in the manner required. Formal constitutional amendments alone would not do the trick. ${ }^{247}$

\footnotetext{
${ }^{247}$ We argued in Part II that the question whether a particular constitutional proposition is an existence condition or an application condition is itself a question of constitutional law rather than extraconstitutional law. Why then, wouldn't a simple constitutional amendment be sufficient to convert all existence conditions into application conditions? The answer is that once the constitutional provisions themselves lose their status as existence conditions, in order to fill the legal void, some other-extraconstitutional-criteria would need to be found through which to identify the law. By definition, however, extraconstitutional criteria cannot be established through a constitutional amendment.
} 